\title{
EVAPOTRANSPIRAÇÃO E DESENVOLVIMENTO DE LIMEIRA ÁCIDA 'TAHITI' NA AUSÊNCIA E PRESENÇA DE ESTRESSE HÍDRICO
}

\section{CLÁUdIO RICARDO DA SILVA}

\author{
Tese apresentada à Escola Superior de Agricultura \\ “Luiz de Queiroz”, Universidade de São Paulo, para \\ obtenção do título de Doutor em Agronomia, Área de \\ Concentração: Irrigação e Drenagem
}

P I R A C I C A B A

Estado de São Paulo - Brasil

Junho - 2005 


\title{
EVAPOTRANSPIRAÇÃO E DESENVOLVIMENTO DE LIMEIRA ÁCIDA 'TAHITI' NA AUSÊNCIA E PRESENÇA DE ESTRESSE HÍDRICO
}

\author{
CLÁUDIO RICARDO DA SILVA \\ Engenheiro Agrônomo
}

Orientador: Prof. Dr. MARCOS VINÍCIUS FOLEGATTI

Tese apresentada à Escola Superior de Agricultura

“Luiz de Queiroz”, Universidade de São Paulo, para obtenção do título de Doutor em Agronomia, Área de Concentração: Irrigação e Drenagem

P I R A C I C A B A

Estado de São Paulo - Brasil

Junho - 2005 
Dados Internacionais de Catalogação na Publicação (CIP) DIVISÃO DE BIBLIOTECA E DOCUMENTAÇÃO - ESALQ/USP

\section{Silva, Cláudio Ricardo da}

Evapotranspiração e desenvolvimento e limeira ácida 'Tahiti' na ausência e presença de estresse hídrico / Cláudio Ricardo da Silva. - - Piracicaba, 2005.

85 p. : il.

Tese (doutorado) - - Escola Superior de Agricultura Luiz de Queiroz, 2005. Bibliografia.

1. Condutância estomática 2. Desenvolvimento vegetal 3. Estresse hídrico 4. Evapotranspiração 5. Fruta cítrica 6. Irrigação 7. Variação sazonal I. Título 
"You can fight

Without ever winning

But never ever win

Without a fight”

(Alex, Lee, Lifeson - Rush) 


\section{AGRADECIMENTOS}

Este trabalho, apesar de ser a concretização de um sonho, apenas resume o que foram os 42 meses do meu Doutorado. Foi uma experiência fantástica morar em Piracicaba, estudar na ESALQ, desenvolver e testar as hipóteses da minha tese com acertos e erros bem como, conhecer e compartilhar informações com pessoas de outras regiões e cultura diferentes. Muitas foram às atividades desenvolvidas mas o fato é que se não fosse a ajuda de inúmeras pessoas este objetivo nunca poderia ser alcançado.

A DEUS pelo seu amor incondicional, que nos torna vivos e cheios de alegria e felicidade, prontos a encarar qualquer desafio.

Gostaria de agradecer os meus pais, Cláudio José da Silva e Elza Cerqueira da Silva e a minha irmã, Cristina Mara da Silva, por todo amor que recebo.

A Elaine Cristina de Matos, pelos nossos anos de ótimo relacionamento.

Meu agradecimento especial ao prof. Dr. Marcos Vinícius Folegatti, pela sua confiança no projeto, por seus conselhos, apoio incansável e bom humor.

Gostaria de agradecer ao professor Dr. Luis Fernando de Souza Magno Campeche, pelas suas dicas valiosas e ensinamentos sobre lisimetria e "data loggers".

A minha gratidão aos professores: Dr. Rubens Duarte Coelho, pelo empréstimo da câmara de pressão; Dr. Carlos Guilherme Silveira Pedreira (Deptartamento de Zootecnia), pelo empréstimo do IRGA; Dr. Claudinei Fonseca Souza e Dr. Edson Eiji Matsura (UNICAMP) pelos ensinamentos da técnica de TDR e empréstimo do 
equipamento e ao Dr. Ricardo Ferraz de Oliveira (Departamento de Ciências Biológicas) pelas suas valiosas dicas e por permitir o uso do laboratório.

Ao prof. Dr. Fernando Braz Tangerino Hernandez, pelo seu modelo de profissionalismo, liderança e por seus incentivos incansáveis.

Aos meus amigos e co-orientadores: José Alves Júnior e Dr. Tonny José Araújo da Silva pela agradável convivência e excelente parceria.

A Rafael Vasconcelos Ribeiro (Pesquisador científico do IAC), Dr. Roberto Terumi Atarassi e Dr. Nildo da Silva Dias pelas dicas valiosas e orientação.

Aos professores: Dr. Sérgio Duarte Nascimento, Dr. José Antonio Frizzone, Dr. Antonio Roberto Pereira (Departamento de Ciências Exatas), pelos ensinamentos.

Aos meus amigos orientados e ex-orientados do professor Marcos Vinícius Folegatti: Anamaria de Souza Duarte, Ariovaldo Antonio Tadeu Lucas, Célia Regina Ferrari Faganello, Dr. Edivaldo Casarini, Dr. Ênio Farias de França e Silva, Flávio Flavaro Blanco, Ronaldo Antônio dos Santos, Dr. René Porfírio Camponez do Brasil, Vinícius Maia Costa e Roberta Alessandra Bruschi Gonçalves, pela nossa união e parceria.

Aos colegas do curso de Pós-Graduação em Irrigação e Drenagem: Adriana Lúcia da Silva, Antonio Clarette Santiago Tavares, Boanerges Siqueira d’Albuquerque Júnior, Carmello Crisafulli Machado, Dennis César Cararo, Guilherme Busi de Carvalho, Jocelito Saccol de Sá, Marco Antonio Jacomazzi, Patrícia Angélica Alves Marques, Ralini Ferreira de Melo, Rodrigo Otávio Rodrigues de Melo Souza, Ruben Alcides Franco Ibars, Tales Miler Soares, Yanê Borges Garcia Gruber, Wulf Schmidt, pela agradável convivência.

Aos funcionários do Departamento: Lino Stênico, Hélio de Toledo Gomes, Gilmar Batista Grigolon Dalvimar Aparecida D. Colevatti e Sandra Regina T. Silveira Mello pelo grande suporte recebido. 
As secretárias da Prefeitura do campus da ESALQ: Beatriz Regina Duarte Novaes, Márcia Cristina Guidi Ganzella, Maria Estela Trimer de Oliveira Bigotto, Márcia Maria Fecchio, Roseli Cappelletti, pela ajuda recebida.

Aos estudantes do GPID, representado na pessoa de Fábio Jordão Rocha pela ajuda na obtenção de dados e convivência.

Aos meus amigos de moradia: Márcio Aurélio Lins dos Santos, Valdomiro Severino de Souza Júnior, Fernando Alves de Azevedo, Hector Alonso San Martin Matheis, Miguel Ferreira Neto e Jovan de Jesus, pela convivência agradável.

Por fim gostaria de lembrar a minha saudosa cachorra rottweiler "Xena" (in memoriam) que me acompanhou aqui durante três anos. 


\section{SUMÁRIO}

Página

RESUMO

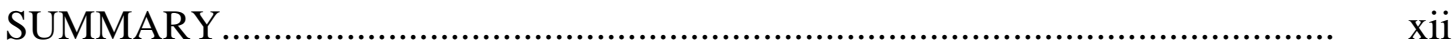

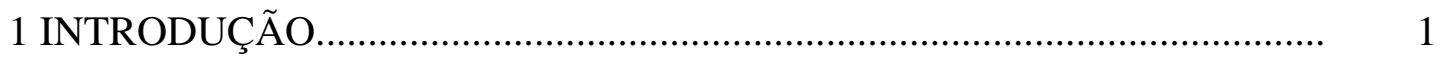

2 REVISÃO DE LITERATURA............................................................. 4

2.1 Fisiologia das plantas cítricas e estresse hídrico.......................................... 4

2.2 Manejo de irrigação em citros.................................................................... 15

2.3 Evapotranspiração das plantas cítricas.......................................................... 20

3 VARIAÇÃO SAZONAL NA EVAPOTRANSPIRAÇÃO DE PLANTAS JOVENS DE LIMEIRA ÁCIDA 'TAHITI..................................................... 22

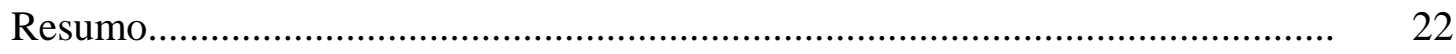

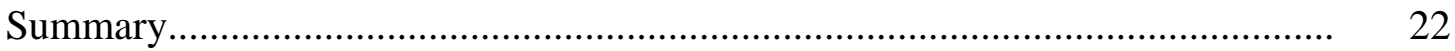

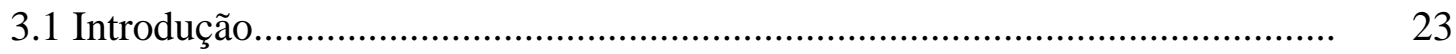

3.2 Material e Métodos................................................................................. 24

3.3 Resultados e Discussão....................................................................... 28 


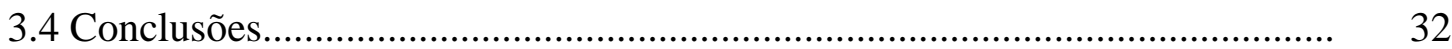

4 LIMITE CRÍTICO DA ÁGUA DISPONÍVEL NO SOLO PARA A EVAPOTRANSPIRAÇÃO, TROCAS GASOSAS E POTENCIAL DE ÁGUA NA FOLHA EM LIMEIRA ÁCIDA 'TAHITI' SOB CONDIÇÕES DE CAMPO

Resumo

Summary

4.1 Introdução...............................................................................................

4.2 Material e Métodos....................................................................................

4.3 Resultados e Discussão..................................................................................

4.4 Conclusões...............................................................................................

5 RESPOSTAS DE LIMEIRA ÁCIDA 'TAHITI' A SUPRESSÃO DA IRRIGAÇÃO DURANTE DIFERENTES PERÍODOS FENOLÓGICOS......................................................................................... 55

Resumo

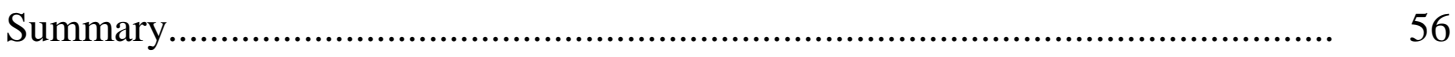

5.1 Introdução..................................................................................................

5.2 Material e Métodos....................................................................................... 58

5.3 Resultados e Discussão................................................................................... 62

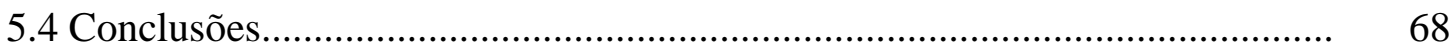




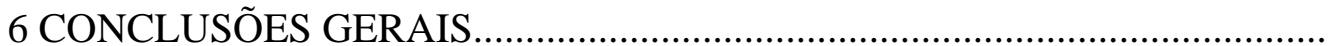

REFERÊNCIAS BIBLIOGRÁFICAS........................................................ 71 


\title{
EVAPOTRANSPIRAÇÃO E DESENVOLVIMENTO DE LIMEIRA ÁCIDA 'TAHITI’ NA AUSÊNCIA E PRESENÇA DE ESTRESSE HÍDRICO
}

\author{
Autor: CLÁUDIO RICARDO DA SILVA \\ Orientador: Prof. Dr. MARCOS VINÍCIUS FOLEGATTI
}

\section{RESUMO}

As relações hídricas e fisiológicas em plantas de lima ácida 'Tahiti' sob estresse hídrico foram estudadas tendo-se como principais objetivos: (a) verificar a sazonalidade da evapotranspiração e o coeficiente de cultivo com o uso de lisímetro de pesagem baseado em célula de carga eletrônica, (b) determinar o limite crítico da água disponível em função da evapotranspiração, trocas gasosas e potencial de água na folha durante um período de estresse hídrico e (c) avaliar o efeito da supressão da irrigação durante diferentes períodos fenológicos sobre o desenvolvimento vegetativo, na produtividade e qualidade do fruto. Este experimento foi conduzido na Fazenda Areão do Departamento de Engenharia Rural da ESALQ/USP, em Piracicaba, SP, em um pomar de 1 hectare no espaçamento de 7 X 4 m com lima ácida 'Tahiti’ (Citrus latifolia Tanaka) enxertadas em citrumelo 'Swingle' [Poncirus trifoliata (L.) Raf. x C. paradisi Macf.] irrigadas por gotejamento. Para as medidas fisiológicas, foram utilizados equipamentos portáteis como a câmara de pressão e analisador de gases por infravermelho além de medidas do desenvolvimento vegetativo e produtivo. O monitoramento da água solo foi realizado por tensiômetros e sondas de TDR. A Evapotranspiração de Referência foi obtida com uma estação agrometeorológica automatizada presente na área. Verificou-se um efeito sazonal na evapotranspiração, com uma redução superior a 50\% no período verãoinverno, possibilitando a economia da irrigação no período. A evapotranspiração, trocas 
gasosas e potencial da água na folha ao amanhecer foram diminuídos pelo esgotamento de $40 \%$ da água disponível do solo por ocasião do final do período de inverno. A supressão da irrigação no período de Setembro a Março diminuiu o potencial matricial do solo e promoveu um estresse leve nas plantas não-irrigadas, não se observando efeitos negativos no desenvolvimento vegetativo, produtivo e na qualidade dos frutos formados. Recomenda-se o potencial da água no folha ao amanhecer para manejo da irrigação, mantendo-o maior que -0,6 MPa, para evitar o estresse hídrico em plantas de limeira ácida 'Tahiti'. 


\title{
EVAPOTRANSPIRATION AND GROWTH OF 'TAHITI' ACID LIME TREES IN ABSENCE AND PRESENCE OF WATER STRESS
}

\author{
Author: CLÁUDIO RICARDO DA SILVA \\ Adviser: Prof. Dr. MARCOS VINÍCIUS FOLEGATTI
}

\section{SUMMARY}

Water and physiologic relations in acid lime trees under water stress were studied with the following purposes: (a) to verify the seasonal effect of evapotranspiration and the crop coefficient in non-stressed trees by weighing lysimeter; (b) to determine the critical soil water depletion for evapotranspiration, gas exchange as well as the leaf water potential during a stage of growing of the trees and (c) to determine the effect of the irrigation suppression on growth, yield and fruit quality during different phenological periods. The experiment was carried out an experimental farm at College of Agriculture Luiz de Queiroz (ESALQ), in Piracicaba and performed from 2003 to 2005 in a 1 hectare orchard planted with 'Tahiti' (Citrus latifolia Tanaka) grafted on 'Swingle' [Poncirus trifoliata (L.) Raf. x C. paradisi Macf. ] rootstock. The trees were spaced 7 x 4 m apart and drip-irrigated. For physiologic measurements were used portable equipments such as a pressure chamber and an infrared gas analyzer as well measurements of vegetative and productive growth. The soil water status was monitored by tensiometers and TDR probes. The reference evapotranspiration was obtained by an automatic weather station presented on the area. There was a seasonal effect on evapotranspiration with a reduction higher than $50 \%$ forward to summer-winter, being 
able to water savings in the period. The evapotranspiration, gas exchange and leaf water potential at predawn were decreased when the soil water available was depleted by $40 \%$ in the end of winter. The irrigation suppression from September and March decreased the soil matric potential and promoted a light stress level in non-irrigated trees, but without negative effects on vegetative, productive and fruit quality. We recommend the leaf water potential at predawn for irrigation scheduling, keeping higher than -0.6 MPa for avoid water stress in acid lime trees. 


\section{INTRODUÇÃO}

"A cultura do citros está quase que universalmente prejudicada por intempéries climáticas e doenças...novas pragas e doenças emergem e estão sendo disseminadas...as pressões por mudanças em cultivares, porta-enxertos e práticas culturais são grandes” (Spiegel-Roy \& Goldschimidt, 1996, p.2).

Profundas modificações no sistema de cultivo têm levado a irrigação a assumir um novo papel na citricultura. Anteriormente recomendada para aumento de produtividade, atualmente pode possibilitar a antecipação do florescimento e a manutenção da produtividade de pomares formados com porta-enxertos menos tolerantes ao déficit hídrico. O interesse do citricultor na técnica tem sido crescente.

Paralelamente, o custo da irrigação tem fomentado a utilização de métodos de irrigação que maximizem sua eficiência de uso dos recursos hídricos. Nesse contexto a irrigação localizada, principalmente o gotejamento, tem assumido importante papel na redução do volume de água aplicado. Entretanto, a máxima eficiência na irrigação é dependente do manejo, cuja praticabilidade e melhoria faz-se necessário.

O primeiro passo para o manejo racional da irrigação se refere ao conhecimento da evapotranspiração da cultura (ETc) e do coeficiente de cultivo (Kc) uma vez que essa é uma informação primordial para se outorgar e dimensionar os sistemas de irrigação. A Organização Alimentar e Agrícola (FAO) em seu boletim 56 (Allen et al., 1998) sugere valores médios de Kc para citros ao longo do ano. Tal informação tem sido constantemente utilizada pelos técnicos e projetistas brasileiros. No entanto, em nossas condições edafoclimáticas, até que ponto estes valores são adequados? 
As metodologias mais comumente empregadas para manejo de irrigação baseiamse no conhecimento da umidade da água no solo (seja em termos do conteúdo de água, porcentagem da água disponível ou potencial da água no solo). Estes limites, normalmente são estabelecidos através de experimentos de longa duração, comparandose a produtividade ou dados de crescimento da planta em determinado nível de umidade para uma região e tipo de solo. Davies \& Albrigo (1994) comentam que a análise de parâmetros fisiológicos tais como condutância estomática, potencial da folha ou fruto e assimilação de $\mathrm{CO}_{2}$ é fundamental para melhor compreensão dos fatores que limitam a produtividade e/ou crescimento das plantas.

As plantas cítricas reduzem a evapotranspiração automaticamente quando a água do solo começa a ficar menos disponível às raízes (Castel \& Buj, 1990; Sepaskhah \& Kashefipour, 1995 e Ginestar \& Castel, 1996). A condutância estomática e assimilação de $\mathrm{CO}_{2}$ também são reduzidas (Davies \& Albrigo, 1994 e Syvertsen \& Lloyd, 1994). Diversos estudos têm relatado as respostas fisiológicas de laranjeiras à deficiência hídrica do solo (Medina et al., 1998 e Machado et al., 1999), no entanto, quantos são os trabalhos que consideram os estudos fisiológicos aliados ao sistema de irrigação em condições de campo?

Devemos irrigar então visando a máxima condutância estomática e conseqüentemente a máxima evapotranspiração? É do conhecimento de todos que a manutenção de um leve estresse hídrico pode melhorar a partição de carboidratos na direção das estruturas reprodutivas e controlar o excessivo crescimento vegetativo. Chalmers et al. (1981) propôs uma estratégia de irrigação baseada na imposição de um déficit controlado de irrigação (RDI) em períodos fenológicos que não são prejudiciais à produtividade da cultura. Para tanto, faz-se necessário o conhecimento dos efeitos da supressão hídrica nos diferentes períodos fenológicos sob condições edafoclimáticas locais.

Diante do exposto, está claro que o manejo racional da irrigação depende dos objetivos do irrigante. No entanto, independentemente da estratégia a ser utilizada é 
fundamental reunir o máximo de informações sobre o comportamento da planta frente à irrigação.

Por último, apesar do Brasil figurar como o maior produtor mundial de citros, ainda são poucos os trabalhos realizados dedicados à irrigação, comparativamente aos Estados Unidos e Espanha, segundo e terceiro maiores produtores, respectivamente.

Nesse contexto, este trabalho teve como objetivos principais:

a) determinar a variação sazonal da evapotranspiração e coeficiente de cultivo de limeira ácida ‘Tahiti’ com o uso de lisímetro de pesagem baseado em célula de carga;

b) analisar o comportamento da evapotranspiração, condutância estomática e assimilação de $\mathrm{CO}_{2}$ a partir da diminuição da água disponível do solo, durante um período de déficit hídrico;

c) avaliar o efeito da supressão hídrica durante diferentes períodos fenológicos sobre o desenvolvimento da planta, produtividade e qualidade do fruto de limeira ácida 'Tahiti'. 


\section{REVISÃO DE LITERATURA}

\subsection{Fisiologia das plantas cítricas e estresse hídrico}

As relações hídricas no citros são influenciadas por uma extensa resistência ao transporte de água dentro da planta. Esta resistência pode estar associada, pelo menos em parte, a baixa presença de ramos e ao pouco desenvolvimento do sistema radicular, que apesar de serem abundantes apresentam baixa condutividade hidráulica (Kriedemann \& Barrs, 1981). Isso resulta em potenciais de água na folha menores mesmo em condições de bom nível de umidade do solo comparativamente com outras espécies de plantas perenes. Outra característica do citros é a sensibilidade de seus estômatos à umidade relativa do ar, a qual pode estar também correlacionada com essa resistência interna.

As folhas de citros estão adaptadas a conservar a água. A vida de uma folha pode ser de 9 meses a mais de 2 anos (Kriedemann \& Barrs, 1981). Durante o período de expansão as folhas apresentam uma coloração verde-clara, de textura leve e, secam imediatamente quando retirada do ramo. Adquirem competência fotossintética lentamente somente exportando assimilados ou nutrientes quando todas as folhas do ramo estão completamente desenvolvidas. Por ocasião da maturação tornam-se verdeescuras, com textura firme não secando quando retiradas do ramo imediatamente. A máxima taxa fotossintética (4-8 $\mu \mathrm{mol} \mathrm{CO}_{2} \mathrm{~m}^{-2} \mathrm{~s}^{-1}$ ) é obtida quando as folhas estão com 3 a 4 meses e tem sido observado algum declínio na taxa em folhas com mais de 6 meses (Kriedemann \& Barrs, 1981). Medina (2003) cita que em laranjeiras sadias a máxima assimilação situa-se próximo a $12 \mu \mathrm{mol} \mathrm{CO} \mathrm{CO}^{-2} \mathrm{~s}^{-1}$. Para Taiz \& Zeiger (2004) o efeito relativo do estresse hídrico é maior sobre a condutância estomática do que na taxa 
fotossintética, uma vez que o fechamento estomático inibe a transpiração mais do que diminui as concentrações intercelulares de $\mathrm{CO}_{2}$.

Associado a expansão foliar vem o aumento da suberização das superfícies internas e da cutícula que auxiliam na diminuição da transpiração, pelo fechamento dos estômatos. Estas mudanças podem explicar a observação que a resistência à perda de água é consideravelmente menor em folhas jovens e maior em folhas mais velhas (Kriedemann \& Barrs, 1981). A senescência da folha é terminada com o desprendimento da folha na zona de abscisão na base do pecíolo depois da remoção de constituintes trocáveis, porém uma segunda zona de abscisão pode ocorrer entre a lamina foliar e o pecíolo o qual permite uma rápida excisão da folha sob condição de severo estresse, visando à diminuição rápida da transpiração. A ocorrência de duas zonas de abscisões, uma das quais aparentemente é mais sensível a perda de água do que a outra parece ser a teoria mais consistente da capacidade adaptativa de citros a condição de seca (Kriedemann \& Barrs ,1981).

A taxa fotossintética também é sazonal. Machado et al. (2002) encontraram que há uma diminuição no sentido de janeiro a junho, possivelmente relacionadas tanto à queda de temperatura noturna quanto à queda na atividade de crescimento da planta. Já durante o dia, também se verifica a ocorrência de uma depressão da taxa de assimilação associada ao aumento do déficit de pressão de vapor de água no ar, que é maior com o aumento da temperatura nas horas de maior radiação solar. Este efeito é mais pronunciado quanto menor for a quantidade de água no solo.

Sabe-se que as plantas cítricas saturam-se com valores baixos de irradiação solar, cerca de 600 a $700 \mu \mathrm{mol} \mathrm{m} \mathrm{m}^{-2} \mathrm{~s}^{-1}$ segundo Spiegel-Roy \& Goldschmitdt (1996), sendo esse valor superado facilmente em dias ensolarados. Entretanto, esse nível de saturação de radiação ocorre apenas nas folhas da margem externa da copa e somente em uma parte do dia recebem essa radiação. Mesmo assim as folhas apresentam um mecanismo de controle para evitar o excesso de radiação incidente, pois em certos dias claros e quentes é comum encontrar folhas, principalmente as expostas marginalmente, enroladas 
em volta da nervura principal por longos períodos do dia. Green \& Gerber (1967) citados por Spiegel-Roy \& Goldschmitdt (1996) encontraram que a copa de uma planta adulta pode reduzir em $90 \%$ a radiação direta e de 20 a 50 \% a radiação difusa a 1 metro de profundidade da margem devido a seu elevado índice foliar.

A temperatura da folha exposta à radiação solar é normalmente maior do que a temperatura do ar no meio do dia, mesmo durante os períodos de máxima condutância. Já as folhas sombreadas acompanham a temperatura do ar indicando que o resfriamento via transpiração é insuficiente para reduzir a temperatura da folha (Syvertsen \& Lloyd, 1994).

A maior parte dos estômatos está localizada na parte inferior da folha. Ehrler \& Bavel (1968) mediram 800 por $\mathrm{mm}^{-2}$ sobre a face inferior e $40 \mathrm{~mm}^{-2}$ na face superior em limão. Enquanto Spiegel-Roy \& Goldschmitdt (1996) citam de 400 a $700 \mathrm{~mm}^{-2}$ na face inferior. Esta densidade é variável em função da variedade, tamanho e posição da folha na planta. Esta alta densidade de estômatos poderia potencializar uma rápida transpiração, entretanto, a rede de vasos na primeira e segunda ordem nas folhas é pouco desenvolvida quando comparada com outras plantas perenes como Vitis vinifera (Kriedemann \& Barrs, 1981). Além disso, apesar de estarem em um número comparativamente elevado, os poros são relativamente menores quando comparado com outras plantas perenes, conforme vários trabalhos citados por Kriedemann \& Barrs (1981). O controle estomático à perda de água é baixo em folhas novas, mas torna-se eficiente em folhas maduras (Syvertsen, 1982).

Quanto ao sistema radicular dos citros, além da baixa condutividade das suas raízes, que varia em função da temperatura e do porta-enxerto utilizado, as raízes se encontram superficialmente no perfil do solo. Rodriguez et al. (1978) fizeram amostragens de raízes aos 3, 6, 12, 24 e 36 meses de idade com os seguintes portaenxertos: limoeiro 'Cravo', laranja 'Caipira' e Poncirus trifoliata, e verificaram que 80 a 90\% das raízes se encontravam até 0,5 m de profundidade. Alves Júnior et al. (2004) verificaram que, em plantas jovens (30 meses) de limeira ácida 'Tahiti' irrigadas por 
gotejamento, as raízes se concentravam na profundidade de 0 a $0,3 \mathrm{~m}$ e a $0,6 \mathrm{~m}$ do caule lateralmente. Enquanto que para plantas adultas, Montenegro (1960) verificou que 90\% das raízes atingiram até $0,6 \mathrm{~m}$ de profundidade para árvores de 10 anos e até 0,9 m em plantas de 23 anos. Moreira (1983) estudando o sistema radicular em plantas de 7 anos, constatou que $60 \%$ das raízes se encontravam a $0,3 \mathrm{~m}$ de profundidade e $73 \%$ das raízes até 0,6 m. Pires (1992), para fins de irrigação, recomenda considerar 0,6 m como profundidade efetiva das raízes em pomares em produção e 0,5 m em viveiros.

No entanto, como ressalva devemos observar que o domínio e a distribuição do sistema radicular das culturas cítricas, da mesma forma que de outras culturas, depende das características físicas do solo, em especial da textura e estrutura, dos fatores genéticos, do teor de água do solo, que atua na resistência do solo à penetração das raízes (Klepper, 1987). Coelho et al. (2002) estudando o comportamento do sistema radicular de laranja 'Pera' sob irrigação por microaspersão e sequeiro sob solo arenoso, encontraram que a distribuição das raízes em profundidade foi mais uniforme na microaspersão do que nas áreas não irrigadas ( 0 a $0,7 \mathrm{~m})$, indicando que a irrigação melhorou a distribuição da água no perfil do solo, em especial no período seco contribuindo para uma maior expansão em profundidade e em distância radial do tronco do que sob condições não-irrigadas. Santos et al. (2002) avaliando a distribuição do sistema radicular da lima ácida 'Tahiti' enxertada com citrumelo 'Swingle' sob microaspersão no semi-árido Baiano e em solo de textura média, encontraram que a profundidade efetiva das raízes foi de 0,25 m, com distancia efetiva de 1,0 m, sugerindo serem estas as medidas mais adequadas para a instalação de sensores para monitoramento da água do solo, visando o manejo da irrigação.

O desenvolvimento e crescimento do sistema radicular e da parte aérea são interdependentes, ou seja, a limitação de um, resulta em restrição a outro. Tanto que uma desfolha da parte área é seguida por uma considerável morte de raízes (Castro et al., 2001). O cessamento do crescimento das raízes também foi relatado por Monselise (1985) e Volpe (1992) quando ocorre o estresse por deficiência hídrica e por baixas temperaturas favorecendo o florescimento. 
Em geral, as plantas cítricas desenvolvem-se em regiões de clima subtropical, quando as baixas temperaturas no inverno induzem a uma dormência e a um período de diferenciação floral seguido de um intenso florescimento na primavera. A duração do período de florescimento é largamente dependente da temperatura. Sob condições de clima mais quente as flores se abrirão dentro de poucos dias, resultando em um surto concentrado de flores abertas, queda e pegamento de frutos, entretanto, sob condições de temperaturas amenas o período pode se estender, obtendo-se um florescimento difuso (Spiegel-Roy \& Goldschmidt, 1996).

Segundo Krajewski \& Rabe (1995) os principais fatores endógenos e exógenos que são relatados na literatura a influenciar o florescimento em citros são: fotoperíodo, temperatura, estresse hídrico, metabolismo do nitrogênio, carboidratos, nutrição mineral, hormônios vegetais, retardadores de crescimento e presença ou ausência de fruto.

Southwick \& Davenport (1987) relatam que o fotoperíodo parece não influenciar significativamente o florescimento dessas plantas. No entanto, o crescimento vegetativo e o alongamento dos ramos são favorecidos por dias longos (Spiegel-Roy \& Goldschmidt, 1996).

Para Albrigo et al. (2002), para o frio atuar isoladamente e promover o florescimento, há necessidade de pelo menos 750 horas de temperaturas abaixo de $20{ }^{\circ} \mathrm{C}$. Recentemente, Valiente \& Albrigo (2004), na Flórida, encontraram que a máxima intensidade de florescimento para laranjeiras 'Valencia' e 'Hamilin' ocorreu quando houve um acúmulo de temperaturas na faixa de 11 a $15^{\circ} \mathrm{C}$ (>300 h).

O estresse hídrico parece ser o maior fator indutor nas condições tropicais. Segundo Pire et al. (1993), o florescimento é influenciado naturalmente pela sucessiva ocorrência de período de chuva e seca. Na Itália, o estresse hídrico durante o verão é uma prática comum para indução floral na cultura do limão e uma vez ocorrido o florescimento é igualmente importante a manutenção de uma quantidade adequada de água disponível no solo (Barbera, 1985 citado por Pire et al., 1993). 
Em diversas fruteiras, para se obter uma produção fora de época, tem-se tentado modificar o período de floração mediante diversos métodos, porém segundo Chaikiattiyos et al. (1994) a indução por estresse hídrico é a mais eficiente. Um prolongado moderado estresse hídrico promove o florescimento dos citros (Abbott, 1935; Cassin et al., 1969; Nir et al., 1972 e Southwick \& Davenport, 1987).

Medina (2003) recomenda que para a indução de florescimento satisfatório, a seca deve ter intensidade e duração suficiente para conduzir a uma visível perda de hidratação das folhas (murcha) por um período próximo de 40 dias sem que haja desfolha excessiva e prejudicial à planta.

Southwick \& Davenport (1987) trabalhando com a lima ácida 'Tahiti' em condições de ambiente controlado, avaliaram os efeitos da temperatura e estresse hídrico sobre o florescimento, encontraram que um severo estresse (-3,5 MPa de potencial da água na folha) por quatro ou cinco semanas foi suficiente para induzir um significante florescimento. Já o estresse causado pelas baixas temperaturas $\left(18 / 10^{\circ} \mathrm{C}\right.$ dia e noite) promove a indução, porém o efeito corresponde como a um estresse hídrico moderado. Além disso, concluíram que a poda ou desfolha não é essencial para a indução floral.

Segundo Lovatt et al. (1988), em laranja e limão o estresse hídrico e as baixas temperaturas provocam uma acumulação de produtos nitrogenados como a amônia e que se correlaciona positivamente com a floração. Ainda segundo o autor, a quantidade de amônia presente na folha não atua diretamente a iniciação floral, porém, serve como um substrato para a síntese de metabólitos chaves, que atuam a nível genético para iniciar o processo de florescimento.

Novos experimentos foram propostos para avaliar o efeito da aplicação foliar de produtos nitrogenados, basicamente uréia, visando aumentar a intensidade do florescimento, especialmente quando o estresse hídrico não é suficiente para provocar a indução. No entanto, a maioria das respostas não foi positiva, possivelmente devido à época de aplicação e dosagem (Albrigo, 1999). Pire \& Rojas (1999), procurando 
avaliarem condições de campo, na Venezuela, o efeito do estresse hídrico e aplicação de uréia sobre a produção de flores em lima ácida 'Tahiti', encontraram que o florescimento aumentou com os níveis de estresse significativamente, mas não houve resposta para a aplicação de uréia a 5\%. Comentaram também que as limeiras estão bem adaptadas à condição de clima tropical e tendem a responder de forma melhor ao estresse do que as laranjeiras, como verificado no trabalho de Pire et al. (1993).

Albrigo (1999) encontrou que a aplicação de uréia (28-30 $\mathrm{kg} \mathrm{ha}^{-1}$ ) no inverno (período de indução), aumentou significativamente a produtividade e o conteúdo de sólidos solúveis totais nos frutos de laranjeira 'Valencia' após 4 anos de uso regular, na Flórida.

A competição pelas reservas em carboidratos pode limitar a formação de gemas florais (Ruiz \& Guardiola, 1994 e Spiegal-Roy \& Goldschmidt, 1996). Depois que a diferenciação floral se inicia, as plantas podem não ser capazes de translocar quantidades suficientes de (N, P, K) para suprir sua produção 50.000 a 100.000 flores por planta (Erickson \& Brannaman, 1960) O estado nutricional da planta pode influenciar o número de flores e o pegamento (Albrigo, 1999). Teores de N, P e K de folhas velhas durante o período de florescimento e pegamento foram reduzidos juntamente com um aumento nesses nutrientes em folhas e frutos jovens (Ruiz \& Guardiola, 1994).

A influência dos hormônios vegetais no florescimento dos citros foi revisada por Davenport (1990). De todos os hormônios estudados somente a giberelina parece ter uma consistente influência no florescimento. Pequenas variações nos níveis de giberelina podem determinar a morfologia dos tipos de brotações e manter o balanço entre crescimento vegetativo e reprodutivo (Castro et al., 2001).

Para Spiegal-Roy \& Goldschmidt (1996) supõe-se que as raízes em crescimento sejam o principal local de síntese de giberelinas e, portanto, em condições de baixa temperatura e/ou déficit hídrico que levam ao cessamento do crescimento das raízes pode existir uma redução do suprimento de giberelina para a parte aérea. Tal suposição 
pode explicar o mecanismo pelo qual o frio ou o estresse hídrico induz o florescimento em citros.

Aplicações exógenas de ácido giberélico, durante o período de repouso de algumas espécies cítricas, resultam em inibição do florescimento primaveril (Castro et al., 2001). Dando suporte a essa teoria, foi estabelecida uma ligação entre fatores abióticos promotores do florescimento e os níveis de giberelina (Castro et al., 2001). Tanto o estresse hídrico quanto a exposição a baixas temperaturas reduz os níveis endógenos de giberelinas (Tamin et al., 1997).

Castro et al. (2001) comenta que tratamentos a base de ácido giberélico podem ser utilizados para corrigir a improdutividade daquelas variedades cuja elevada intensidade de floração compromete a fixação como também, para melhorar a qualidade do fruto daquelas variedades de maior valor comercial sendo, portanto, desejável uma intensidade média de floração.

Assumindo que giberelina endógena e exógena atuem como inibidores do florescimento, então inibidores da síntese de giberelina (retardadores do crescimento) podem promover o florescimento dos citros (Spiegal-Roy \& Goldschmidt, 1996). Destes se destacam o paclobutrazol. A resposta à sua aplicação tem sido variável em função de uma série de fatores como práticas culturais e época de aplicação (Spiegal-Roy \& Goldschmidt, 1996). Davenport (1990) comenta que são escassos os trabalhos relatando aumento do florescimento com paclobutrazol sob condições não-indutivas ambientais.

Embora, a giberelina seja o principal hormônio que atua no florescimento é provável que outros hormônios como a citocinina, auxina e ácido abscísico também exerçam influência, entretanto, apenas de forma indireta, na brotação, na dominância (uma vez que existe um gradiente floral) e inibição de ramos generativos, respectivamente (Krajewski \& Rabe, 1995).

A presença do fruto influi na intensidade do florescimento. Southwick \& Davenport (1987) verificam o efeito da presença ou ausência e tamanho do fruto no 
florescimento e concluíram que a presença e o tamanho do fruto inibiram a produção de ramos como também a expressão floral. Segundo Moss (1971), a influência do fruto na planta é tão importante que ramos que têm frutos não florescem ou fazem com intensidade muito baixa e sugerem a eliminação precoce do fruto para aumentar a floração do ano seguinte.

Medina (2003) afirma que um atraso na colheita inibe a fixação de novos frutos pela maior competição por carboidratos, haja vista o consumo destes frutos maduros para a manutenção do metabolismo. Dessa forma, a colheita contínua, sistemática e periódica do Tahiti é importante para a manutenção de alta produtividade, já que esse cultivar apresenta normalmente, vários fluxos de florescimento durante o ano.

Este efeito inibitório do fruto foi atribuído tanto à difusão de substâncias supressivas florais (auxinas, giberelinas) das sementes e/ou frutos para dentro do ramo ou ainda por causar um estresse de carregamento (excesso na utilização de carboidratos) a qual reduz a formação de flores (Krajewski \& Rabe, 1995). Nenhuma explicação está completamente satisfatória, os frutos podem ser paternocárpicos como no caso da lima ácida 'Tahiti’ ou podem ter sido colhidos na época em que a indução ocorre.

No entanto, fatores históricos influenciam a formação de ramos frutíferos. Brotos originados na primavera de gemas auxiliares de ramos que produziram frutos foram vegetativos, enquanto aquelas oriundas de ramos apenas vegetativos foram usualmente florais (Krajewski \& Rabe, 1995). Em laranjeira 'Valencia' a presença de frutos sobre um galho reduziu o numero de brotos que emergiram, um efeito que se estendeu para os galhos adjacentes (Mullis et al., 1989). Sauer (1951) e Reuther (1973) também relataram efeitos semelhantes anteriormente. Se esses efeitos são menos sensíveis em variedades que não tem sementes ou em variedades que tiveram seus frutos colhidos ainda não foram relatados.

Apesar do florescimento primaveril dos citros ser vigoroso, o número de frutos cítricos colhidos não ultrapassa a 10\% das flores formadas, normalmente valores entre 
0,1\% e 3,5\% (Monselise, 1986). Segundo Castro et al. (2001), a queda fisiológica de flores e frutos jovens é uma disfunção decorrente, provavelmente, da competição dos frutos por carboidratos, água e outros metabólitos.

A maior competição ocorre quando os frutos possuem entre 0,5 a 2,0 cm (Davies \& Albrigo, 1994). Na realidade, até os frutos atingirem cerca de 4,0 cm de diâmetro, estão passíveis de caírem, caso não seja mantida uma taxa mínima de crescimento ou se o mecanismo de abscisão for estimulado artificialmente através do aumento do nível de etileno endógeno (Moss, 1976).

O primeiro período de abscisão em frutos ocorre nos estádios iniciais de desenvolvimento, estendendo-se desde a queda de pétalas até, aproximadamente, a $3^{\mathrm{a}} \mathrm{e}$ $4^{\text {a }}$ semanas após a antese, entretanto, existe um segundo período de abscisão, dependendo da variedade, com menor expressão, que ocorre entre novembro e dezembro no hemisfério sul (Davies \& Albrigo, 1994). Após esses dois períodos há uma drástica diminuição da abscisão até a maturação do fruto, excetuando-se sobre as condições ambientais adversas. González-Altozano \& Castel (2000a) verificaram que o estresse hídrico aumentou a queda de órgãos florais no florescimento, especialmente quando o potencial da água da folha estava próximo a -0,7 e -1,24 MPa ao amanhecer. Bertonha et al. (2004) verificaram que tanto o estresse hídrico quanto o excesso de umidade no solo aumentaram o número de frutos caídos em laranjeira 'Pêra', recomendando lâminas e freqüência diferenciadas de irrigação durante os diferentes estádios fenológicos. Períodos de alta temperatura ou ventos secos podem também ocasionar queda de frutos (Jones \& Cree, 1964).

Os hormônios vegetais controlam a fixação de frutos, provavelmente pela habilidade de mobilizar fotoassimilados e minerais (Monselise \& Goldschmidt, 1982). Aparentemente o ácido abscísico (ABA) e o etileno ativam a abscisão. O nível endógeno de ABA apresenta-se alto em ovários em desenvolvimento tanto no período de queda de pétalas (8-12 dias antes da antese), como no período de queda fisiológica, coincidindo com os dois picos de abscisão (Talón et al.,1997). Os níveis endógenos de ABA também 
aumentam durante períodos de estresse. Entretanto, a aplicação externa de ABA não causa abscisão (Goren, 1993).

O pegamento do fruto é favorecido pelo tipo de brotação na qual é formado. Segundo Davenport (1990) a brotação em citros distribui-se em brotos com folhas (brotações vegetativas), com flores e folhas (brotações mistas) e apenas com flores (generativos). Brotações mistas favorecem o pegamento ao passo que o aborto de órgãos reprodutivos é quase total em brotações generativas durante os dois primeiros meses após a antese, exceção para limão e 'Pomelo' (Erner \& Shomer, 1996). Além disso, a formação de flores é acompanhada pela redução do comprimento da brotação (SpiegalRoy \& Goldschmidt, 1996). As brotações generativas são as mais curtas e apresentam níveis baixos de giberelina endógenas (Goldschmidt \& Monselise, 1970).

Em geral, as brotações mistas fixam as flores entre 4 e 6 vezes a mais que as inflorescências generativas, segundo revisão feita por Spiegal-Roy \& Goldschmidt (1996), ainda que em todas as brotações tenha ocorrido queda de frutos. Ruiz et al. 2001 verificaram que em laranjeiras 'Washington Navel' mais de 87\% das inflorescências com mais de uma flor e sem folhas caíram até o trigésimo dias após a antese. Nos 13\% finais, o número de frutos caiu de 4 para 1,8 frutos por inflorescência. Em contraste, a maioria das inflorescências com múltiplas flores e folhas tiveram pelo menos um fruto até o trigésimo dia.

O preferencial pegamento em ramos mistos pode ser explicado principalmente em termos de suprir fotossintetizados ao desenvolvimento do fruto pelas folhas adjacentes ao fruto (Moss, 1970, Moss et al., 1972).

Jahn (1973) comenta que existe um gradiente floral, com uma maior tendência de produção de brotações mistas na direção da base dos ramos. Valiente \& Albrigo (2004) trabalhando com laranjeiras 'Valência' e 'Hamilin', na Flórida, encontraram que as gemas em posições apicais do ramo desenvolveram mais flores que as localizadas na base. Flores basais apenas se desenvolveram em níveis elevados de indução floral. Além 
disso, estes autores verificaram que as brotações foram superiores em ramos formados no surto do verão (mais novos) comparativamente aos ramos formados no surto primaveril.

No entanto, após o período de indução, baixas temperaturas por ocasião da brotação aumentam a proporção de brotações generativas (Moss, 1969) ao passo que altas temperaturas aumentam a possibilidade de brotações vegetativas (Valiente \& Albrigo, 2004). Podas localizadas também aumentam a proporção de brotações generativas (Cook, 1992 citado por Krajewski \& Rabe, 1995). Observa-se ainda que há uma correlação positiva entre densidade de brotação e brotações generativas, concluindo que a habilidade para manipular a presença ou ausência de folhas será de grande valor para os citricultores, uma vez que um maior número de flores são fixadas com um aumento no número de folhas. (Krajewski \& Rabe, 1995).

\subsection{Manejo de irrigação em citros}

A maioria dos trabalhos publicados referentes a manejo de irrigação visa aumentar a eficiência na aplicação de água, com perdas mínimas na produtividade pela diminuição na quantidade de água aplicada durante certos estádios de desenvolvimento das plantas e/ou épocas do ano quando a produtividade e qualidade apresentam baixa sensibilidade ao estresse hídrico.

Segundo Hilgeman (1977) o estresse hídrico em plantas cítricas afeta o peso dos frutos. Também pode reduzir a produção por ocasionar queda de frutos. Evidenciando assim, a importância da irrigação em todo o ciclo para diminuir os riscos. Para Doorenbos \& Kassam (1994) o período de florescimento e pegamento dos frutos são, geralmente, consideradas a fases mais críticas ao estresse hídrico.

Ginestar \& Castel (1996) estudando a resposta de plantas jovens de tangerinas 'Clementina' irrigadas por gotejamento, durante diferentes períodos fenológicos, 
encontraram que o estresse hídrico severo foi prejudicial em todas as fases da cultura, porém a maior queda na produtividade ocorreu no período de florescimento e pegamento dos frutos. González-Altozano \& Castel (2000b) alertam que as estratégias visando à redução do volume aplicado de água, na Espanha, não devem ser conduzidas durante a primavera pois os ramos formados serão fundamentais para o pegamento e persistência dos frutos.

Nas condições climáticas paulistas, a irrigação tem um caráter complementar, o que torna indispensável o manejo das irrigações (Pires, 1992). Entretanto, são poucos os trabalhos produzidos no Brasil a respeito do tema comparativamente à Espanha e Estado Unidos.

Os critérios para o manejo de irrigação podem envolver metodologias baseadas nas condições de umidade do solo, clima e planta, ou conjugadas.

Segundo Souza \& Matsura (2002) diversos são os métodos para a determinação da umidade do solo, como, o gravimétrico, considerado o método direto padrão, além dos métodos indiretos, que estimam, a partir de outras propriedades do solo, tais como a termalização de neutros, resistência elétrica e reflectometria no domínio do tempo (TDR). Outro equipamento muito utilizado dado a sua simplicidade, confiabilidade e baixo custo são os tensiômetros.

Smajstrla et al. (1985) utilizaram tensiômetros para manejar a irrigação em laranjeiras 'Valência' e verificaram que o crescimento das plantas no primeiro ano foi excelente a $20 \mathrm{kPa}$ de tensão da água no solo comparadas com 10 e $40 \mathrm{kPa}$, enfatizando que é importante à manutenção adequada mas não excessiva de umidade na zona radicular.

Paramasivam et al. (2000) cita que, na Flórida, para otimização da irrigação tem sido comumente recomendando valores de tensão de 10 e $15 \mathrm{kPa}$ durante os meses de Janeiro a Maio (período seco) e Junho a Dezembro (período chuvoso), respectivamente. No entanto, os autores ressaltam que nestas tensões podem ocorrer casos de percolação e 
lixiviação no período chuvoso. Gerard \& Sleeth (1960) citados por Shalhevet \& Levy (1990) recomendam valores de 50 a $70 \mathrm{kPa}$ a 0,6 m de profundidade para indicar o momento de irrigar.

Na Espanha, González-Altozano \& Castel (2000b) verificaram que tensões no solo de $45 \mathrm{kPa}$, no perfil de 0,4 m de profundidade, praticamente cessaram o alongamento dos ramos de tangerina 'Clementina' na fase de florescimento e pegamento dos frutos.

Medina \& Machado (1998) verificaram que não houve decréscimo na taxa de assimilação de $\mathrm{CO}_{2}$, transpiração, eficiência no uso da água, potencial de água na folha e conteúdo relativo de água em laranjeira 'Valencia' quando a tensão no substrato foi menor a $40 \mathrm{kPa}$.

Uma outra técnica muito utilizada é o manejo da irrigação baseada na reposição da água evapotranspirada pela cultura.

Na Flórida, Smajstrla \& Koo (1984) estudando o efeito do manejo de irrigação baseado na reposição da água evaporada em 100, 50 e 25\% do Tanque classe A em laranjeira 'Valência' durante cinco anos, verificaram que a produtividade não foi afetada pela quantidade de água aplicada, indicando que todos os tratamentos foram eficientes na prevenção do estresse hídrico.

Castel \& Buj (1990), na Espanha, avaliando a resposta de laranjeiras 'Salustiana' as irrigações baseadas na reposição de $60 \%$ da evaporação do Tanque Classe A ao longo do ano (controle), reposição baseada em 80 e 60\% do controle, 60\% do controle no florescimento e pegamento e $60 \%$ do controle durante o período de maturação dos frutos encontraram que os tratamentos baseados na reposição anual de 80 e $60 \%$ do controle reduziram significativamente a produção em $5 \%$ e 15\%, respectivamente. O tratamento baseado em $60 \%$ do controle somente no florescimento reduziu em $4 \%$ a produtividade, o conteúdo de ácido e suco. 
Torrecillas et al. (1993) trabalhando com plantas de limão na Espanha, submetidas a irrigações baseadas em 100\% da evapotranspiração da cultura (ETc) ao longo do ano e irrigadas a $25 \%$ da ETc, excetuando-se durante o período de rápido desenvolvimento dos frutos (após o "june drop”) quando foi aplicado 100\% da ETc, verificaram que o déficit hídrico não afetou a dinâmica de crescimento dos frutos e produtividade, indicando que um déficit controlado pode economizar água e melhorar a eficiência de uso da água. Este resultado foi ratificado por Domingo et al. (1996), durante quatro anos de experimento no mesmo local.

Castel (1994) estudando a resposta de plantas jovens de tangerina 'Clementina' irrigada por gotejamento a 50, 80, 110 e 140 \% da evapotranspiração da cultura (ETc) determinada via lisímetro de pesagem, verificou que a irrigação a 50 \% produziu alto estresse hídrico, reduziu o crescimento da planta e diminuiu o número de frutos por planta. O crescimento ótimo foi obtido com irrigação de $110 \%$ da ETc.

Posteriormente, para estudar mais detalhadamente o efeito do déficit regulado da irrigação no período de rápido crescimento do fruto (meses de julho a agosto), González-Altozano \& Castel (2000a) verificaram que o déficit possibilitou reduzir o consumo de água em torno de 6 a 22\% sem afetar a produtividade e qualidade dos frutos, desde que o valor limite de potencial da água na folha ao amanhecer não ultrapasse a $-1,2 \mathrm{MPa}$.

No Brasil, Bertonha et al. (2004) avaliando níveis de irrigação (10, 15, 20 e 25 mm) complementar em laranjeira 'Pêra', irrigadas por gotejamento em condições de campo, encontraram que a produção, produtividade, peso médio dos frutos e a quantidade de sólido solúvel produzido por árvore apresentaram uma relação quadrática em função das lâminas aplicadas.

O manejo de irrigação pode ainda ser conduzido via balanço hídrico do solo, ou seja, as diferenças entre as entradas (chuvas e irrigação) e saídas (escoamento 
superficial, drenagem e evapotranspiração) irrigando a partir do estabelecimento de limites críticos de esgotamento da água disponível na zona do sistema radicular.

Marler \& Davies (1990) compararam o crescimento de laranjeiras 'Hamlin', com 1 ano de idade, mantidas a 20, 45 e 65\% de esgotamento da água no solo e concluíram que houve um decréscimo no crescimento radicular e dos ramos nas plantas mantidas a 65\%, enquanto os tratamentos com 20 e $45 \%$ não ocorreram diferenças quanto ao crescimento vegetativo. Posteriormente, sob a mesma variedade, Davies \& Zalman (2000) não encontraram diferenças no crescimento vegetativo quando as plantas foram mantidas entre 30 e 50\% de esgotamento da água do solo.

Nas condições do Estado de São Paulo no período de inverno há uma diminuição na disponibilidade energética via radiação solar e na atividade fotossintética e a transpiração nos citros (Machado et al., 2002) sendo provável trabalhar com um nível de esgotamento da água no solo maior neste período, economizando irrigações e evitando a perda de nutrientes via lixiviação. A queda na disponibilidade energética e a porcentagem de esgotamento permissível da água no solo sem perda na evapotranspiração potencial foi desenvolvida por Denmead \& Shaw (1962) em plantas de milho, na qual verificaram que em condições de evapotranspiração potencial elevada o declínio da evapotranspiração real ocorreu quando a tensão média do solo estava em torno de $30 \mathrm{kPa}$. Quando a evapotranspiração potencial estava baixa, a real não caiu até perto de $1200 \mathrm{kPa}$.

Segundo Jones (2004) tal questionamento tem levado a sugestão de que o manejo de irrigação pode ser obtido de forma mais precisa pelo uso das respostas da planta, como o potencial de água na folha no momento de máxima hidratação (ao amanhecer). Diversos trabalhos (Shalhevet \& Levy, 1990; González-Altozano \& Castel, 2000a e González-Altozano \& Castel, 2000b) tem relatado valores máximos de potencial de água na folha sem detrimento do crescimento vegetativo e/ou reprodutivo para as variedades cítricas. A maioria situa-se na faixa de -0,3 a -1,2 MPa. 


\subsection{Evapotranspiração das plantas cítricas}

Segundo Pires (1992) as plantas cítricas transpiram durante o ano todo e, em geral, sua necessidade de água varia entre 900 e $1200 \mathrm{~mm} \mathrm{ano}^{-1}$, de acordo com os seguintes fatores: clima, espécie vegetal, combinação copa-porta-enxerto, idade da planta, limpeza do terreno e disponibilidade de água do solo.

Na Espanha Castel \& Buj (1990) relataram que a evapotranspiração anual de laranjeiras 'Salustiana' irrigadas por gotejamento foi de $840 \mathrm{~mm} \mathrm{ano}^{-1}$. Em outras regiões, Shirgure et al. (2000) citam que limoeiros de 4 anos de idade, no Tajaquistão Central, requereram $740 \mathrm{~mm}$ anualmente. Na Flórida, Reitz (1968) citado por Shirgure et al. (2000) estima em 1016 a $1143 \mathrm{~mm}$ ano $^{-1}$. No Brasil, Cintra et al. (2000) encontram que a evapotranspiração anual de laranjeira 'Pera' sob cinco porta-enxertos de citros no tabuleiro costeiro foi de 757 a $945 \mathrm{~mm}$. Cruz (2003) verificou que o consumo de laranjeira 'Valencia' foi de $1271 \mathrm{~mm}$ sob um latossolo vermelho amarelo.

Estas estimativas foram obtidas pelo o método do balanço hídrico do solo, descrito por Reichardt (1990). No entanto, diversos autores reportam o uso de lisímetros de pesagem como ferramenta padrão em estudos de consumo de água das culturas, como também na calibração de modelos agrometeorológicos de estimativa (Campeche, 2002; Silva et al., 1999 e Howell et al., 1991).

Os primeiros trabalhos com lisimetria em citros foram feitos por Green \& Bruwer (1979), na África do Sul, na qual construíram com sucesso três lisímetros de pesagem, com uma área de 13,4 $\mathrm{m}^{2}$ e profundidade de 1,8 $\mathrm{m}$ com uma massa de aproximadamente 50 t e uma precisão de 4 kg.

Boman (1994) construiu uma bateria de 21 lisímetros de drenagem de 3,5 m de diâmetro e $1 \mathrm{~m}$ de profundidade para determinação da evapotranspiração de plantas jovens de laranjeira 'Valência' sobre porta-enxerto de citromelo 'Swingle', na Flórida, verificando uma evapotranspiração média anual de 13,8 L por planta. 
Castel (1997) na Espanha encontrou que a evapotranspiração anual de plantas jovens de ‘Clementina' irrigadas por gotejamento foi de 290 e 397 mm em 1990 e 1991, que correspondeu aos valores de Coeficiente de Cultivo (Kc) de 0,25 e 0,31, respectivamente. Verificaram ainda que a evaporação do solo durante 1991 variou de 50\% a 30\% da Evapotranspiração de Referência (ETo).

Yang et al. (2003) estudando a evapotranspiração de plantas de 'Murcote' com 8 anos de idade com lisimetria de pesagem encontraram que a evapotranspiração apresentou um comportamento sazonal, com uma taxa de 4,4 $\mathrm{mm} \mathrm{dia}^{-1}$ no verão e 0,6 mm dia ${ }^{-1}$ no inverno. O Kc médio obtido foi de 0,91 a 0,75 durante o verão e inverno respectivamente. A evaporação do solo foi de 33\% da ETo durante o período de inverno e $11 \%$ no verão e ainda, a máxima absorção de água pelas plantas ocorreu na camada de 0,3 a 0,6m de profundidade no inverno e de 0 a $1,2 \mathrm{~m}$ no período do verão. Este comportamento sazonal também foi observado por Fares \& Alva (1999). 


\section{VARIAÇÃO SAZONAL NA EVAPOTRANSPIRAÇÃO DE PLANTAS JOVENS DE LIMEIRA ÁCIDA ‘TAHITI’}

\section{Resumo}

O objetivo deste trabalho foi estudar a variação sazonal diária e horária na evapotranspiração de plantas jovens de lima ácida 'Tahiti’ sob condições de campo, definindo valores de coeficiente de cultivo. O estudo foi conduzido em Piracicaba, durante o inverno de 2003 e verão de 2004. Utilizou-se um lisímetro de pesagem eletrônica de 2,7 m de diâmetro e 0,8 m de profundidade com uma planta de dois anos de idade, localizado no centro da área experimental com 322 plantas. Todas as plantas do pomar foram irrigadas por quatro gotejadores autocompensantes, inclusive a do lisímetro. Os resultados permitiram verificar que no período de verão a média da evapotranspiração da cultura $(E T c)$ foi de $1,50 \mathrm{~mm} \mathrm{dia}^{-1}$ decrescendo a 0,66 $\mathrm{mm} \mathrm{dia}^{-1}$ nos meses de inverno. O coeficiente de cultivo $(K c)$ médio obtido foi de 0,36 e 0,22 durante o período de verão e inverno, respectivamente. A ETc máxima para o período de inverno ocorreu às 14:00 h enquanto que no verão foi às 12:00 h. Além disso, ocorreram perdas por evaporação diária noturna de 17,4 \% e 13,4\% da ETc para o período de inverno e verão respectivamente. A curva de evaporação do solo $(K e)$ foi semelhante em ambos os períodos estudados.

\section{Summary}

The objective of this study was to investigate seasonal variations in daily and hourly evapotranspiration $(E T c)$ of acid lime 'Tahiti' trees under field conditions, defining values of crop coefficients. The study was carried out in Piracicaba, Brazil 
during the winter of 2003 and the summer of 2004. A weighing lysimeter of $2.7 \mathrm{~m}$ diameter and $0.8 \mathrm{~m}$ depth planted with a two-year-old tree that was localized at the center of experimental area of 322 trees. The lysimeter tree was irrigated, like others in the plot, by four pressure compensated emitters. Average ETc was $1.50 \mathrm{~mm} \mathrm{dia}^{-1}$ in summer period and dropped to $0.66 \mathrm{~mm} \mathrm{dia}^{-1}$ in winter months. The average seasonal crop coefficient $(K c)$ was 0.36 and 0.22 for summer and winter, respectively. The time of maximum ETc was $1200 \mathrm{~h}$ in summer and $1400 \mathrm{~h}$ in winter. Moreover, night soil evaporation occurred representing $17.4 \%$ and $13.4 \%$ of daily ETc for winter and summer. The curve of soil evaporation $(\mathrm{Ke})$ in both seasons showed similar results.

\subsection{Introdução}

O Estado de São Paulo se destaca como uma das principais regiões produtoras de citros do mundo. Apesar de apresentar uma precipitação pluviométrica anual suficiente é comum à ocorrência de períodos com déficit hídrico propiciando quebras de produção. Em função disso, a opção pela técnica de irrigação é uma medida economicamente viável desde que feita de maneira criteriosa.

O conhecimento da evapotranspiração $(E T c)$ e do coeficiente de cultivo $(K c)$ é fundamental para se outorgar, dimensionar e manejar a irrigação de uma cultura. Uma vez que estes valores variam conforme a disponibilidade energética do local, variedade e idade da planta é importante à obtenção de valores regionalizados.

Nas condições climáticas do Estado de São Paulo, Machado et al. (2002) verificou queda na atividade fotossintética e transpiração nos citros no período de inverno. Sendo assim, é provável que se possa trabalhar com valores de $K c$ menores neste período, economizando água e evitando a perda de nutrientes via lixiviação.

Diferentes técnicas têm sido testadas para se determinar a evapotranspiração da cultura, como o método do balanço hídrico do solo proposto por Jensen (1973) e descrito por Reichardt (1990). De maneira mais simplificada, Jackson et al. (1977) propuseram a medida da evapotranspiração baseada na diferença de temperatura da planta. No entanto, 
diversos autores reportam o uso de lisímetros de pesagem como ferramenta padrão em estudos de perda de água das culturas, seja na determinação da evapotranspiração, como também na calibração de modelos agrometeorológicos de estimativa (Campeche, 2002; Silva et al., 1999 e Howell et al., 1991)

Entretanto, a grande maioria das informações quanto ao consumo hídrico das plantas cítricas, via lisimetria, provêem da literatura internacional (Green \& Bruwer, 1979; Boman,1994; Ginestar \& Castel, 1996; Castel, 1997; González-altozano \& Castel, 2000a e Yang et al., 2003).

Diante do exposto, os objetivos deste estudo foram analisar a variação sazonal da evapotranspiração diária e horária de plantas jovens de limeira ácida 'Tahiti' em Piracicaba, durante o inverno e verão, definindo valores de coeficiente de cultivo $(K c)$.

\subsection{Material e Métodos}

O experimento foi realizado na Fazenda Areão da Escola Superior de Agricultura

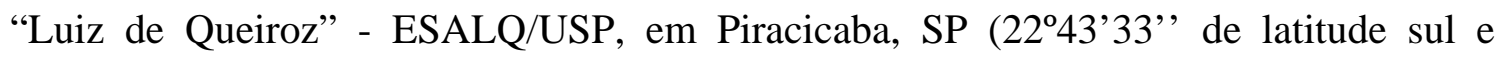
47038'0' de longitude oeste com uma altitude de $511 \mathrm{~m}$ ). O experimento foi conduzido durante o inverno/2003 (84 dias, de 10/06/2003 a 22/09/2003) e verão/2004 (49 dias, de 22/12/2003 a 20/03/2004). A temperatura, a umidade relativa média e o total de precipitação durante a condução do experimento foram de $18,9^{\circ} \mathrm{C}, 62,9 \%$ e $43,5 \mathrm{~mm}$ no inverno e $23,8^{\circ} \mathrm{C}, 72,5 \%$ e $615,5 \mathrm{~mm}$ no verão. O solo da área experimental é classificado como Nitossolo vermelho segundo a classificação brasileira de solos (Embrapa, 1999). A capacidade de água disponível no solo foi de $125 \mathrm{~mm} \mathrm{~m}^{-1}$ para uma densidade média de $1300 \mathrm{~kg} \mathrm{~m}^{-3}$. Estes valores foram determinados por abertura de trincheiras em três pontos da área, com coleta de anéis volumétricos com amostras indeformadas a cada $0,2 \mathrm{~m}$ até $1,0 \mathrm{~m}$ de profundidade.

As limeiras ácidas 'Tahiti' (Citrus latifolia Tanaka) enxertadas sobre plantas de citrumeleiro 'Swingle' [Poncirus trifoliata (L.) Raf. x C. paradisi Macf.] foram plantadas em espaçamento $7 \times 4 \mathrm{~m}$, obtendo-se um total de 322 plantas em uma área 
experimental de aproximadamente 1 ha (Figura 1A). Foram plantadas em sulcos na primeira quinzena de maio de 2001, sendo a calagem e adubação realizadas de acordo com Raij et al. (1992). Os tratos culturais consistiram de pulverizações com inseticidas, roçagem e controle químico das plantas daninhas nas entrelinhas. O sistema de irrigação utilizado no pomar foi por gotejamento, com quatro emissores autocompensantes por planta, com vazão de $4 \mathrm{~L} \mathrm{~h}^{-1}$ cada, em turno de rega de 2 a 4 dias para reposição da água evapotranspirada.
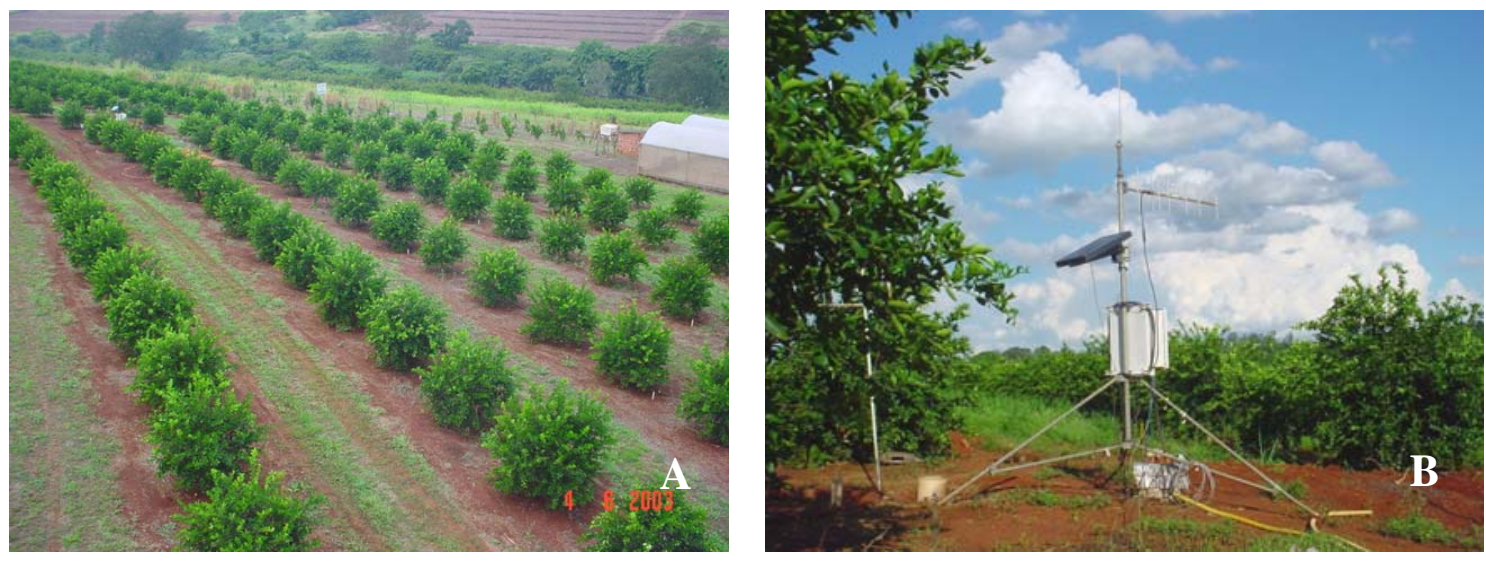

Figura 1 - Área experimental (A) e sistema automático de coleta de dados (B)

Para determinação da evapotranspiração da cultura (ETc) foi utilizado um lisímetro de pesagem com células de carga eletrônica acopladas a um sistema automático de coleta de dados (modelo CR23X da Campbell Scientific ${ }^{1}$, Logan, Utah, EUA) (Figura 1B). O lisímetro localizava-se no centro da área experimental, contendo uma planta com as mesmas características e sob o mesmo sistema de manejo das plantas externas. Apresentava as dimensões de 2,7 $\mathrm{m}$ de diâmetro e 0,8 $\mathrm{m}$ de profundidade com 0,25 kg de exatidão (Figura 2A). Maiores detalhes sobre construção e calibração deste equipamento podem ser obtidos em Campeche (2002). A massa do lisímetro foi continuadamente medida a cada segundo e valores médios foram registrados a cada hora.

\footnotetext{
${ }^{1}$ Referências à marca registrada não constituem endosso por parte do autor.
} 
A evapotranspiração da cultura (ETc) horária, em milímetros de água, foi obtida pela diferença entre as leituras horárias dividida pela área útil de cada planta $\left(28 \mathrm{~m}^{2}\right)$, descontadas as chuvas, irrigações e as drenagens ocorridas no período, de acordo com a Equação (1)

$E T c=\frac{M_{i}-M_{i-1}-D+P . A+I}{A}$

em que:

$E T c$ - Evapotranspiração da cultura, mm período $^{-1}$

$M i$ - Massa do lisímetro, $\mathrm{kg}$

Mi-1 - Massa do lisímetro no tempo anterior, $\mathrm{kg}$

$A$ - Área do lisímetro, $\mathrm{m}^{2}$

$D$ - Drenagem, kg

$P$ - Precipitação, mm

$I$ - Irrigação, kg
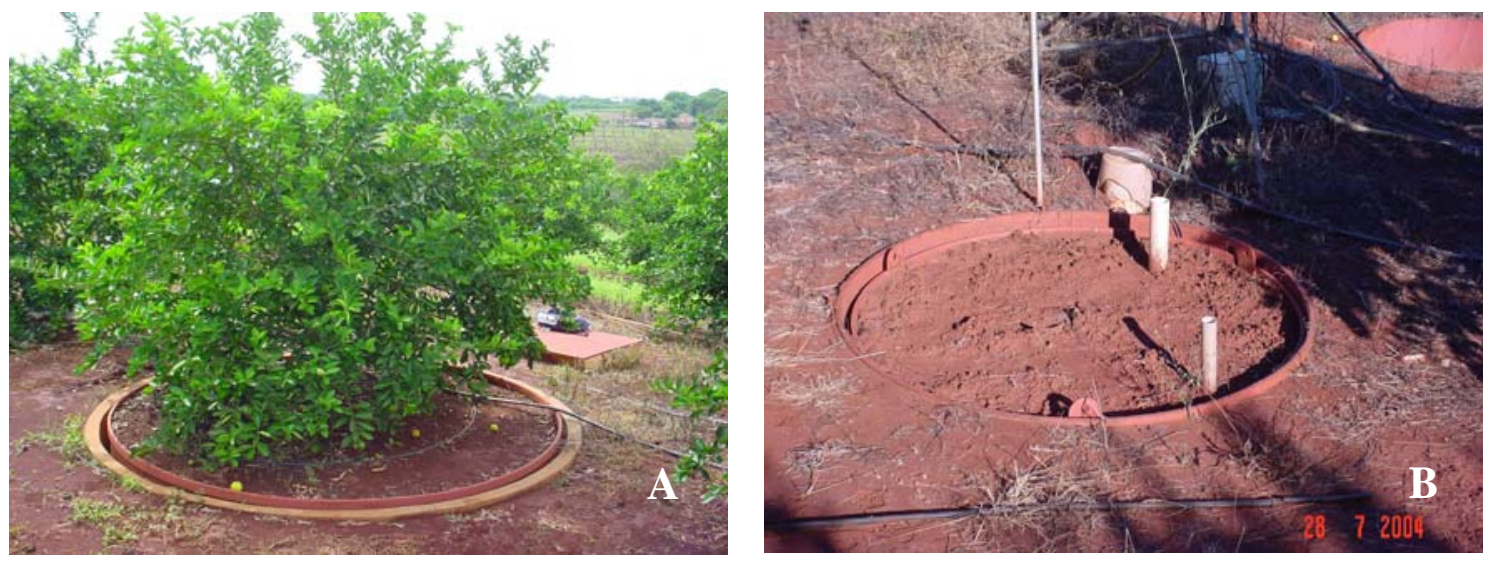

Figura 2 - Lisímetro utilizado para a determinação da evapotranspiração da cultura $(E T c)(B)$ e para a determinação da evaporação do solo $(E v)(B)$ 
Para a ETc diária foi considerado apenas o valor instantâneo, registrado a meianoite de cada dia, quando o elemento meteorológico vento era nulo ou fraco $\left(<1,5 \mathrm{~m} \mathrm{~s}^{-1}\right)$. Além disso, valores inconsistentes foram detectados e descartados especialmente em dias com chuva, sugerindo que a quantidade de chuva efetivamente coletada pelo lisímetro foi diferente da registrada pelo pluviômetro, distante $70 \mathrm{~m}$ do lisímetro. Problema similar na determinação da ETc ocorreu com Castel (1997) e Green et al. (1984).

Um segundo lisímetro de pesagem foi utilizado para a determinação da evaporação do solo diária $(E v)$. Sua dimensão era de 1,6 $\mathrm{m}$ de diâmetro e $0,7 \mathrm{~m}$ de profundidade, com exatidão de 0,156 kg (Figura 2B). Com esse lisímetro foi possível obter um coeficiente de evaporação do solo (Equação 2) em função do número de dias após a chuva e ou irrigação, representada pela relação entre a $E v(\mathrm{~mm})$ e a $E T o(\mathrm{~mm})$ calculado a partir do maior intervalo de chuvas sucessivas ocorrido em cada período (50,4 mm no verão e 16,3 mm no inverno). Tal coeficiente possibilita a correção do coeficiente de cultivo (Kc, Allen et al., 1998) para cultivo sob irrigação tradicional (aspersão) sob qualquer freqüência de molhamento. A evaporação diária foi obtida pela diferença de peso obtida a meia-noite, descontado as chuvas e as drenagens ocorridas no período.

$K e=\frac{E v}{E T o}$

em que:

$K e$ - Coeficiente de evaporação do solo

$E v$ - Evaporação do solo, $\mathrm{mm} \mathrm{dia}^{-1}$

ETo - Evapotranspiração de referencia, $\mathrm{mm} \mathrm{dia}^{-1}$

A estimativa da Evapotranspiração de Referência (ETo) foi calculada segundo o método de Penman-Monteith parametrizado por Allen et al. (1998) com base nos dados 
climáticos armazenados por uma estação agrometeorológica automática, distante $70 \mathrm{~m}$ dos lisímetros.

Para certificar de que o crescimento da planta do lisímetro era similar as demais plantas do pomar, foi realizada uma avaliação fitométrica no final do período de inverno (12/09/2003), consistindo de medidas da altura, perímetro do caule (0,05 m acima do ponto de enxertia) e diâmetro da copa da planta do lisímetro e em 10 plantas externas (Tabela 1) O volume da copa foi calculado usando o procedimento descrito por Hutchinson (1977).

Tabela 1. Medidas fitométricas da planta cultivada no lisímetro e de plantas cultivadas na área

\begin{tabular}{lcccc}
\hline Planta & Altura & $\begin{array}{c}\text { Diâmetro da } \\
\text { copa } \\
(\mathbf{m})\end{array}$ & $\begin{array}{c}\text { Perímetro do } \\
\text { caule }\end{array}$ & $\begin{array}{c}\text { Volume da } \\
\text { copa } \\
\left(\mathbf{m}^{3}\right)\end{array}$ \\
\hline Lisímetro & 2,40 & 3,0 & 0,23 & 5,4 \\
\hline Pomar $^{1}$ & 2,74 & 3,0 & 0,29 & 6,2 \\
\hline Valores médios de 10 plantas. & & &
\end{tabular}

\subsection{Resultados e Discussão}

A evolução da $E T c$ nos dois períodos está presente na Figura 3. Observa-se que houve uma variação maior no período do verão comparativamente ao inverno, provavelmente devido a ciclos de evaporação do solo dentro do lisímetro, provocados pela chuva, ainda que a planta recobrisse a área total do lisímetro (Figura 2A). Houve um padrão sazonal da evapotranspiração. A média de $E T c$ variou entre $1,5 \mathrm{~mm} \mathrm{dia}^{-1}$ no verão e $0,66 \mathrm{~mm}$ dia ${ }^{-1}$ no inverno. O máximo valor de $E T c$ foi de $2,12 \mathrm{~mm} \mathrm{dia}^{-1}$ (16/01/2004) e o mínimo foi de 0,21 $\mathrm{mm} \mathrm{dia}^{-1}$ (25/08/2003). Esta sazonalidade também foi observada por Yang et al. (2003) com valores de 4,4 $\mathrm{mm} \mathrm{dia}^{-1}$ no verão e 0,6 mm dia $^{-1}$ no inverno para plantas de laranja 'Murcote' sob condições de estufa porém relacionadas com a área do lisímetro $\left(1,767 \mathrm{~m}^{2}\right)$. Em estudo semelhante, Castel (1997) 
utilizando um lisímetro de pesagem com plantas de laranja 'Clementina' encontraram que a evapotranspiração relacionada ao espaçamento de plantio $\left(23,1 \mathrm{~m}^{2}\right)$ variou de 0,7 $\mathrm{mm} \mathrm{dia}^{-1}$ no inverno a 1,8 e 2,0 $\mathrm{mm} \mathrm{dia}^{-1}$ no verão. Considerando que em limeiras ácidas cultivadas em clima tropical não há uma predominância de um estádio fenológico ao longo do ano, podemos deduzir que, em média, mais de $50 \%$ do volume de água aplicado pela irrigação no inverno pode ser reduzido quando comparado ao período do verão.

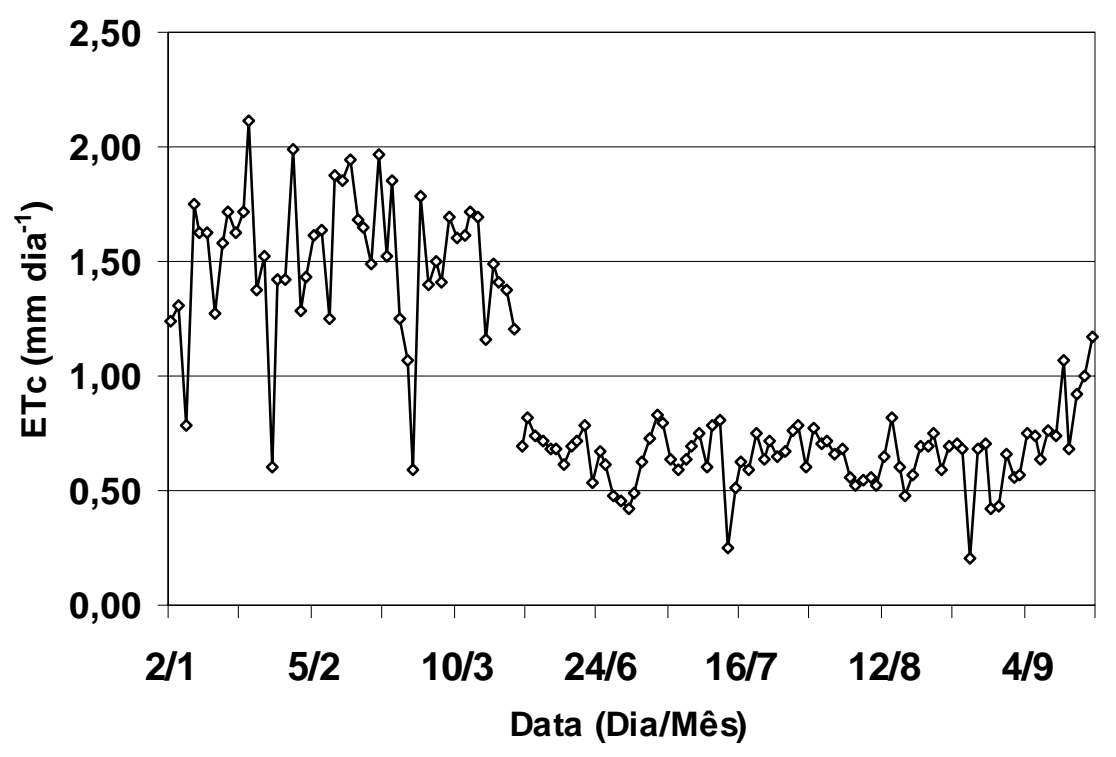

Figura 3 - Evapotranspiração diária de limeira ácida ‘Tahiti’ durante o período de verão e inverno

O coeficiente de cultura $(K c)$ obtido pela regressão linear entre a ETc e ETo foi de 0,36 para o período de verão e 0,22 para o período de inverno (Figura 4A e 4B). Castel (1997) encontraram valores de 0,2 a 0,7. Boman (1994) relatou que os valores de $K c$ obtidos via lisimetria na Flórida, em plantas com 3-4 anos de idade ajustados para uma área de $28 \mathrm{~m}^{2}$, foram de 0,19 durante o inverno e de 0,34 no verão. Allen et al. (1998) no Boletim da FAO-56 recomenda valores de 0,40 a 0,50 para diferentes estádios 
fenológicos sob mesmas condições obtidas neste trabalho e sob uma evaporação mínima na área total da planta (espaçamento da cultura). Quanto à dispersão encontrada em ambos os períodos analisados, Allen et al. (1998) explica que, em experimentos com lisímetros, pontos dispersos podem ser considerados normais e, são causados pela variação no clima, direção do vento e erros na determinação da radiação líquida e ETo. Yang et al. (2003) comenta que estas variações também são provocadas pela demanda atmosférica, sendo esta maior no verão.
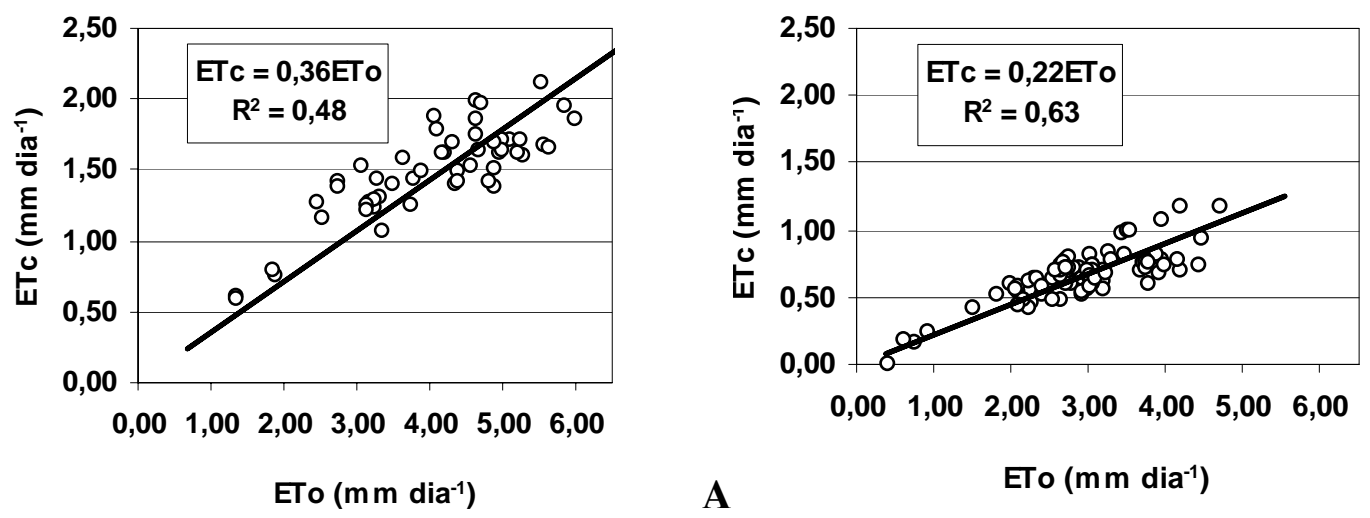

Figura 4 - Regressão linear entre a evapotranspiração da cultura $(E T c)$ e a evapotranspiração de referência (ETo) para o período de verão (A) e inverno (B)

A Figura 5 apresenta a variação média horária da ETc com base em três dias escolhidos em cada período sob condições de mínima evaporação do solo. No verão, a ETc iniciou às 06:00 h (horário local) com os valores aumentando até as 09:00 h porém diminuindo às 10:00 h, voltando a aumentar com o pico máximo às 12:00 h. Ocorreu um decréscimo acentuado a partir das 13:00 com uma leve diminuição às 17:00 h, sendo nula somente às 23:00 h. Em contraste, no inverno a ETc iniciou somente às 08:00 h aumentando suavemente até o pico às 14:00 h decrescendo após. Interessante notar que ocorreram perdas por evaporação do solo mesmo durante a noite em ambos os períodos, provavelmente, devido ao gradiente térmico do solo, provocado pela diferenças de temperatura no perfil. Apesar da pequena evapotranspiração ocorrida durante o período noturno, esses valores não devem ser negligenciados no somatório da evapotranspiração 
diária quando se utilizam modelos de estimativas de perda de água e principalmente técnicas de determinação da evapotranspiração. A evaporação noturna (contabilizada a partir do início do saldo-radiômetro apresentava valores negativos) correspondeu a uma média de 17,4 \% e 13,4\% para o período de inverno e verão respectivamente. Pereira (1998) trabalhando com lisímetro de pesagem para determinação da evapotranspiração de referência, constatou que, em média, 15\% da evapotranspiração diária é ocorrida durante o período noturno.

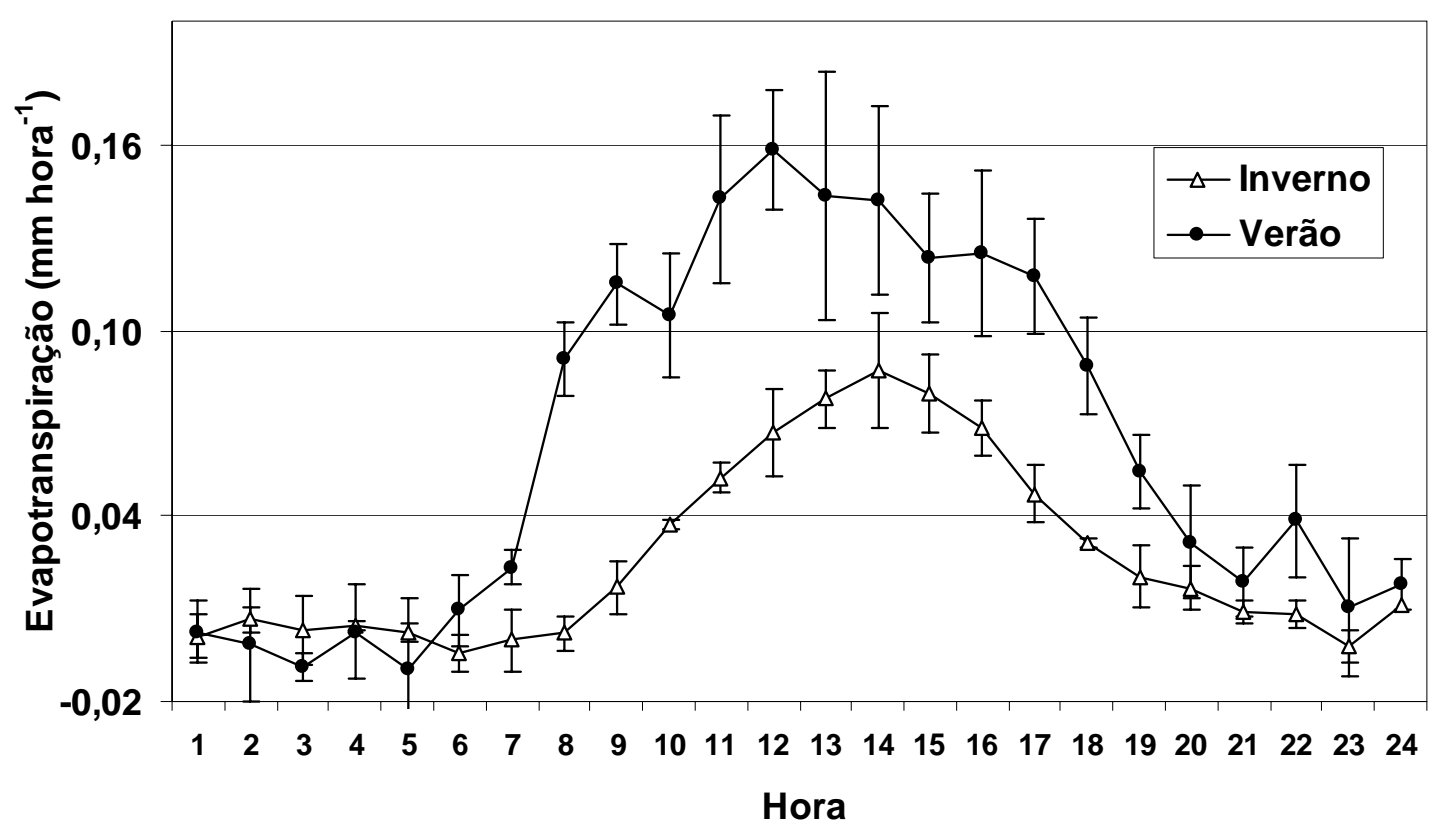

Figura 5 - Evapotranspiração da cultura horária para os períodos de verão e inverno. Pontos representam o valor médio de 3 repetições e as barras verticais o desvio-padrão

Os valores obtidos de $K c$ neste trabalho somente serão válidos para serem utilizados em irrigação localizada, uma vez que na determinação da ETc não foi considerada a evaporação do solo para a área correspondente a diferença entre a área útil da planta e área do lisímetro ( $28 \mathrm{~m}^{2}$ e 5,72 $\mathrm{m}^{2}$, respectivamente). Para a utilização em irrigação em área total (aspersão) faz necessária a correção dos valores de ETc, acrescentando evaporação do solo correspondente à diferença de área entre o 
espaçamento da cultura e do lisímetro. Com a evaporação do solo depende da freqüência do molhamento do solo a quantificação da evaporação pode ser feita através da curva de evaporação do solo $(\mathrm{Ke})$ em função do número de dias após a chuva e/ou irrigação e ETo para o período de verão e inverno (Figura 6). Pode-se observar que o comportamento foi semelhante em ambos os períodos estudados, com os ajustes obtidos de $K e=1,26 \mathrm{~d}^{-0,63} \mathrm{e}$ $\mathrm{R}^{2}=0,95$ para o inverno e verão com $K e=1,2 \mathrm{~d}^{-0,62}$ e $\mathrm{R}^{2}=0,82$.

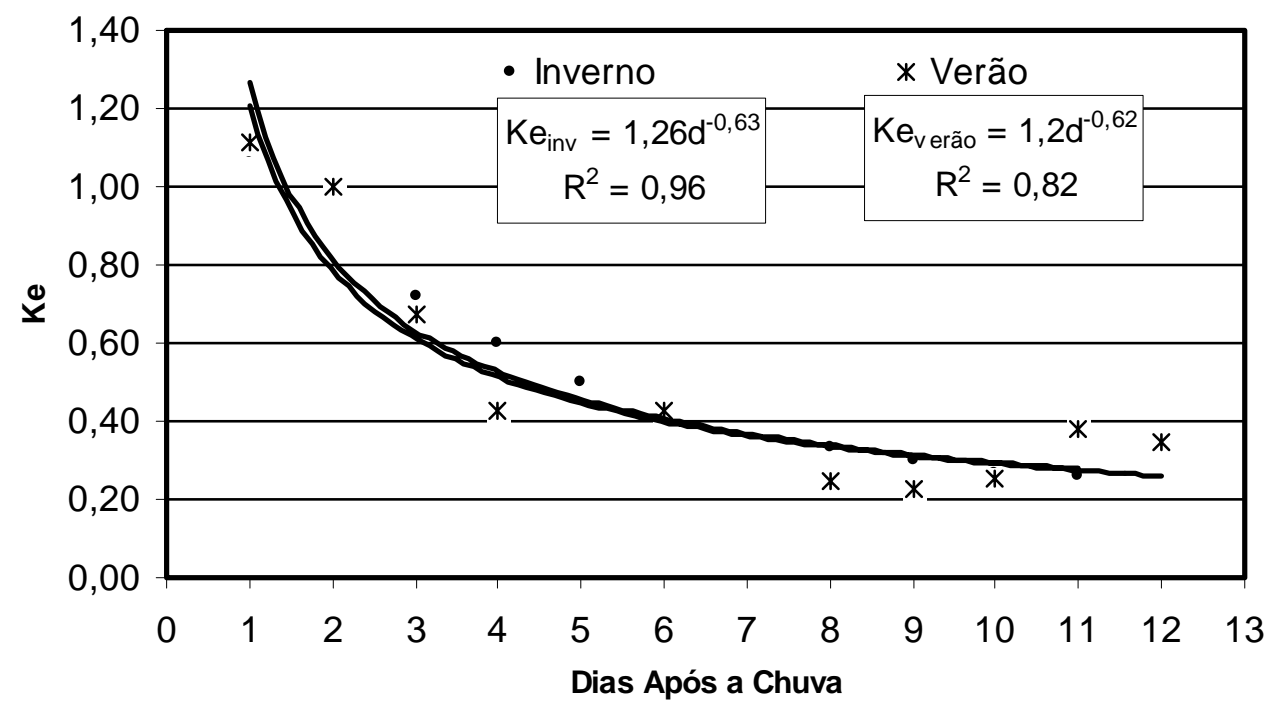

Figura 6 - Curvas de evaporação do solo $(K e)$ em função da ETo e do número de dias após a chuva $(d)$ para o inverno e verão

\subsection{Conclusões}

No período de verão a média de $E T c$ foi de $1,50 \mathrm{~mm} \mathrm{dia}^{-1}$ decrescendo a $0,66 \mathrm{~mm}$ $\mathrm{dia}^{-1}$ nos meses de inverno. Os valores obtidos de $K c$ foram de 0,36 para o verão e 0,22 para o inverno, representando uma redução maior que $50 \%$ na ETc no sentido verãoinverno.

A ETc horária também apresentou variações distintas para os períodos analisados. A $E T C$ máxima para o período de inverno ocorreu às 12:00 horas e para o verão às 14:00 horas. 
A evaporação do solo no período noturno foi semelhante em ambos os períodos estudados e representou $17,4 \%$ e $13,4 \%$ para o período de inverno e verão respectivamente. 


\section{LIMITE CRÍTICO DA ÁGUA DISPONÍVEL DO SOLO PARA A EVAPOTRANSPIRAÇÃO, TROCAS GASOSAS E POTENCIAL DE ÁGUA NA FOLHA EM LIMEIRA ÁCIDA ‘TAHITI’ SOB CONDIÇÕES DE CAMPO}

\section{Resumo}

O conhecimento do limite crítico de água disponível no solo é uma importante ferramenta para o manejo racional da irrigação. Um experimento foi conduzido com plantas de limeira ácida 'Tahiti' (Citrus latifolia) para analisar o efeito do esgotamento da água disponível no solo na evapotranspiração $(E T c)$, transpiração $(E)$, potencial de água na folha ao amanhecer $\left(\Psi_{P}\right)$ e ao meio-dia $\left(\Psi_{M}\right)$, condutância estomática $(g s)$ e assimilação líquida de $\mathrm{CO}_{2}(A)$. As plantas foram espaçadas de 7 x 4 m e irrigadas por 4 gotejadores, sendo a diminuição da água disponível no solo $(A D)$ provocada pela suspensão da irrigação (40 dias). Para a determinação da ETc foi utilizado um lisímetro de pesagem e para as medidas fisiológicas foram utilizados uma câmara de pressão ( $\Psi_{P}$ e $\Psi_{M}$ ) e analisador de gases por infra-vermelho ( $A, E$ e $\left.g s\right)$. A umidade $(\theta)$ e potencial matricial do solo $\left(\Psi_{S}\right)$ foram monitoradas por sondas de TDR e tensiômetros, respectivamente, instalados a 0,3, 0,6 e 0,9 m de profundidade Os elementos meteorológicos foram monitorados por uma estação agrometeorológica automática presente na área. Os resultados indicaram que o limite de $A D$ na qual a $E T c$ diminuiu foi de $43 \%$, ao passo que para $g s, A, E$ e $\Psi_{P}$ foi de $60 \%$. Ainda, o $\Psi_{P}$ foi mais sensível a $A D$ do que as medidas de $\Psi_{M}$ podendo ser recomendado como ferramenta para manejo de irrigação desde que uma das primeiras respostas fisiológicas ao déficit hídrico é o decréscimo do potencial de água no folha com conseqüente redução de $g s, A$ e $E$. No momento em que $A D$ estava ao redor de $60 \%$, o valor de $\Psi_{P}$ era $-0,62 \mathrm{MPa}$. 


\section{Summary}

The knowledge of the threshold level of available soil water content is an important tool for rational irrigation scheduling. An experiment was carried out with 'Tahiti' acid lime trees (Citrus latifolia) to evaluate the effects of available soil water depletion on evapotranspiration $(E T c)$, transpiration $(E)$, leaf water potential at predawn $\left(\Psi_{P}\right)$ and midday $\left(\Psi_{M}\right)$, stomatal conductance $(g s)$ and net $\mathrm{CO}_{2}$ assimilation $(A)$. The trees were spaced 7 x $4 \mathrm{~m}$ apart and drip-irrigated by four drippers being the available soil water content ( $A W C$ ) depleted by suspension of irrigation (40 days). Physiological parameters were measured with a pressure chamber $\left(\Psi_{P}\right.$ and $\left.\Psi_{M}\right)$ and an infrared gas analyzer ( $E$, gs and $A$ ). The evapotranspiration was determinated by a weighing lysimeter. The soil water content and potential $\left(\Psi_{S}\right)$ were monitored by TDR probes and tensiometers, respectively, installed at $0.3,0.6$ and $0.9 \mathrm{~m}$ depth. The meteorological elements were monitored by an automatic weather station present in the experimental area. The threshold level for the onset of ETc decline was 43\%, whereas it level was $60 \%$ of $A W C$ for $g s, A, E$ and $\Psi_{P}$. Also, $\Psi_{P}$ was more sensitive to $A W C$ than $\Psi_{M}$, being recommended as an irrigation schedule management tool since one of the first physiological responses to water deficit is the lowering of leaf water potential with consequent reduction of $g s, A$ and $E$. By the time $A W C$ was around $60 \%$, the value of $\Psi_{P}$ was $-0.62 \mathrm{MPa}$.

\subsection{Introdução}

A escassez mundial de água aliada ao custo dos sistemas de irrigação tem levado ao desenvolvimento de métodos de irrigação que minimizem o uso de água via maximização de sua eficiência (Jones, 2004). Nesse contexto, a irrigação localizada (microaspersão e gotejamento) tem assumido importante papel na redução do volume de água aplicado (Folegatti et al., 2004). Entretanto, a máxima eficiência na irrigação é dependente do manejo, cuja melhoria e novos métodos são necessários. 
O manejo da irrigação baseado no status da água no solo (seja pelo teor ou pelo potencial da água do solo) é um dos métodos mais utilizados dado a sua praticidade, baixo custo e por possibilitar o acoplamento de sensores em sistemas automáticos de aquisição de dados. O principio do manejo é que a umidade do solo pode decrescer até um determinado valor em que a água se torna menos disponível ou mesmo indisponível para as plantas, iniciando o processo de estresse hídrico dependendo da espécie considerada (Allen et al., 1998).

As plantas cítricas apresentam mudanças significativas no potencial da água na folha diariamente (Syvertsen \& Albrigo, 1980), acontecendo com mais intensidade sob condições de estresse hídrico. A redução do status de água na planta induz ao fechamento estomático, um mecanismo bem conhecido para prevenção da desidratação sob ambientes limitantes (Syvertsen, 1982) e cujos efeitos na transpiração e fotossíntese das espécies cítricas depende do nível de estresse (Vu \& Yelenosky, 1988 e Medina et al., 1998, 1999). Alguns autores verificaram redução tanto na condutância estomática como na assimilação de $\mathrm{CO}_{2}$ mesmo sob moderado nível de estresse hídrico (Davies \& Albrigo, 1994 e Medina et al., 1999). O mecanismo envolvido nesta sensibilidade ao estresse hídrico envolve aspectos químicos e hidráulicos (Liu et al., 2003 e Streck, 2004). O primeiro é baseado na síntese de ácido abscísico (ABA) nas raízes sob solo seco com posterior transporte para os ramos via xilema (Davies \& Zhang, 1991 e Liu et al., 2003) e redução da condutância estomática ao passo que o segundo é baseado na mudança na pressão hidrostática que leva a síntese de ABA nas folhas (Liu et al., 2003). Como uma conseqüência do estresse hídrico, ocorre a redução da divisão celular e crescimento foliar (Taiz \& Zeiger, 2004 e Hsiao, 1993).

Normalmente, os limites críticos da água disponível no solo $(A D)$ são obtidos através de experimentos de longa duração, comparando-se a produtividade ou dados de crescimento da planta com umidade umidade do solo para uma específica região edafoclimática (Davies \& Albrigo, 1994). Allen et al. (1998) recomenda como nível crítico um esgotamento de $50 \%$ da $A D$, considerando uma planta de citros com $20 \%$ de cobertura do solo, com 0,8 a $1,1 \mathrm{~m}$ de profundidade do sistema radicular e sob uma 
evapotranspiração de referência de 5 mm dia ${ }^{-1}$. Na Flórida, Marler \& Davies (1990), trabalhando com plantas de laranjeira 'Hamilin', recomendam um esgotamento máximo de 30 a 45\% da AD para a obtenção de ótimos níveis de crescimento em plantas jovens. Trabalhos recentes sugerem limites diferentes em função dos estádios fenológicos da planta cítrica (Domingo et al., 1996; Ginestar \& Castel, 1996; González-Altozano \& Castel, 2000a e Davies \& Zalman, 2000).

Na realidade, o limite de água disponível é uma função do tipo de cultura e do consumo de água nos diferentes estádios fenológicos, solo e clima (Davies \& Albrigo, 1994 e Pereira et al., 2002). Tal variabilidade enfatiza a importância de se determinar valores regionalizados de limite de água disponível. Davies \& Albrigo (1994) argumentam que para uma maior acurácia estes valores deveriam ser relacionados usando características como condutância estomática, potencial de água na folha ou fruto e assimilação de $\mathrm{CO}_{2}$.

Em experimento conduzido em vasos, Machado et al. (1999) verificaram que não houve redução na fotossíntese e no conteúdo relativo de água nas folhas enquanto a disponibilidade hídrica do substrato de laranjeiras 'Valência' enxertadas sobre ‘Trifoliata' ou limoeiro ‘Cravo’ estava entre de 24\% e 15\%. Entretanto, são escassos os trabalhos conduzidos sob condições de campo.

Normalmente, o início das irrigações no Estado de São Paulo coincide com o final do período de inverno, considerado seco. O manejo adequado da irrigação torna-se imprescindível quando se deseja evitar a ocorrência de estresse hídrico, especialmente no florescimento, período claramente reconhecido como o mais sensível à falta de água, afetando de forma predominante a produção. (Doorenbos \& Kassam, 1994 e Ginestar \& Castel, 1996).

Diante do exposto, o objetivo deste trabalho foi verificar os efeitos do esgotamento da água disponível no solo na evapotranspiração, transpiração, condutância estomática, 
assimilação de $\mathrm{CO}_{2}$ e potencial de água na folha em plantas de limeira ácida 'Tahiti' no final do período de inverno.

\subsection{Material e Métodos}

\section{Características da área experimental}

O experimento foi realizado na Fazenda Areão da Escola Superior de Agricultura “Luiz de Queiroz” - ESALQ/USP, em Piracicaba, SP (2241'58”S e 47³8’0”O, 511 m de altitude). A temperatura média anual é de $21,4^{\circ} \mathrm{C}$, e o total anual de chuva é de 1257 mm. O experimento foi conduzido entre o término do inverno e início da primavera de 2004 (durante 40 dias, de 15/08/2004 a 24/09/2004). A temperatura, umidade relativa média do ar e o total de precipitação pluviométrica durante a condução do experimento foram de $22,3^{\circ} \mathrm{C}, 60,9 \%$ e $8,5 \mathrm{~mm}$, respectivamente. O solo da área experimental é classificado como Nitossolo vermelho segundo a classificação brasileira de solos (Embrapa, 1999). A capacidade de água disponível no solo foi de $125 \mathrm{~mm} \mathrm{~m}^{-1}$ para uma densidade média do solo de $1300 \mathrm{~kg} \mathrm{~m}^{-3}$. Estes valores foram determinados em amostras indeformadas coletadas de trincheiras, em três locais da área, retiradas a cada 0,2 m até 1,0 m de profundidade.

As limeiras ácidas 'Tahiti' (Citrus latifolia Tanaka), enxertadas sobre plantas de citrumeleiro 'Swingle' [Poncirus trifoliata (L.) Raf. x C. paradisi Macf.], foram plantadas em sulcos na primeira quinzena de maio de 2001 no espaçamento $7 x 4 m$, obtendo-se um total de 322 plantas em uma área experimental de aproximadamente 1 ha, sendo a calagem e adubação realizadas de acordo com Raij et al. (1992). Os tratos culturais consistiram de pulverizações com defensivos e roçagens. O sistema de irrigação utilizado no pomar foi o gotejamento, com quatro emissores autocompensantes por planta apresentando vazão de $4 \mathrm{~L} \mathrm{~h}^{-1}$ cada. De acordo com Zocoler (2003) o coeficiente de uniformidade foi de 95\%. A irrigação foi automaticamente controlada por um painel eletrônico conectado a uma válvula de comando hidráulico. A porcentagem da 
área molhada em relação à área de projeção da copa, medida a 0,3 m de profundidade e sob 3 horas de irrigação, foi de $22 \%$.

\section{Medidas lisimétricas}

Para determinação da evapotranspiração da cultura (ETc) foi utilizado um lisímetro de pesagem, constituído por três células de carga com disposição triangular, formando um ângulo de $120^{\circ}$ entre elas, acopladas a um sistema automático de coleta de dados "data logger" (modelo CR23X da Campbell Scientific ${ }^{1}$, Logan, UT, EUA) e localizado no centro da área experimental contendo uma planta com as mesmas características fitométricas e sob o mesmo sistema de manejo das demais. Este lisímetro apresentava as dimensões de $4 \mathrm{~m}$ de diâmetro e 1,3 m de profundidade (1,0 m útil). Maiores detalhes sobre construção e calibração desse equipamento podem ser obtidos em Campeche (2002).

No dia 02/05/2004 o lisímetro foi re-calibrado com pesos padrões (10 e 20 kg) (Figura 1A). Resumidamente, o processo da calibração foi realizado a noite (22:00h) a fim de evitar uma possível mudança de massa do sistema devido à evaporação da água do solo. Inicialmente, foi registrado milivoltagem média do sistema, sem adição de pesos, teoricamente descarregado. Em intervalos de dois minutos foram adicionados os pesos. O primeiro minuto da medida foi descartado para análise, já que inclui as oscilações provocadas pelo acréscimo e decréscimo do peso. Em seguida foram retirados os pesos em intervalos também de dois minutos na mesma seqüência da sua adição. Desta maneira, foi feita uma relação linear entre o somatório das saídas de sinal das três células de carga e a massa adicionada, em equivalente de quilograma de água (mV x kg). Pelos resultados obtidos (Figura 1B) verifica-se uma excelente linearidade e baixa histerese com uma exatidão de 0,82 kg.

\footnotetext{
${ }^{1}$ Referências à marca registrada não constituem endosso por parte do autor.
} 


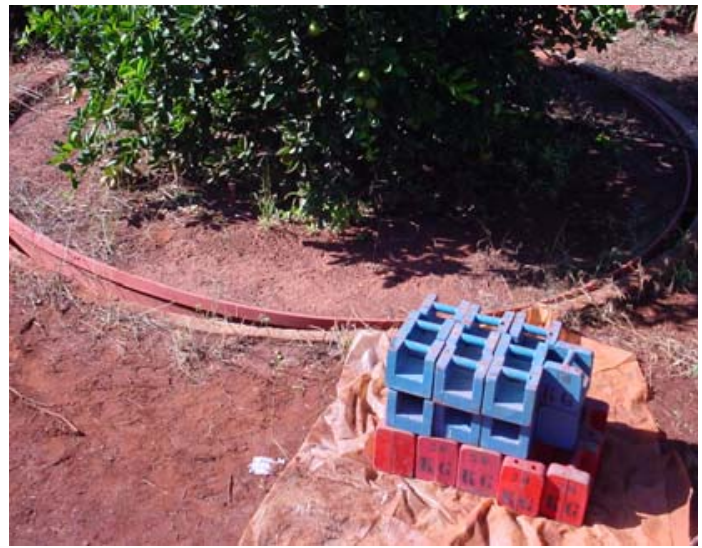

A

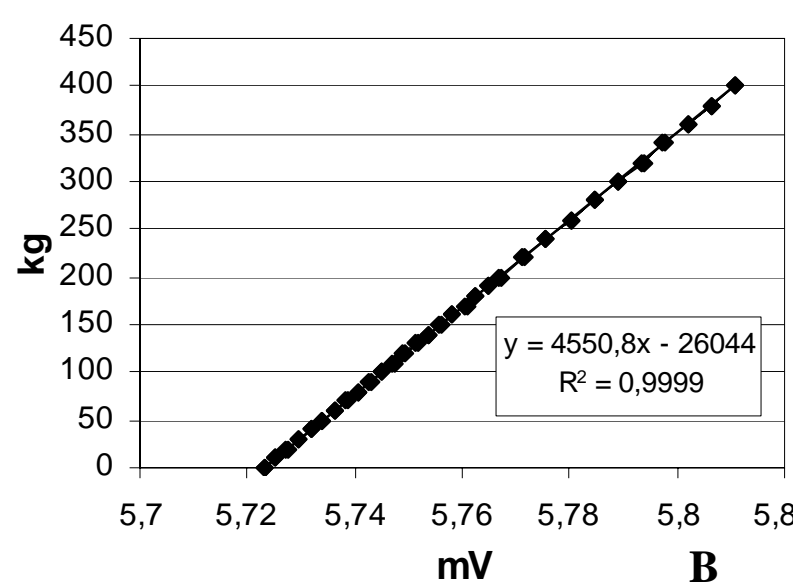

B

Figura 1 - Pesos utilizados na re-calibração do lisímetro (A) e regressão verificada com a adição e subtração dos pesos, kg e a milivoltagem, $\mathrm{mV}$ (B)

Para o cálculo da ETc diária foi considerada a diferença dos valores registrados a meia-noite entre dois dias consecutivos, quando o elemento meteorológico vento era nulo ou fraco $\left(<1,5 \mathrm{~m} \mathrm{~s}^{-1}\right)$. Finalmente, os valores em quilograma foram convertidos em milímetros de água considerando a área útil de cada planta $\left(28 \mathrm{~m}^{2}\right)$.

Na área experimental foram escolhidas, ao lado do lisímetro, 6 plantas de tamanho similar e dividida em 2 grupos, irrigadas $(X)$, com reposição diária da água evapotranspirada e não-irrigadas $(Y)$, com suspensão da irrigação. Para certificação da similaridade entre plantas foi realizada uma avaliação fitométrica no dia 09/08/2004 consistindo de medidas de altura, perímetro do caule $(0,05 \mathrm{~m}$ acima do ponto de enxertia) e diâmetro da copa (Tabela 1). O volume da copa foi calculado usando o procedimento descrito por Hutchinson (1977). 
Tabela 1. Medidas fitométricas das plantas de limeira ácida 'Tahiti’ em condições de campo (09/08/2004)

\begin{tabular}{ccccc}
\hline Planta & Altura & $\begin{array}{c}\text { Diâmetro da } \\
\text { copa } \\
\mathbf{( m )}\end{array}$ & $\begin{array}{c}\text { Perímetro do } \\
\text { caule }\end{array}$ & $\begin{array}{c}\text { Volume da } \\
\text { copa } \\
\mathbf{( m}^{3} \mathbf{)}\end{array}$ \\
\hline Irrigadas $X^{1}$ & $3,25 \pm 0,23$ & $3,59 \pm 0,06$ & $0,35 \pm 0,02$ & $10,47 \pm 0,62$ \\
Não-irrigadas $Y^{1}$ & $3,32 \pm 0,13$ & $3,63 \pm 0,08$ & $0,34 \pm 0,03$ & $10,90 \pm 0,71$ \\
Lisímetro & 3,05 & 3,60 & 0,32 & 9,88 \\
\hline
\end{tabular}

1 Valores médios de 3 plantas. \pm desvio-padrão

Estimativa da água disponível no solo

A cada três dias foi medida a umidade do solo $(\theta)$ em $X$ e $Y$ por meio de sondas de TDR e um testador de cabos (modelo 1502C Tektronix ${ }^{1}$, Beaverton, OR, EUA) (Figura 1), instaladas a 0,3 0,6 e 0,9 m em três repetições por tratamento. Cada sonda foi instalada sob a área de molhamento do gotejador, abaixo da copa da planta e na face Norte. A constante dielétrica aparente $(\mathrm{Ka})$ foi convertida em umidade volumétrica com base na equação de calibração encontrada por Tommaselli \& Bacchi (2001). Foi considerado o valor médio a partir das leituras nas três profundidades. No lisímetro, para monitorar a umidade diariamente, foram utilizados sensores eletrônicos de potencial matricial do solo, $\Psi_{S}$ (Watermark modelo 253-L - Campbell Scientific ${ }^{1}$, Logan, UT, EUA), instalados nas mesmas profundidades usada para as sondas de TDR. Os valores de potencial foram convertidos em umidade volumétrica pelo programa computacional Soil Water Retention Curve usando o modelo matemático de Genuchten (1980).

A porcentagem de água disponível $(A D)$ foi calculada segundo a equação (1):

$$
A D=\left[\frac{(\theta a-\theta p m p)}{(\theta c c-\theta p m p)}\right] \times 100
$$

em que: 
$A D$ - Porcentagem de água disponível no solo, \%

$\theta c c$ - Umidade do solo na capacidade de campo, $\mathrm{m}^{3} \mathrm{~m}^{-3}(-10 \mathrm{kPa})$

$\theta p m p$ - Umidade do solo no ponto de murcha, $\mathrm{m}^{3} \mathrm{~m}^{-3}(-1500 \mathrm{kPa})$

$\theta a$ - Umidade média atual do solo no perfil do solo $(0-0,9 \mathrm{~m}), \mathrm{m}^{3} \mathrm{~m}^{-3}$

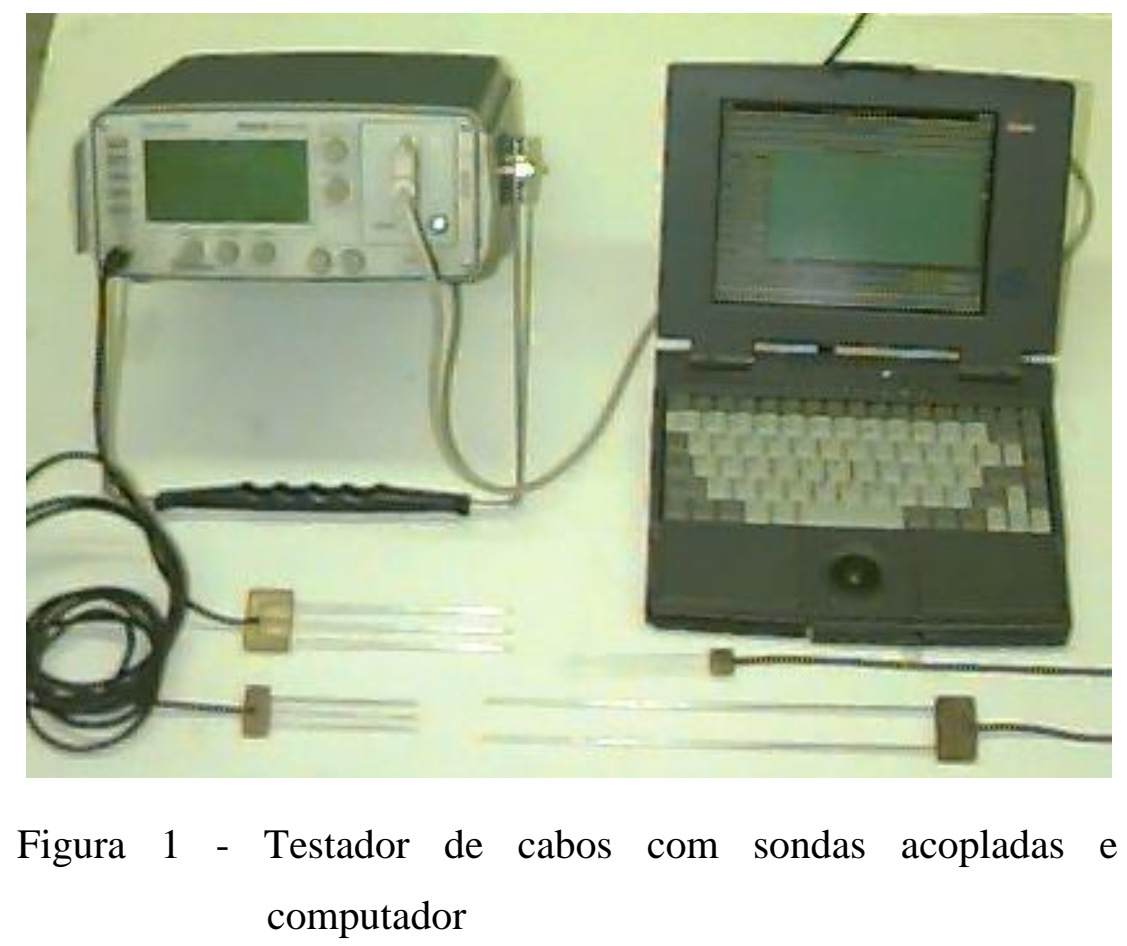

Medidas do potencial de água na folha

O potencial de água na folha foi medido a cada três dias no amanhecer ( $\Psi_{P}$, 06:00-06:30 horas) e ao meio-dia ( $\left.\Psi_{M}, 12: 00-12: 30 \mathrm{~h}\right)$ com uma câmara de pressão (modelo 3005, Soil Moisture Equipment Corporation $^{1}$, Santa Bárbara, CA, EUA) (Figura 2A). Em cada avaliação dois brotos desenvolvidos e com 4 a 8 folhas foram amostrados por planta, escolhidos na porção média da copa da planta. 
Medidas de trocas gasosas

Duas folhas completamente expandidas por planta em cada tratamento, posicionadas externamente na copa foram usadas para as medidas de trocas gasosas. A assimilação de $\mathrm{CO}_{2}(A)$, transpiração $(E)$ e condutância estomática ( $\left.g s\right)$ foram determinadas a cada três dias, às 09:30-10:30 h, usando um analisador de gases por infravermelho (modelo LI-6400, Licor ${ }^{1}$, Lincoln, NE, EUA) (Figura 2B) nos mesmos dias usados para medidas de potenciais da água na folha e solo. A radiação fotossinteticamente ativa $(R F A)$ foi fixada no valor lido no início das medidas, conforme as condições naturais de radiação. Durante as medidas a concentração de $\mathrm{CO}_{2}$ foi mantida entre $350 \pm 10 \mu \mathrm{mol} \mathrm{mol}{ }^{-1}$. A eficiência do uso de água (EUA) foi calculada como $A / E$ (Machado et al., 1999).
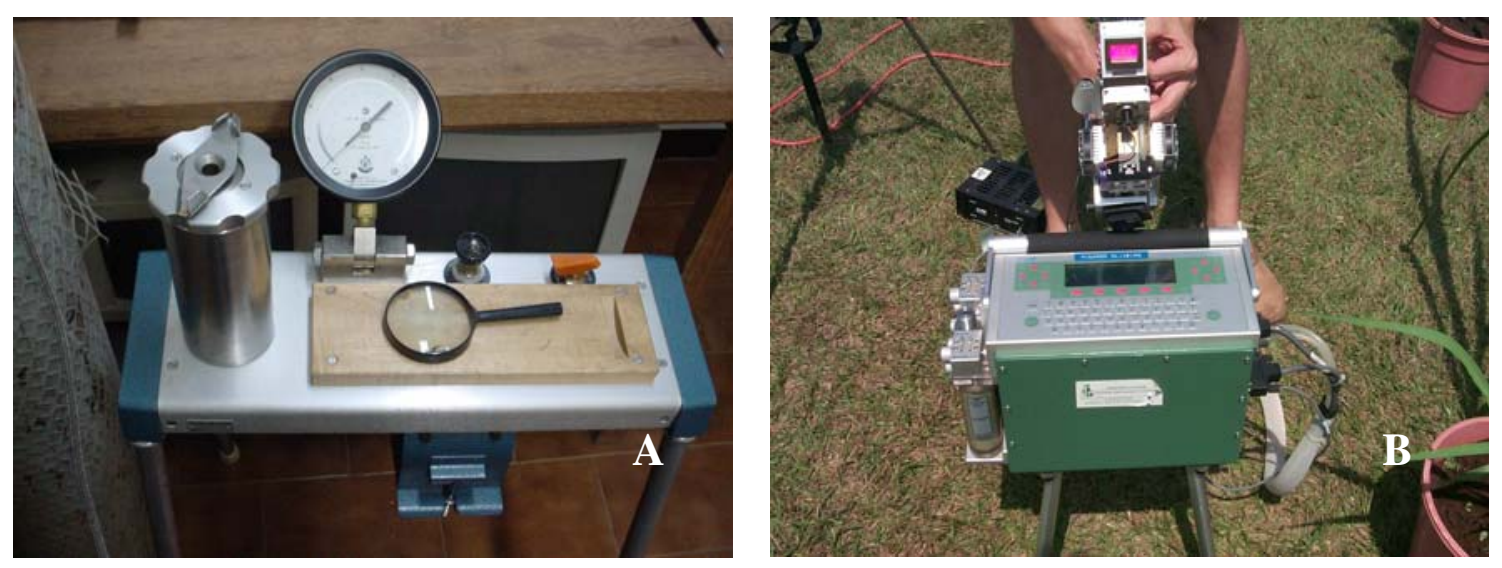

Figura 2 - Câmara de pressão (A) e analisador portátil de gases por infravermelho (B)

Determinando o limite crítico para água disponível no solo

A ETo e os elementos meteorológicos foram obtidos com uma estação automática (modelo CR 21X, Campbell Scientific ${ }^{1}$, Logan UT, EUA) que continha sensores de temperatura e umidade relativa do ar, radiação global e líquida, velocidade do vento além de estar programada para calcular a ETo segundo o método de Penman-Monteith parametrizado por Allen et al. (1998). 
Previamente, 15 dias antes do início do déficit (01/08 a 15/08/2004), o lisímetro foi irrigado diariamente, visando à reposição da evapotranspiração do dia anterior e a manutenção da umidade do solo próxima à capacidade de campo. Desta maneira determinou-se à relação entre a ETc e a evapotranspiração de referência (ETo) obtendose um coeficiente de 0,4. Este coeficiente foi utilizado para cálculo da irrigação das plantas do tratamento irrigado $(X)$, acrescentando-se $25 \%$ em volume para assegurar que as plantas deste tratamento não teriam nenhuma restrição hídrica. Durante este período não ocorreu nenhuma precipitação pluviométrica, a temperatura média diária e a umidade relativa do ar foram de $17,4^{\circ} \mathrm{C}$ e $66,7 \%$, respectivamente.

A suspensão da irrigação no tratamento com déficit hídrico $(Y)$ e lisímetro ocorreram no dia 16/08/2004. A partir de então, a evapotranspiração obtida pelo lisímetro foi denominada como evapotranspiração real $\left(E T_{R}\right)$ e comparada com o valor obtido antes do início do tratamento $(0,4 \times E T o)$. No momento em que a relação diminuiu $\left(E T_{R} / E T c<1,0\right)$ estabeleceu-se assim, o limite da porcentagem da água disponível no solo em função da evapotranspiração. De maneira análoga, os valores médios obtidos para $A, E, \Psi_{P}, \Psi_{M}$ nas plantas não-irrigadas $(Y)$ foram relacionados com as plantas com irrigação diária $(X)$ e o limite crítico para $A D$ foi então determinado com base nesses parâmetros.

\subsection{Resultados e Discussão}

\section{Evapotranspiração}

A evolução da estimativa da evapotranspiração $(E T c)$ e a real $\left(E T_{R}\right)$ durante o período de secamento do solo está ilustrado na Figura 3A. Ambas mostraram uma tendência de aumento a partir do inicio do experimento com exceção de dois picos (dias 13 e 33) que foram causados pela diminuição da radiação e déficit de pressão de saturação do ar (Figura 4A e B). A relação entre $E T_{R} / E T c$ foi quase constante, variando próximo de 1,0 enquanto a porcentagem de $A D$ era maior do que $43 \%$. Depois, a relação diminuiu claramente como mostrado na Figura 3B. Este resultado está próximo aos 46\% 
recomendado Allen et al. (1998) como limite crítico da água disponível sob condições ambientais e estádio fenológico da cultura semelhantes. No entanto, é inferior aos valores recomendados por Marler \& Davies (1990) com 65 a 70\%. Quando a porcentagem de água disponível estava próxima de $43 \%$, os valores de potenciais da água na folha ao amanhecer e solo eram de -0,79 MPa e -82,1 $\mathrm{kPa}$ (a 0,6 $\mathrm{m}$ de profundidade) respectivamente, que poderia estar indicando certo nível de estresse se comparados como os resultados obtidos por Vu \& Yelenosky (1988) e Machado et al. (2002). Pires (1992) sugere iniciar as irrigações quando $\Psi_{S}=-50 \mathrm{kPa}$. Medina \& Machado (1998) não verificaram decréscimos na assimilação de $\mathrm{CO}_{2}$, transpiração e eficiência de uso de água, potencial de água na folha e conteúdo relativo de água na folha em laranjeiras 'Valência' quando o potencial de água no substrato foi maior do que -40 kPa. A respeito do potencial de água na folha, Shalhevet \& Levy (1990) relataram que o $\Psi_{P}$ deve ser mantido superior a -0,72 MPa para evitar o estresse hídrico, porém com grande variabilidade entre as espécies.

Aos 34 dias após o inicio da suspensão da irrigação, a planta do lisímetro mostrou uma clorose generalizada e $\Psi_{P}=-2,70 \mathrm{MPa}$, que implicou na re-irrigação (18/09/2004) somente para a planta do lisímetro. Mesmo após o retorno das irrigações a relação entre $E T_{R} / E T c$ permaneceu abaixo de 1,0 até o final do período experimental. Ginestar \& Castel (1996) verificaram que foram necessárias duas semanas de irrigação para uma hidratação das plantas submetidas ao estresse hídrico severo ( $\left.\Psi_{P}=-4,0 \mathrm{MPa}\right)$ sob condições de campo. Medina et al. (1999) argumentam que houve somente uma recuperação parcial da abertura estomática em plantas estressadas de laranjeira 'Valência' depois da re-irrigação. Este atraso na reabertura pode estar associado ao acúmulo de ácido abscísico durante o esgotamento da água disponível (Davies \& Zhang, 1991 e Liu et al., 2003) ou então a danos nos processos bioquímicos e/ou fotoquímicos da fotossíntese, a qual reduz a condutância estomática via aumento da concentração intercelular de $\mathrm{CO}_{2}$ (Wong et al., 1979). 


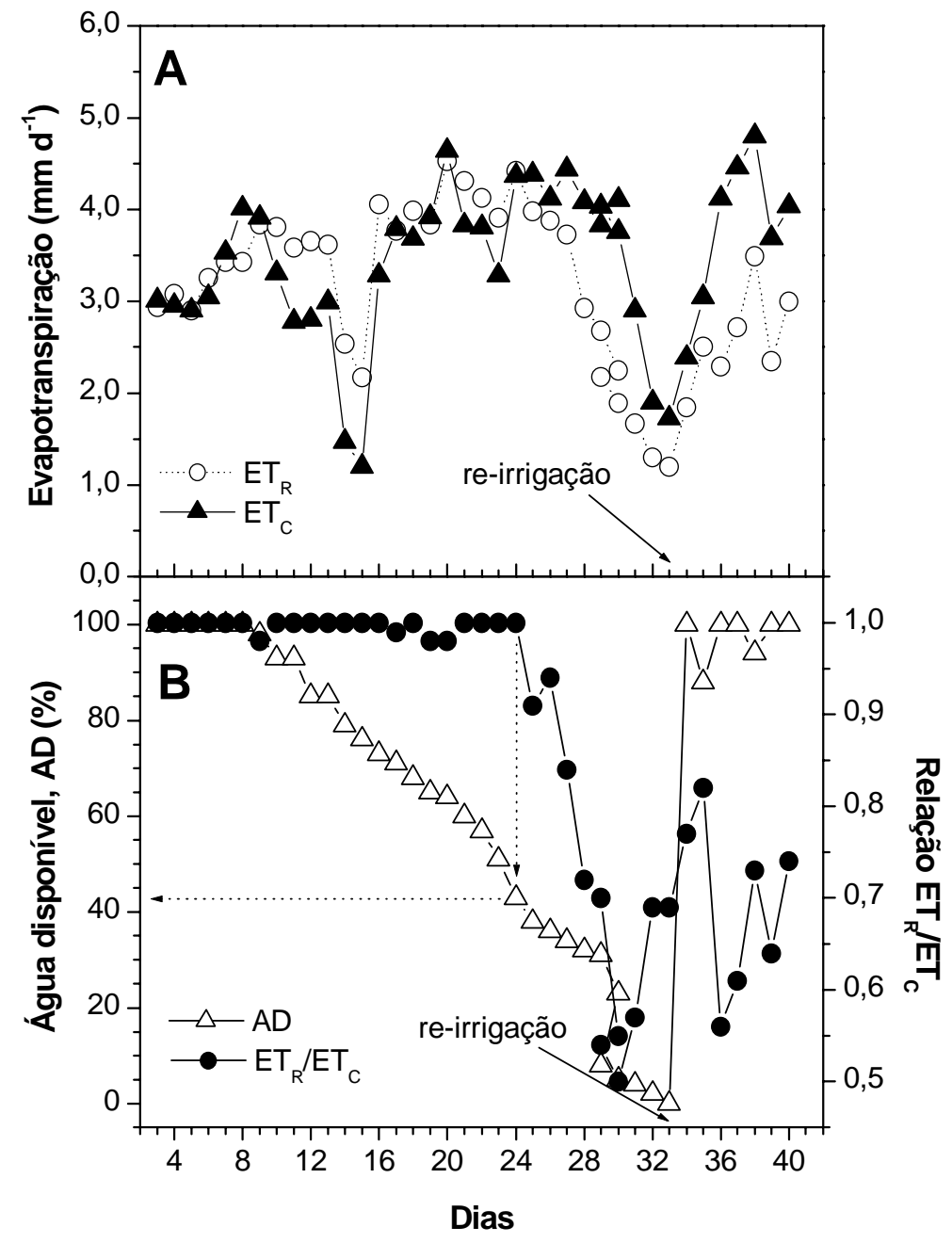

Figura 3 - Evolução da estimativa da evapotranspiração da cultura (ETc) e evapotranspiração real (ETr) a partir da suspensão das irrigações (A). Evapotranspiração relativa $(E T r / E T c)$ e a porcentagem da água disponível $(A D)$ no solo ao longo do período experimental. A seta indica o retorno das irrigações (B) 


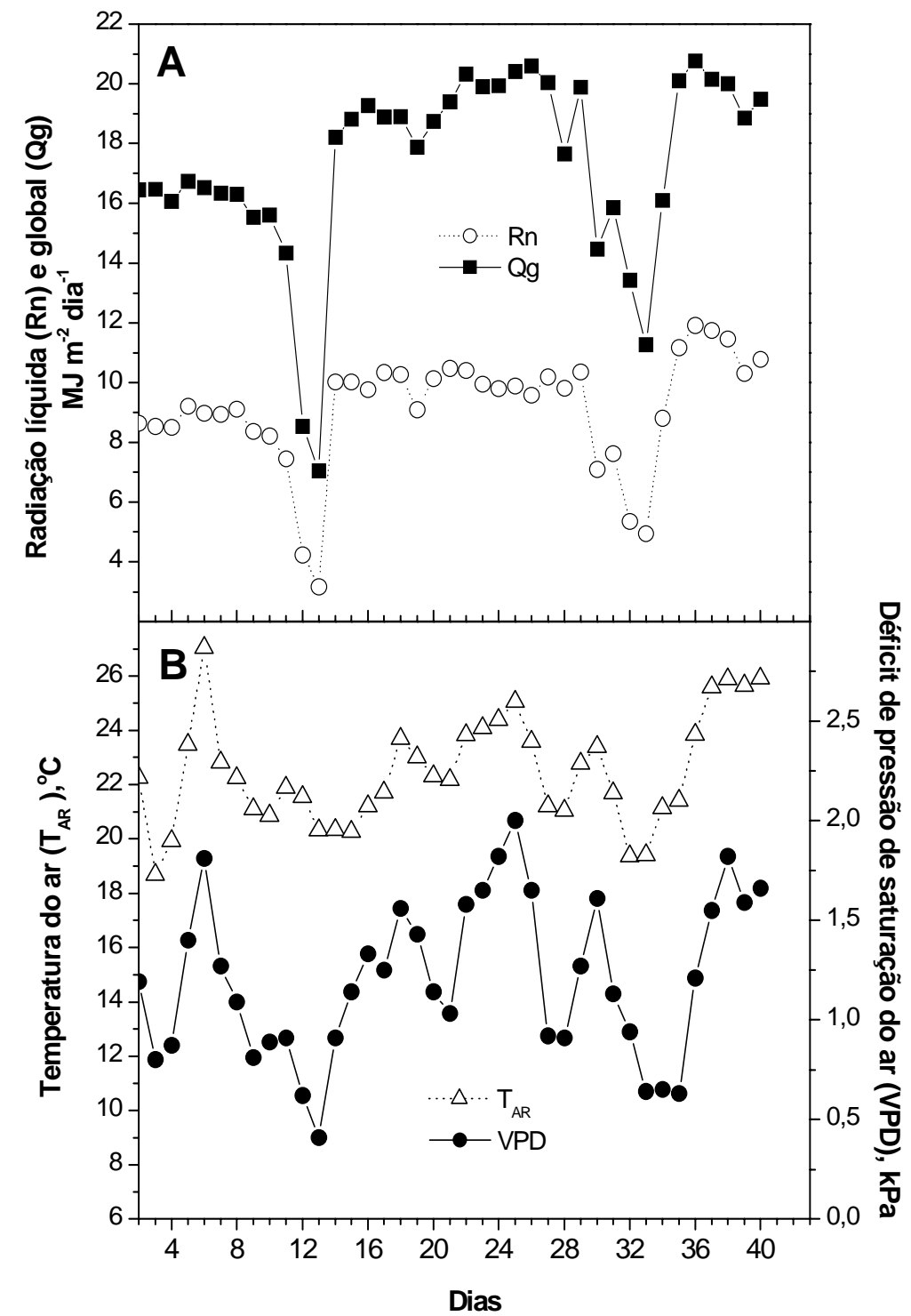

Figura 4 - Evolução da radiação global $(R g)$, líquida $(R n)(\mathrm{A})$, temperatura e déficit de pressão de saturação do ar (VPD) durante o período experimental (B) 
Trocas gasosas

A Figura 5 (A, C e E) apresenta a evolução da assimilação de $\mathrm{CO}_{2}(A)$, condutância estomática $(g s)$ e transpiração $(E)$ das plantas irrigadas $(X)$ e não-irrigadas (Y) durante o período de esgotamento da água disponível. Os valores médios para $A, g s$, $E$ nas plantas irrigadas variaram de 4 a $7 \mu \mathrm{mol} \mathrm{m} \mathrm{m}^{-2} \mathrm{~s}^{-1}, 0,05$ a $0,11 \mathrm{~mol} \mathrm{~m}^{-2}, \mathrm{~s}^{-1}$ e 1,2 a 2,60 mmol m $\mathrm{m}^{-2}$, respectivamente. Estes valores foram menores do que aqueles relatados sob condições ambientais ótimas (Machado et al., 2002), especialmente para $A$, que normalmente varia entre 12 a $14,5 \mu \mathrm{mol} \mathrm{m} \mathrm{m} \mathrm{s}^{-1}$ (Medina, 2003). Estes valores inferiores provavelmente refletem as oscilações nos elementos meteorológicos, especialmente a radiação, temperatura, umidade relativa do ar, resultando em condições favoráveis ou não para trocas gasosas durante o período experimental. Além disso, o efeito sazonal nas trocas gasosas deve ser considerado, uma vez que Machado et al. (2002) verificou altas taxas fotossintéticas durante o verão comparativamente ao inverno.

A evolução entre as plantas não-irrigadas e irrigadas $(Y / X)$ com relação à $g s, A$ e $E$ está apresenta na Figura 5 (B, D e F). A relação foi inferior a 1,0 somente quando a $A D$ foi inferior a $60 \%$. Nesta ocasião, o valor médio de $\Psi_{P}$ era -0,62 MPa.

As trocas gasosas foram mais sensíveis ao esgotamento da $A D$ do que a evapotranspiração medida no lisímetro. Se a redução na condutância estomática afeta a diretamente a evapotranspiração, como isto poderia ser explicado? Uma possibilidade é que as medidas de trocas gasosas foram feitas em folhas localizadas externamente na copa, completamente expostas à radiação, uma condição menos favorável do que aquelas localizadas mais internamente. Na realidade, as folhas sombreadas apresentam maiores potenciais de água (Syvertsen et al., 1981), que permite uma maior abertura dos estômatos e conseqüentemente, transpiração. Com isso, poderia estar havendo uma compensação nas medidas feitas no lisímetro até $43 \%$ da $A D$.

A evolução da eficiência do uso da água (EUA) durante o esgotamento de $A D$ como também as relações entre $E U A_{Y} / E U A_{X}$ e $A D$ estão presentes na Figura 6 (A e B). Desde que não houve diferenças entre irrigadas e não irrigadas. A manutenção da $E U A$ nas plantas não-irrigadas provavelmente foi devido ao fechamento estomático a qual 
afeta mais a transpiração do que a fotossíntese (Kriedemann, 1981). Pode-se inferir que as plantas de limeira ácida 'Tahiti' apresentam mecanismos de controle estomático para a prevenção da desidratação e manutenção do status hídrico nos tecidos. De acordo com Brakke \& Allen Júnior (1995) não houve diferenças significativas em EUA de plantas cítricas mantidas a 37 e $56 \%$ de $A D$. A determinação do nível de esgotamento permissível de $A D$ baseado na relação $E U A_{Y} / E U A_{X}$ não foi possível pois a relação foi praticamente constante durante o período experimental. 

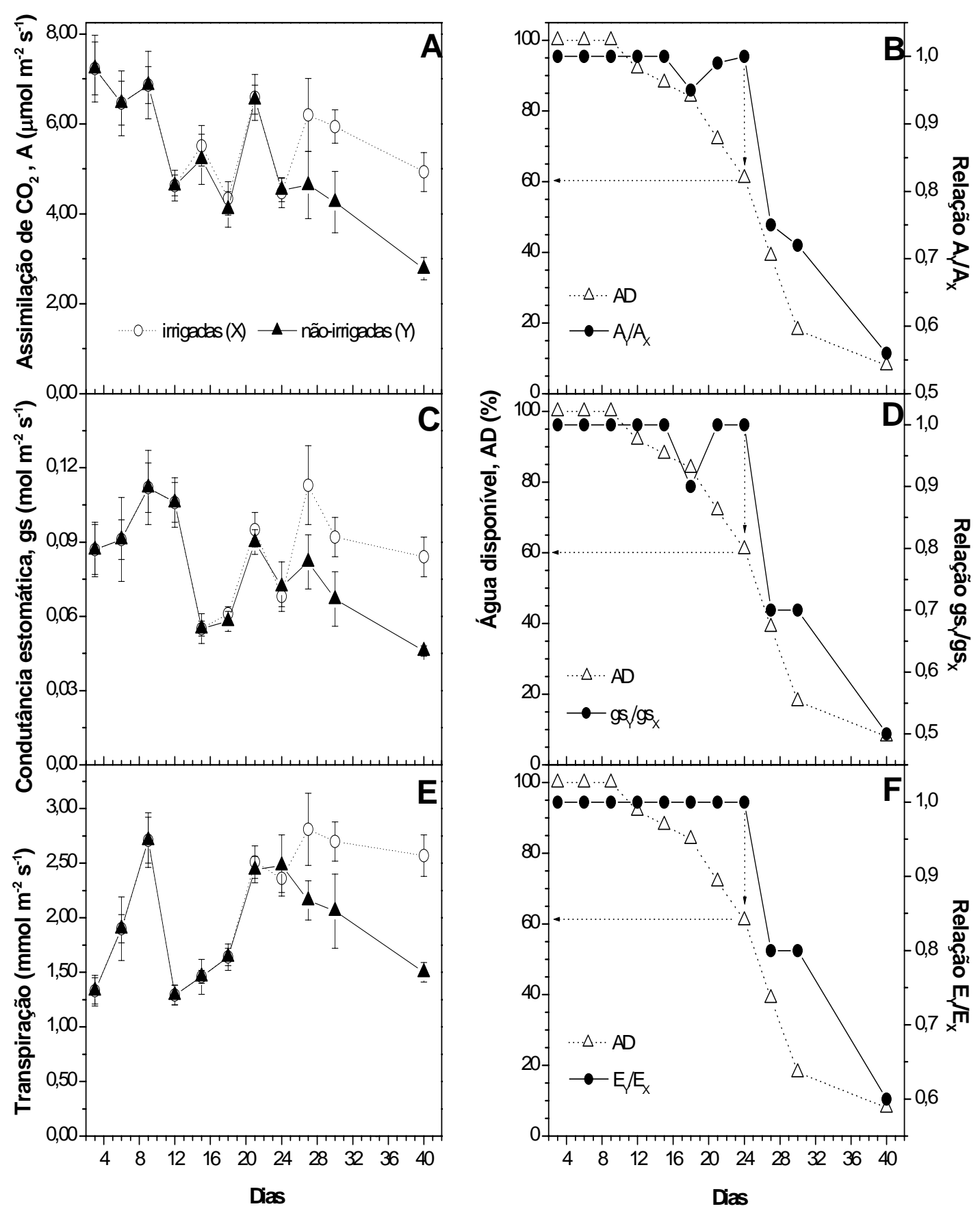

Figura 5 - Variação da assimilação de $\mathrm{CO}_{2}(A)$, condutância estomática $(g s)$ e transpiração $(E)$ nas plantas $(X)$ e $(Y)$ com a água disponível $(A D)$. Cada ponto representa o valor médio de 6 repetições ( \pm desvio-padrão) 

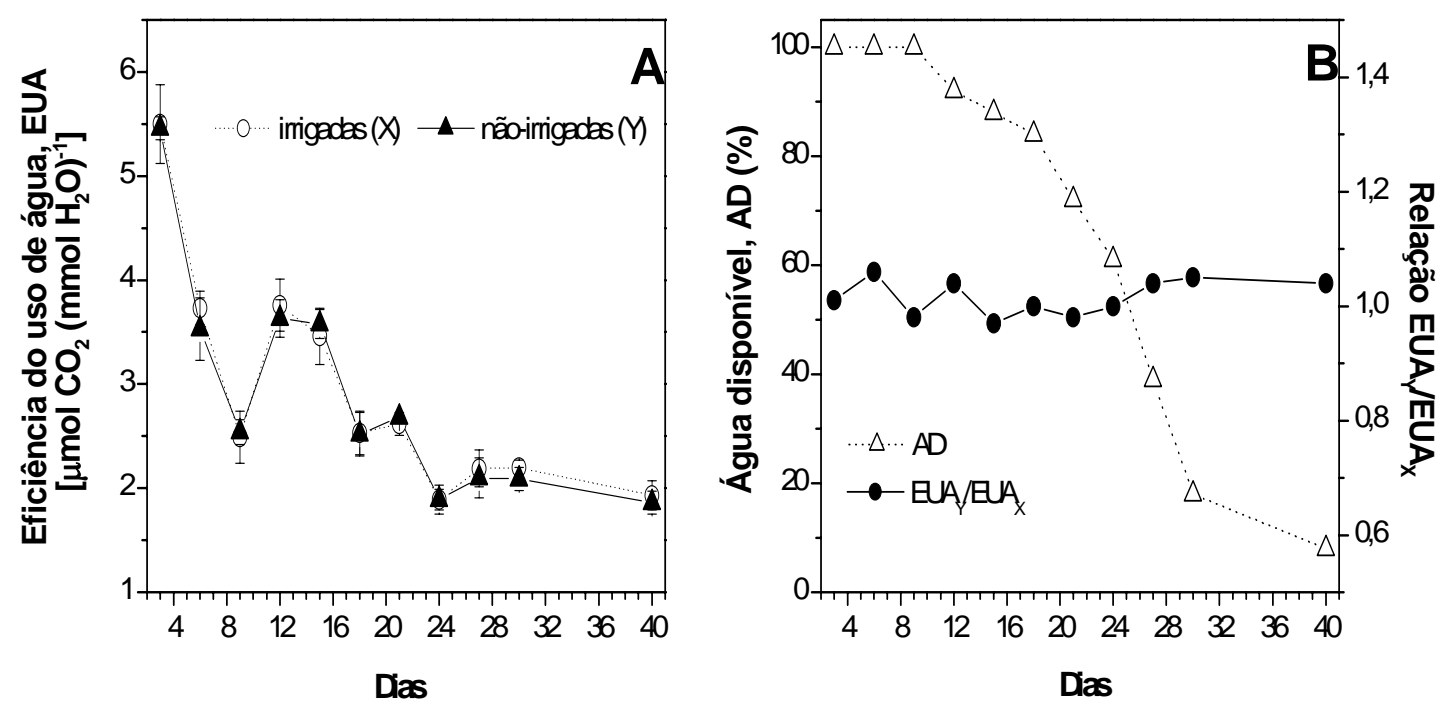

Figura 6 - Variação da eficiência do uso de água $(E U A)(\mathrm{A})$ e relação entre $E U A$ em plantas irrigadas $(X)$ e não-irrigadas $(Y)$ com a água disponível $(A D)(\mathrm{B})$. Cada ponto representa o valor médio de 6 repetições ( \pm desvio-padrão)

Potencial de água na folha

Aos 24 dias de déficit hídrico, $\Psi_{P}$ e $\Psi_{M}$ foram reduzidos com o $\Psi_{P}$ apresentando um queda significativa, atingindo o valor mínimo de -0,9 MPa (Figura 7A). Entretanto, o valor médio observado de $\Psi_{P}$ nas plantas irrigadas (-0,57 MPa) foram menores do que aqueles observados nas mesmas plantas no período do verão (-0,35 MPa, dados não apresentados). Duas hipóteses para a questão podem sugeridas sendo a primeira relacionada ao molhamento parcial do solo e conseqüentemente volume de raízes promovido pelo gotejamento. Bernardo (1995) e Vermeiren \& Jobling (1997) recomendam, para plantas perenes, molhar, em média, de $50 \%$ da zona radicular potencial. Em alguns trabalhos em experimentos de longo prazo com citros (Bielorai,1982; Samajstrla \& Koo, 1984; Castel, 1994 e Souza et al., 2003) verificou-se também, uma concordância em torno de 50\%. Entretanto, Gowing et al. (1990) encontraram redução na transpiração, expansão e iniciação foliar em plantas de macieira que tiveram $50 \%$ do sistema radicular molhado quando comparadas aquelas $100 \%$ molhadas. Este é um importante parâmetro a ser colocado em questão por ocasião do 
dimensionamento do projeto, uma vez que um aumento da área molhada implica em maiores custos na aquisição do sistema de irrigação. Uma vez que a temperatura do solo atingiu valores próximos de $7,5^{\circ} \mathrm{C}$, outra hipótese seria a tese de que a baixa temperatura do solo no inverno estaria dificultando a condutividade hidráulica das raízes e, conseqüentemente prejudicando a hidratação dos tecidos, conforme observou Elfving et al. (1972). Entretanto, Machado et al. (2002) não verificaram influencia no potencial de água na folha ao amanhecer nos meses de janeiro, março e julho (verão-inverno). De qualquer maneira, faz-se necessário, novas pesquisas que possam explicar melhor a questão. Durante o período experimental, grandes variações foram observadas especialmente no $\Psi_{M}$ em ambos tratamentos, que provavelmente refletiram as condições climáticas como verificado em outros estudos (Scholander et al., 1965; Southwick \& Davenport, 1987; Domingo et al., 1996 e Jones, 2004).

O potencial de água na folha relativo no amanhecer $\left(\Psi_{P-X} / \Psi_{P-Y}\right)$ decresceu quando a $A D$ estava abaixo de $60 \%$ (Figura 7B), concordando com resultado obtido para trocas gasosas. Syvertsen (1982) relata que há uma relação direta entre a diminuição do potencial de água na folha e o fechamento estomático. Entretanto, o potencial de água relativo ao meio-dia ( $\left.\Psi_{M-X} / \Psi_{M-Y}\right)$ não foi sensível ao esgotamento de $A D$ (Figura 7D), permanecendo praticamente constante e variando entre 0,9 e 1,0. Alguns estudos sugerem valores mínimos de potencial da água ao amanhecer como o melhor indicativo para iniciar as irrigações do que as medidas feitas ao meio-dia (Shalhevet \& Levy, 1990; Ginestar \& Castel, 1996; Urribarrí et al., 1996; Domingo et al., 1996 e GonzálezAltozano \& Castel, 2000a). Na realidade, os tecidos da plantas estão hidratados ao máximo pouco antes do amanhecer quando não há restrição hídrica ao passo que as medidas feitas ao longo do dia são realizadas sob ocorrência da transpiração, consumindo mais nitrogênio e são mais susceptíveis as variações no clima, como radiação incidente, temperatura do ar e déficit de pressão de saturação do ar (Figura 7C). 

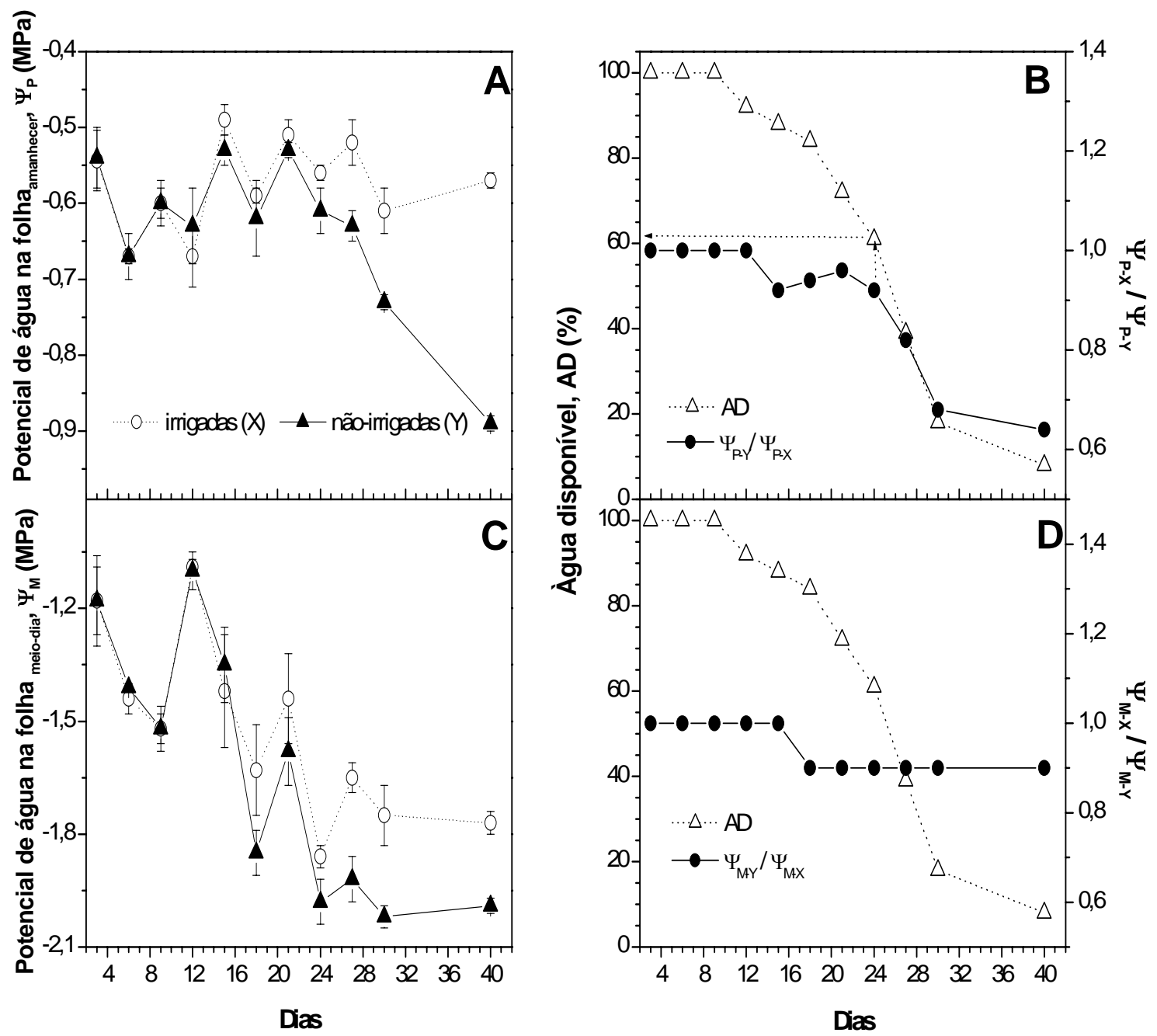

Figura 7 - Potencial de água na folha medido ao amanhecer (A) e ao meio-dia (C) em plantas irrigadas $(X)$ e não-irrigadas $(Y)$ durante o esgotamento da água disponível no solo $(A D)$. Relação entre o potencial relativo da água na folha $(X / Y)$ medido ao amanhecer (B) e ao meio-dia (D) e $A D$. Cada ponto representa o valor médio de seis repetições $( \pm$ SE) 


\subsection{Conclusões}

A evapotranspiração, trocas gasosas e potencial da água na folha ao amanhecer foram diminuídos pelo esgotamento de $40 \%$ da água disponível do solo em condições de campo e no final do período do inverno. No momento em que água disponível estava ao redor de 60\%, o valor observado para o potencial de água na folha era de -0,62 MPa. 


\section{RESPOSTAS DE LIMEIRA ÁCIDA 'TAHITI' A SUPRESSÃO DA IRRIGAÇÃO DURANTE DIFERENTES PERÍODOS FENOLÓGICOS}

\section{Resumo}

Com o objetivo de avaliar as respostas de plantas de limeira ácida 'Tahiti' (Citrus latifolia Tanaka) submetidas à supressão da irrigação em diferentes períodos fenológicos, um experimento foi conduzido em um pomar de 1 ha irrigado por gotejamento localizado no Departamento de Engenharia Rural da Escola Superior de Agricultura - ESALQ, em Piracicaba, SP. O delineamento experimental foi em blocos casualizados com cinco repetições e os seguintes tratamentos (T): $T 1$ (controle), irrigação diária com reposição em $100 \%$ da evapotranspiração do lisímetro do dia anterior; $T 2$, corte da irrigação no florescimento; $T 3$, corte da irrigação no período de formação dos frutos (maioria dos frutos menores que $25 \mathrm{~mm}$ de diâmetro); $T 4$, corte da irrigação no período de maturação dos frutos (maioria dos frutos maiores que $25 \mathrm{~mm}$ de diâmetro); $T 5$, corte da irrigação no florescimento + período de formação dos frutos; $T 6$, corte da irrigação no período de formação + maturação dos frutos; $T 7$, não irrigado em todos os períodos. Antes e após o período de supressão as plantas foram irrigadas da mesma maneira que as do controle. O potencial matricial do solo foi monitorado com base em tensiômetros instalados a 0,3, 0,6 e 0,9 m de profundidade. Foram avaliados o potencial de água na folha, o crescimento dos ramos e frutos, queda de frutos, a produtividade e qualidade dos frutos. Observou-se que a supressão hídrica nos tratamentos promoveu a diminuição do potencial matricial do solo, entretanto apenas afetou significativamente o potencial de água na folha nas plantas não-irrigadas, ainda que promovendo um estresse leve (-0,6 MPa). O desenvolvimento vegetativo, 
reprodutivo e a qualidade dos frutos de limeira ácida não foram afetados negativamente pela supressão da irrigação em qualquer período fenológico.

\section{Summary}

Aiming to evaluate the responses of 'Tahiti' acid lime trees (Citrus latifolia Tanaka) under irrigation suppression in different phenological an experiment was carried out in a 1 hectare drip irrigated orchard localized at Agricultural Engineering Department of College of Agriculture Luiz de Queiroz - ESALQ in Piracicaba, SP. The design experimental was in randomized blocks with five replications with following treatments (T): $T 1$ (control), daily irrigated aiming to replenish 100\% of lysimeter evapotranspiration of previous day; $T 2$, interruption of irrigation on flowering; $T 3$, interruption of irrigation on fruit development (most of diameter fruits smaller than 25 $\mathrm{mm}$ ); $T 4$, interruption of irrigation on fruit maturation (most of diameter fruits bigger than $25 \mathrm{~mm}$ ); $T 5$, interruption of irrigation on flowering + fruit development; $T 6$, interruption on development + fruit maturation; $T 7$, non-irrigated during all phenological periods. Before and after each interruption, trees were irrigated like those of the control. The matric soil potential was monitored by tensiometers at $0.3,0.6$ and $0.9 \mathrm{~m}$ depth. Were evaluated the leaf water potential, shoot and fruit elongation, fruit drop, yield and fruit quality. It was observed that water suppression decreased the matric soil potential, however, affecting only the leaf water potential in non-irrigated trees by promoting a light stress (-0.6 MPa). The vegetative and reproductive development and the fruit quality were not negatively affected by suppression of irrigation in any phenological period.

\subsection{Introdução}

No Estado de São Paulo, maior produtor nacional de citros, até pouco tempo o interesse pelo citricultor em optar pela irrigação era pequeno, pois se conseguia a viabilidade econômica da cultura mesmo sob baixa produtividade (Zanini \& Pavani, 1998). No entanto, com a queda nos preços e a utilização de porta-enxertos menos 
tolerantes ao déficit hídrico, a procura pela utilização da irrigação se tornou crescente nos últimos anos. Concomitantemente, tem havido uma maior busca pela racionalização do recurso hídrico visando permitir a convivência dos usos múltiplos tornando-se, portanto, imprescindível o aumento da eficiência da irrigação.

Basicamente, duas estratégias têm sido propostas para aumento da eficiência da irrigação, a primeira tem sido a opção pela irrigação localizada (microaspersão e gotejamento) possibilitando a redução do volume de água aplicado em comparação com aspersão convencional e a segunda propõe a redução ou supressão da irrigação durante estádios de desenvolvimento menos sensíveis à deficiência hídrica, economizando água com mínimos efeitos sobre a produtividade.

O efeito do estresse hídrico depende da variedade, do grau de duração e do estádio fenológico da planta, podendo trazer resultados tanto negativos quanto positivos, conforme revisão feita por Ginestar \& Castel (1996). No primeiro caso, Castel \& Buj (1992) encontraram que plantas jovens de 'Clementina', na Espanha, tiveram a sua produtividade afetada pelos tratamentos com maiores déficits para cada período do ano e que o período mais sensível foi durante o florescimento e formação dos frutos, concordando com Doorenbos \& Kassam (1994). Como efeitos benéficos, Southwick \& Davenport (1987) mostraram que a floração em lima ácida 'Tahiti' pode ser induzida visando uma produção fora de época, bem como, intensificada, através de um período curto de estresse hídrico, seguido de condições favoráveis para o crescimento e desenvolvimento dos frutos. Torrecillas et al. (1993) não encontraram efeitos negativos na produtividade do limão sob déficit hídrico na fase de rápido crescimento do fruto. A irrigação neste caso deve ser conduzida de forma a favorecer um déficit hídrico controlado, conhecendo-se muito bem o limite de água disponível permissível no solo.

A irrigação dos citros, para as condições climáticas paulistas, tem caráter complementar, o que torna o manejo das indispensáveis (Pires, 1992). No entanto, ainda são escassos os trabalhos realizados sobre o tema na região, em especial, quando se considera a irrigação por gotejamento e em condições de campo. 
O objetivo deste trabalho foi determinar o efeito da supressão hídrica durante diferentes estádios fenológicos via supressão da irrigação avaliando o potencial da água na folha, crescimento dos ramos e frutos pegamento, produtividade e qualidade do fruto, em plantas de limeira ácida 'Tahiti’irrigadas por gotejamento.

\subsection{Material e Métodos}

O experimento foi realizado na Fazenda Areão da Escola Superior de Agricultura

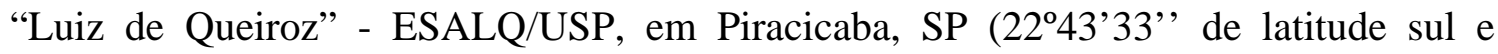
47038'0' de longitude oeste com uma altitude de $511 \mathrm{~m}$ ). A temperatura média anual é de $21,4^{\circ} \mathrm{C}$, e o total anual de chuva é de $1257 \mathrm{~mm}$. O solo da área experimental é classificado como Nitossolo vermelho segundo a classificação brasileira de solos (Embrapa, 1999). A capacidade de água disponível no solo foi de $125 \mathrm{~mm} \mathrm{~m}^{-1}$ para uma densidade média do solo de $1300 \mathrm{~kg} \mathrm{~m}^{-3}$.

As limeiras ácidas 'Tahiti' (Citrus latifolia Tanaka), enxertadas sobre plantas de citrumeleiro 'Swingle' [Poncirus trifoliata (L.) Raf. x Citrus paradisi Macf.], foram plantadas em sulcos na primeira quinzena de maio de 2001 no espaçamento 7x4m, em uma área experimental de aproximadamente 1 ha, sendo a calagem e adubação realizadas de acordo com Raij et al. (1992). Os tratos culturais consistiram de pulverizações com defensivos e roçagens.

O sistema de irrigação utilizado no pomar foi por gotejamento, com 4 emissores autocompensantes por planta e vazão unitária de $4 \mathrm{~L} \mathrm{~h}^{-1}$. Antes do início do experimento foi feita uma avaliação da uniformidade de aplicação da água (CUC) do sistema, seguindo a metodologia detalhada por Zocoler (2003) e os resultados mostraram que foi de 93,4\%. A irrigação foi programada diariamente por um controlador eletrônico e válvulas hidráulicas. Em dias com precipitação maior que $10 \mathrm{~mm}$ a irrigação foi cancelada.

No centro da área constava um lisímetro de pesagem eletrônica com 4 m de diâmetro e 1,3 m de profundidade, com uma exatidão de 0,82 kg para a determinação da 
evapotranspiração da cultura $(E T c)$. Maiores informações podem ser obtidas em Campeche (2002) no qual detalha os procedimento de construção e aferição deste lisímetro. A ETc foi determinada segundo a diferença nas leituras instantâneas da massa (kg) do lisímetro entre um dia e outro, descontados os valores de chuva, irrigações e drenagens, registradas por um sistema automático de coleta de dados "data logger" (modelo CR 23x Campbell Scientific ${ }^{1}$, Logan, UT, EUA) às $2400 \mathrm{~h}$.

Os valores em quilograma foram convertidos em milímetros de água considerando a área do total do espaçamento $\left(28 \mathrm{~m}^{2}\right)$, porém acrescentando a evaporação do solo ( $\mathrm{kg}$ ) correspondente à diferença de área entre o espaçamento da cultura e lisímetro $(15,44$ $\mathrm{m}^{2}$ ). Para tanto, foi utilizado um segundo lisímetro de pesagem eletrônica presente na área, sem planta e sem cobertura vegetal, com dimensões de 1,6 m de diâmetro e 0,7 m de profundidade, com exatidão de 0,156 kg.

O experimento foi instalado em blocos casualizados com 6 tratamentos e cinco repetições, sendo que cada parcela experimental composta por uma planta. Os tratamentos aplicados foram: Tratamento $1(T 1)$, controle (irrigação diária baseada na reposição de 100\% da ETc); Tratamento 2 (T2), corte da irrigação no florescimento; Tratamento 3 (T3), corte da irrigação no período de formação dos frutos (maioria dos frutos menores que $25 \mathrm{~mm}$ de diâmetro); Tratamento 4 (T4), corte da irrigação no período de maturação dos frutos (maioria dos frutos maiores que $25 \mathrm{~mm}$ de diâmetro); Tratamento 5 (T5), corte da irrigação no florescimento + período de formação dos frutos;Tratamento 6 (T6), corte da irrigação no período de formação + maturação dos frutos e Tratamento 7 (T7), não irrigados. Antes e após o período de supressão as plantas de cada tratamento foram irrigadas conforme o Tratamento 1 (Controle). Os resultados foram submetidos a analise da variância com comparação das médias em relação ao tratamento controle pelo teste de Dunnett $(\mathrm{p}<0,05)$.

\footnotetext{
${ }^{1}$ Referências à marca registrada não constituem endosso por parte do autor.
} 
Antes do início do experimento retiraram-se todas as flores e frutas presentes. A irrigação também foi suspensa até o limite médio de -1,0 MPa no potencial de água da folha, medido ao amanhecer, para todos os tratamentos com a finalidade de uniformizar as plantas e estimular a indução floral. O início da brotação foi provocado por uma irrigação interrupta de 20 horas.

Durante o período de estresse hídrico, semanalmente foram realizadas leituras do potencial da água na folha ( $\Psi p$ ) às 05:45-06:15 h (amanhecer, hora local) utilizando uma câmara (modelo 3005, Soil Moisture Equipament Corporation ${ }^{1}$, Santa Bárbara, CA, EUA). O $\Psi p$ foi medido em uma brotação completamente expandida por parcela, contendo de 4 a 8 folhas, localizada no lado Oeste da copa das plantas.

O potencial mátrico no solo ( $\left.\Psi_{s}\right)$ foi determinado a cada 2-3 dias com tensiômetros a 0,3 e 0,6 e 0,9 m de profundidade, em três repetições por tratamento. As leituras foram feitas procurando manter sempre o mesmo horário.

O acompanhamento fenológico foi feito considerando os seguintes períodos: florescimento $(F L)$, chumbinho $(C H)$, maturação dos frutos $(M)$ e Colheita $(C O)$, conforme ilustrado na Figura 1. Em cada fluxo de brotação, foram medidos os comprimentos de dez brotações vegetativas, escolhidas de forma aleatória, por planta. Além disso, determinou-se o somatório de graus-dia $(G D)$ em cada período fenológico, usando a metodologia proposta por Pereira et al. (2002) para uma temperatura basal de $13^{\circ} \mathrm{C}$ (Koller, 1994).

A partir do florescimento, semanalmente, foi contabilizado o número de frutos caídos em cada planta, através de caixas do tipo 'Fruteira', forrada com uma tela plástica, para evitar a perda de material vegetal de pequeno tamanho. A dimensão interna era de $(0,51$ x 0,315 $\mathrm{m})$ e foram deixadas no mesmo quadrante da planta. Também foi medido, em 10 frutos por parcela, o diâmetro equatorial do fruto a partir do período de chumbinho até a colheita. 
A estimativa da evapotranspiração de referência (ETo) foi segundo o método de Penman-Monteith parametrizado por Allen et al. (1998) com base nos dados climáticos diários registrados por uma estação agrometeorológica automática, distante $70 \mathrm{~m}$ dos lisímetros, que apresentava sensores de radiação global, líquida, velocidade do vento, temperatura e umidade relativa do ar.
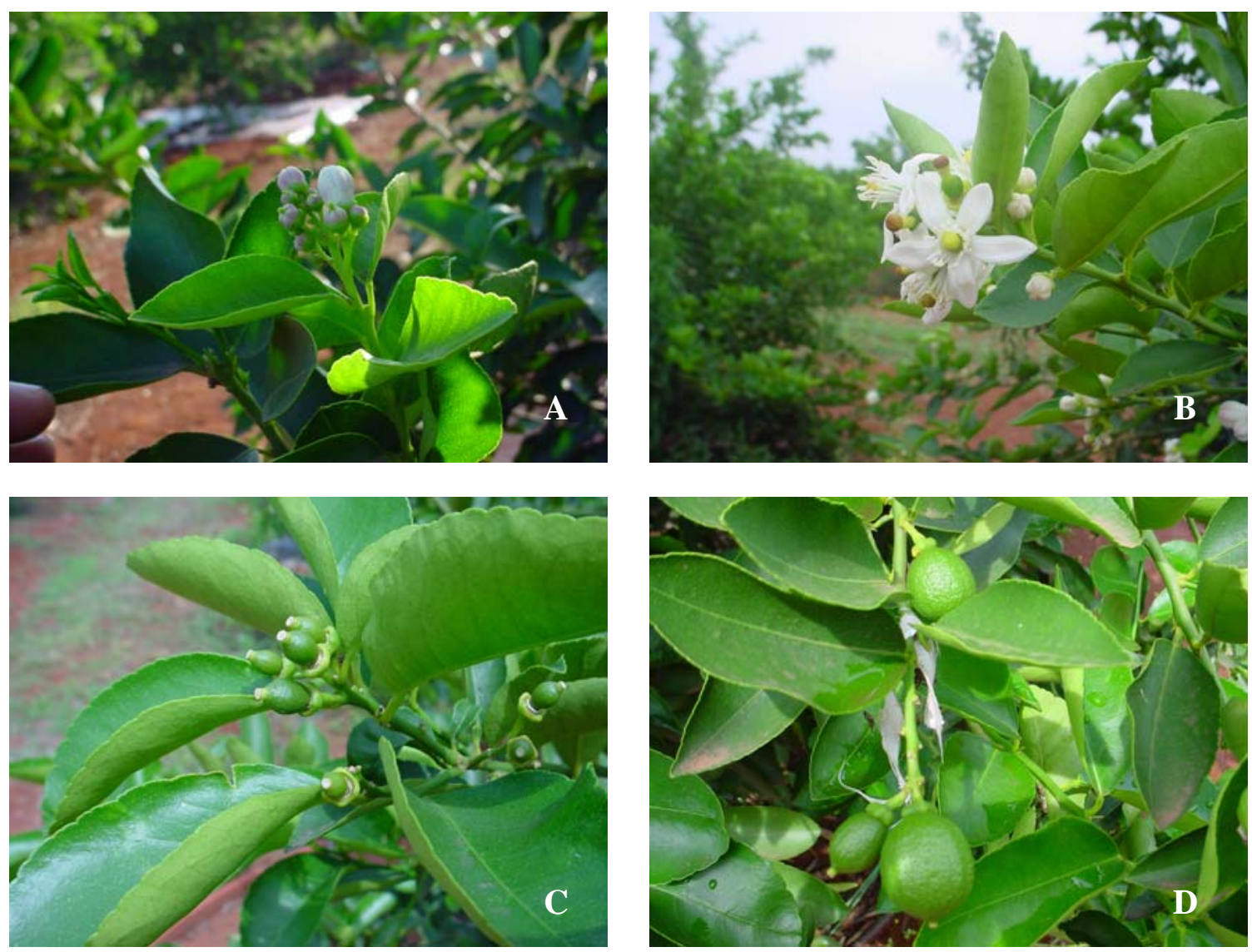

Figura 1 - Fotos ilustrativas dos critérios utilizados para a definição dos períodos fenológicos: A e B-florescimento $(F L)$, C-chumbinho $(\mathrm{CH})$, D-maturação dos frutos $(M)$

A colheita foi realizada quando os frutos atingiram, em média, $50 \mathrm{~mm}$ de diâmetro e foram contados o numero total de frutos por parcela e pesados. Posteriormente, em uma amostra de 10 frutos por parcela, foram medidos os diâmetros transversais na posição perpendicular ao eixo do fruto, assim como medido a espessura da casca com o 
uso de um paquímetro digital, após o corte transversal dos mesmos. Em seguida mediuse o rendimento de suco com a extração mecânica dos 5 frutos, pesando o volume de suco extraído e dividindo-se o mesmo pelo peso dos frutos. Realizou-se ainda, a análise de sólidos solúveis totais (expresso em ${ }^{\circ}$ Brix) com uso de um refratômetro portátil. Para a análise do $\mathrm{pH}$, foi utilizado um potenciômetro digital, com eletrodo de membrana de vidro e por último a acidez total titulável (expressa em porcentagem) segundo técnica recomendada pelo Instituto Adolfo Lutz (1985).

\subsection{Resultados e Discussão}

Irrigação e evapotranspiração

Um resumo dos resultados obtidos quanto à duração dos períodos fenológicos, evapotranspiração e irrigações está presente na Tabela 1. A brotação iniciou-se no dia $13 / 10 / 2004$ e a colheita foi realizada no dia 10/03/2005, totalizando 149 dias e $1658^{\circ} \mathrm{C}$ de somatório térmico ou 1512 graus-dia $(G D)$ da abertura da flor até a colheita, valor muito próximo ao obtido por Souza et al. (2004) com 1493 graus-dia para a mesma espécie.

Embora a precipitação total em cada período tenha sido suficiente no florescimento e muito próxima a $E T c$ no período de chumbinho e maturação dos frutos ocorreram períodos de déficit, totalizando $241,9 \mathrm{~mm}$ para plantas não-irrigadas (T7). Isoladamente, o período fenológico de maior déficit de irrigação correspondeu à maturação dos frutos, totalizando $119 \mathrm{~mm}$, ou 1,95 mm dia ${ }^{-1}$. Esta fase é por muitos autores considerada a menos crítica quando comparada ao florescimento e o pegamento dos frutos (Doorenbos \& Kassam, 1994). Ainda, Vieira (1991) recomenda que a irrigação pode ser interrompida quando os frutos atingirem cerca de 25 a $30 \mathrm{~mm}$ de diâmetro. No entanto, déficits hídricos neste período podem reduzir o crescimento dos ramos, diminuir o tamanho do fruto, aumentar o brix e acidez conforme resultados obtidos por Shalhevet \& Levy (1990), Ginestar \& Castel (1996) e González-Altozano \& Castel (2000a). 
A Evapotranspiração da cultura (ETc) no período total foi de 588,3 mm. A relação entre a $E T c$ e $E T o$, representada pelo coeficiente de cultivo, $K c$ (Allen et al., 1998) foi de 0,9 para o período de florescimento e 1,0 nas fases subseqüentes. A evapotranspiração diária ( $\mathrm{mm} \mathrm{dia}{ }^{-1}$ ) a partir da brotação variou de 2,0 a $7 \mathrm{~mm} \mathrm{dia}^{-1}$, com média de 4,2 mm $\operatorname{dia}^{-1}$.

Tabela 1. Tratamentos (Trat.) aplicados, graus-dia $(G D)$, déficit em irrigação $(D I)$, evapotranspiração da cultura $(E T c)$, evapotranspiração de referência $(E T o)$ e a precipitação pluviométrica $(P)$ em cada período fenológico

\begin{tabular}{ccccccccc}
\hline Trat. & Períodos & Duração & Dias & $\begin{array}{c}\text { GD } \\
{ }^{\circ} \boldsymbol{C}\end{array}$ & $\begin{array}{c}\text { DI } \\
\text { ETo }\end{array}$ & $\begin{array}{c}\text { ETc } \\
(\mathbf{m m})\end{array}$ & P \\
\hline 1 & Controle & & 149 & 1652,0 & - & 608,8 & 588,3 & 676,6 \\
2 & Florescimento-FL & $13 / 10$ a 16/11/04 & 35 & 349,4 & 31,1 & 128,9 & 111,0 & 218,2 \\
3 & Chumbinho-CH & $17 / 11$ a 8/01/05 & 53 & 590,3 & 91,8 & 224,4 & 222,4 & 215,6 \\
4 & Maturação-M & $9 / 01$ a 10/03/05 & 61 & 718,8 & 119,0 & 257,4 & 245,8 & 242,8 \\
5 & FL+CH & $13 / 10$ a 8/01/05 & & & 122,9 & & & \\
6 & CH+M & $17 / 11$ a 10/03/05 & & & 210,8 & & & \\
7 & Sem irrigação & & & & 241,9 & & & \\
\hline
\end{tabular}

Potencial de água na folha e solo

A evolução do potencial de água na folha $(\Psi p)$ nos tratamentos está presente na Figura 1. Pode-se verificar que apenas houveram diferenças significativas, no final de cada período fenológico (florescimento, chumbinho e maturação), entre o $T 7$ (não irrigado) e o $T 1$ (controle). No período de maturação, o $T 6$ (corte da irrigação no período de chumbinho e maturação) também diferiu em relação ao $T 1$. Os valores médios, máximos e mínimos obtidos ao longo do experimento no tratamento $T 1$, foram -0,4,-0,1 e -0,6 MPa. Já para o $T 7$ foram -0,5,-0,1 e -0,6 MPa. De acordo com os resultados comumente reportados na literatura (Shalhevet \& Levy, 1990; Ginestar \& Castel, 1996 e González-Altozano \& Castel, 2000a) para potencial de água na folha em plantas cítricas sob estresse hídrico, pode-se verificar que o nível de estresse foi baixo, mesmo nas plantas não irrigadas (T7). 
As variações ocorridas no $T 1$ provavelmente refletem as mudanças no clima, especialmente o déficit de saturação do vapor do ar conforme verificado em diversos trabalhos (Scholander et al. 1965; Southwick \& Davenport, 1987, Urribarrí et al.,1996 e Jones, 2004).

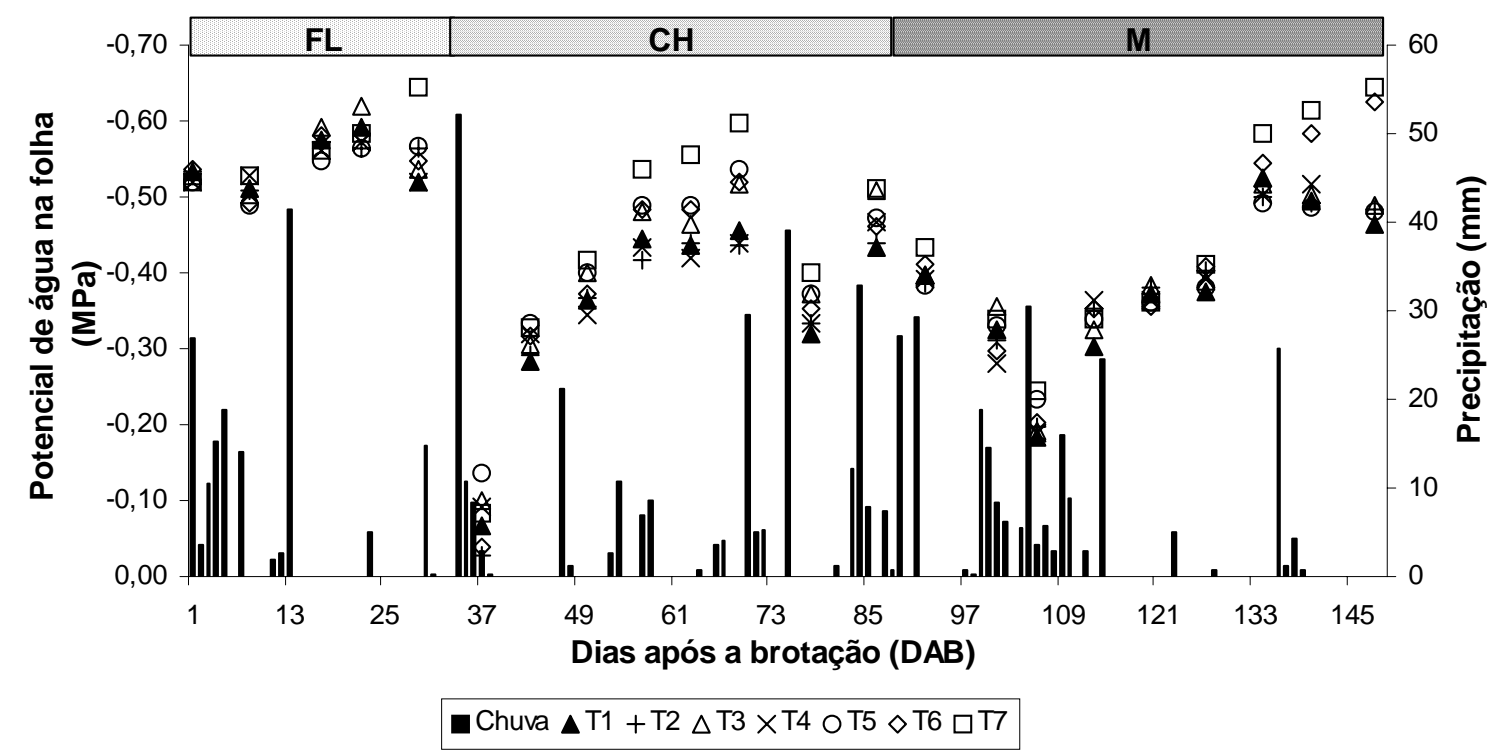

Figura 1 - Evolução do potencial de água na folha nos tratamentos (1 a 7) e precipitação pluviométrica em função do número de dias após a brotação (DAB). Legenda: FL-florescimento, CH-chumbinho e M-maturação

O potencial matricial do solo (valores médios de 0,3, 0,6 e 0,9 m) respondeu a supressão hídrica. Ocorreram diferenças significativas entre os tratamentos em cada período fenológico. No final do período de florescimento, $T 7$ e $T 2$ diferiram em relação ao T1. Já no período de chumbinho, os tratamentos T7, T5, T6 e T3 decresceram rapidamente apesar das precipitações ocorridas no período, apresentando os menores valores de potencial. No final do período de maturação os tratamentos T7, T6 e T4 diferiram significativamente do $T 1$ atingindo potenciais médios de -80 kPa. Pires (1992) cita valores de potencial da água no solo entre -50 a -70 kPa para indicar o momento de irrigar. Medina \& Machado (1998), verificaram que não houve decréscimo na taxa de assimilação de $\mathrm{CO}_{2}$, transpiração, eficiência no uso da água, potencial de água na folha e 
conteúdo relativo de água em laranjeira 'Valência' quando o potencial de água no substrato foi superior a $-40 \mathrm{kPa}$.

Interessante notar que apesar das grandes diferenças verificadas no potencial de água no solo, o potencial de água na folha foi muito semelhante entre os tratamentos, exceto para $T 7$. Jones (2004) comenta que muitas características fisiológicas respondem diretamente a mudanças no status da água na planta melhor do que no conteúdo ou potencial de água no solo, então, o potencial da água na planta além de depender do status da água no solo é influenciado pela taxa que a água flui através da planta, variando em função da demanda evaporativa, concluindo que metodologias baseadas nas respostas da planta melhor do que o status da água no solo, são potencialmente mais precisas para manejo de irrigação.

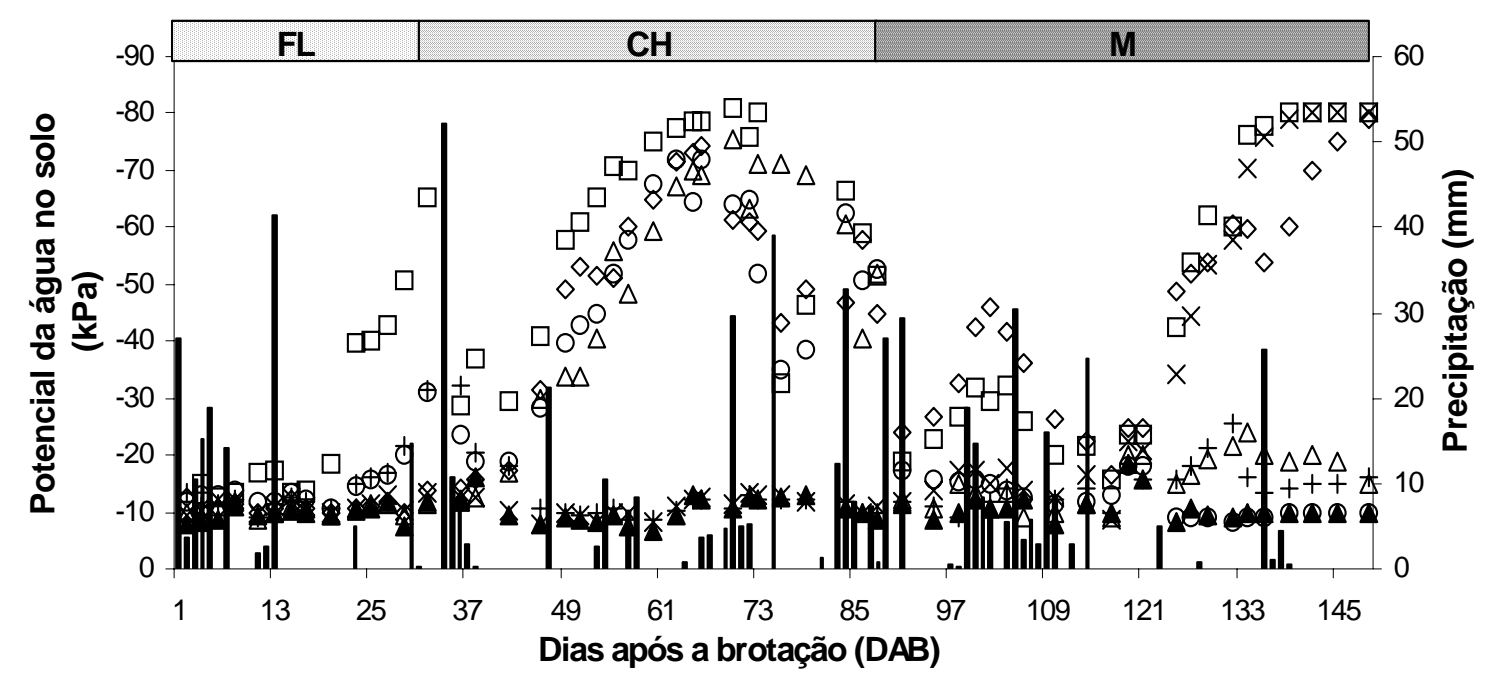

- Chuva $\Delta \mathrm{T} 1+\mathrm{T} 2 \Delta \mathrm{T} 3 \times \mathrm{T} 4$ ○ 5 s $\diamond \mathrm{T} 6 \square \mathrm{T}$

Figura 2 - Evolução do potencial de água no solo nos tratamentos (1 a 7) e precipitação pluviométrica em função do número de dias após a brotação (DAB). Legenda: FL-florescimento, CH-chumbinho e M-maturação 
Desenvolvimento vegetativo

Durante a condução do experimento ocorreram três principais surtos de brotação. Não ocorreram diferenças significativas nos tratamentos no crescimento dos ramos, pegamento e crescimento dos frutos. Apenas para uma descrição fisiológica, serão apresentados os dados referentes aos tratamentos $T 1$ (controle) e T7 (não irrigado).

A Figura 3 ilustra a evolução média do crescimento dos ramos nos três períodos. A partir da brotação a taxa de crescimento é rápida, próxima de $6 \mathrm{~mm} \mathrm{dia}{ }^{-1}$, com um cessamento abrupto após o trigésimo dia. A avaliação semanal do crescimento do fruto foi constante até a colheita, não refletindo um comportamento padrão de curva sigmóide, conforme observado por Marcondes \& Coelho (1991). Segundo Albrigo (1994) apesar do tamanho do fruto ser determinado pelo número de células que são formadas durante o período de divisão celular, uma boa disponibilidade de água no solo durante o desenvolvimento dos frutos pode aumentar a turgescência e conseqüentemente seu tamanho.

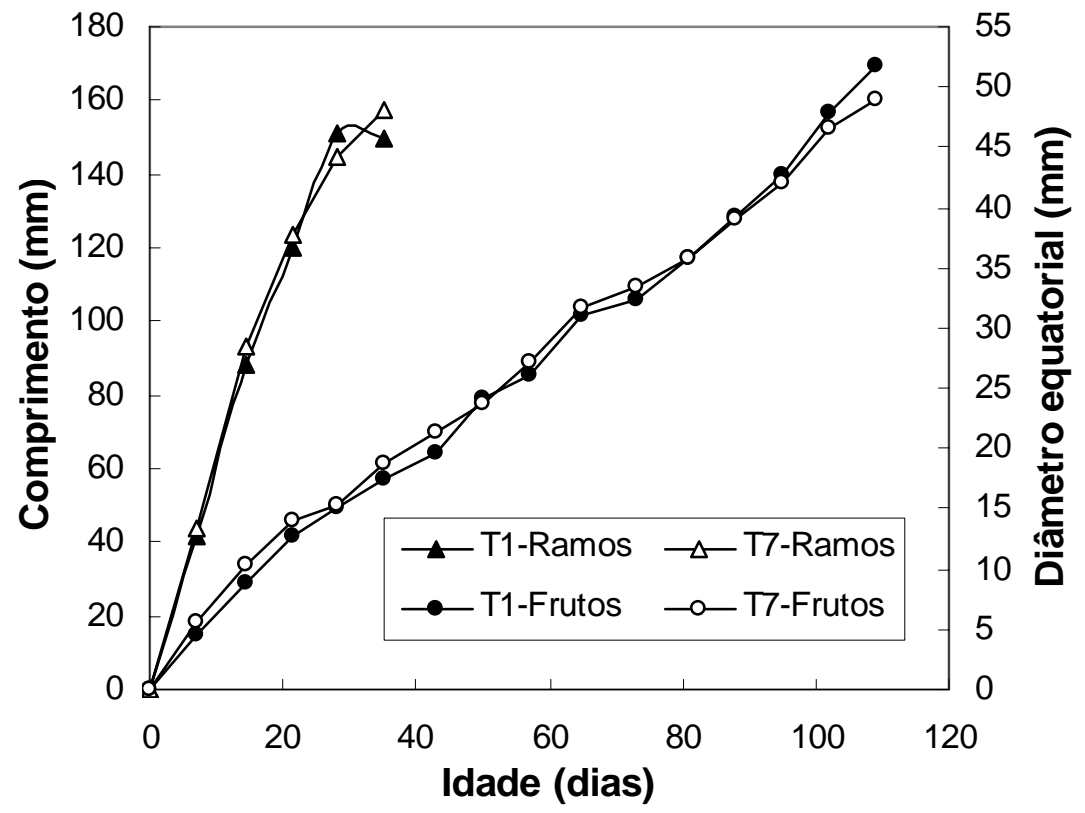

Figura 3 - Evolução do crescimento dos ramos (mm) e diâmetro equatorial do fruto (mm) em função da idade, em dias . Cada ponto representa a média de 50 medidas 
Embora a queda de frutos foi contínua em todos os tratamentos durante o período de avaliação, nota-se um pico, próximo aos 30 dias após a antese (Figura 4). O estresse hídrico, além de outros fatores como a competição dos frutos por carboidratos e água, aumentam a queda fisiológica, principalmente quando os frutos possuem entre 5 a 20 mm de diâmetro. (Davies \& Albrigo, 1994). Ainda que o $T 7$ apresentou o maior número de frutos caídos ao longo período, não ocorreram diferenças estatísticas, provavelmente associada ao alto coeficiente de variação (30\%).

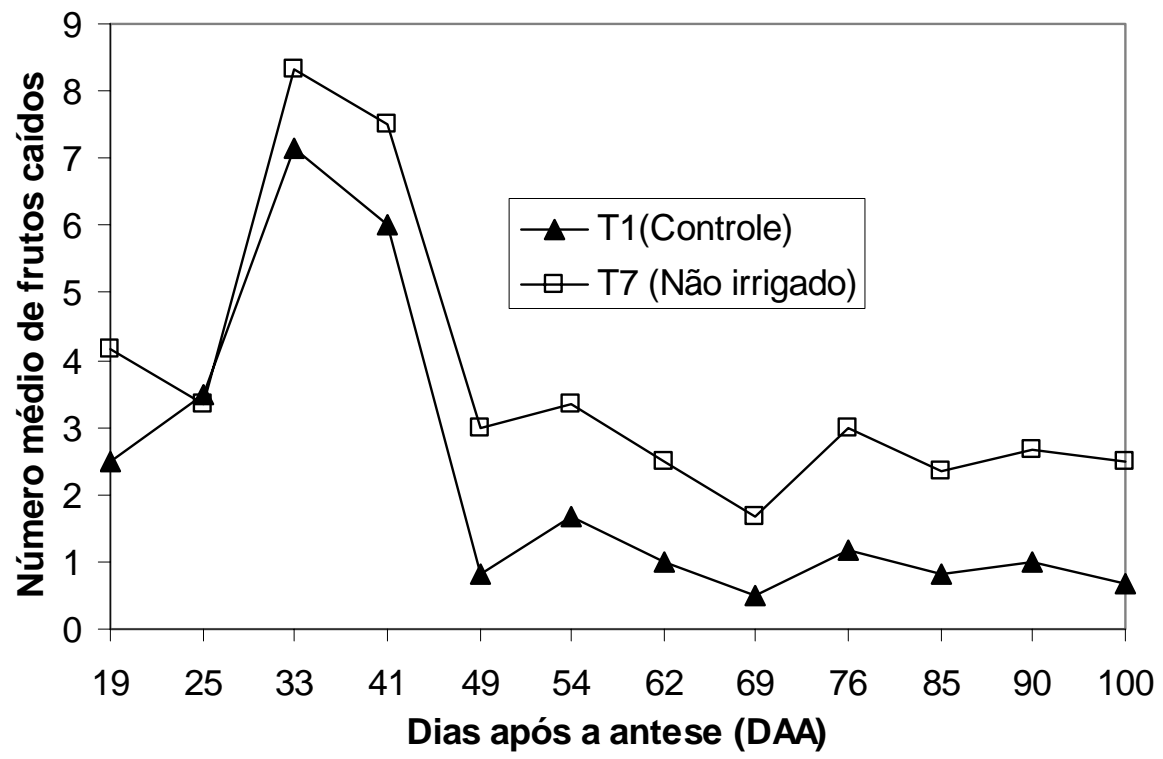

Figura 4 - Número médio de frutos caídos, nos tratamentos $T 1$ e $T 7$, em função do número de dias após a antese (DAA) . Cada ponto representa a média de 5 plantas

\section{Produtividade e qualidade do fruto}

Os resultados referentes à produtividade e qualidade dos frutos se encontram na Tabela 2. Não houve diferença significativa entre os tratamentos. O coeficiente de variação foi alto (>30\%), provavelmente inerente à própria variabilidade genética das plantas no pomar, uma vez que, foram escolhidas plantas de altura e volume de copa semelhante. Um aumento no número de plantas por parcela seria desejável em experimentos futuros para melhorar a confiabilidade dos resultados obtidos. 
Quanto à qualidade do fruto, de uma forma geral, se encontram próximos aos valores comumente encontrados na literatura para a variedade (Gayet et al., 1995 e Souza et al., 2003). Apesar dos resultados não significativos, Shalhevet \& Levy (1990) argumentam que déficits hídricos podem provocar aumento na concentração de açucares e aumentar a acidez do suco. Ginestar \& Castel (1996) verificaram que a supressão hídrica durante o final do período de crescimento do fruto aumentou a espessura da casca, conteúdo de açúcar e acidez e Souza et al. (2003) que verificaram o efeito positivo no aumento do tamanho final dos frutos em limeira ácida tahiti pela irrigação. Provavelmente, o alto potencial de água na folha ao longo do período experimental e também a diferenças varietais contribuiu para o resultado divergente obtido neste trabalho.

Tabela 2. Produtividade e qualidade do fruto e seus respectivos componentes para os diferentes tratamentos ( $T 1$ a $T 7)$

\begin{tabular}{llllllll}
\hline \multicolumn{1}{c}{ Características } & T1 & T2 & T3 & T4 & T5 & T6 & T7 \\
\hline Produtividade(kg planta $^{-1}$ ) & 23,9 & 20,8 & 26,3 & 16,5 & 15,1 & 20,3 & 15,8 \\
Número de frutos planta $^{-1}$ & 343 & 300 & 573 & 248 & 224 & 304 & 241 \\
Diâmetro médio do fruto (mm) & 51,7 & 52,0 & 51,9 & 49,9 & 50,8 & 48,9 & 50,1 \\
Espessura da casca (mm) & 2,8 & 3,0 & 2,8 & 2,6 & 2,8 & 2,6 & 2,6 \\
Suco (\%) & 42,0 & 40,6 & 43,6 & 45,4 & 50,2 & 45,4 & 46,9 \\
Sólidos Solúveis Totais ( ${ }^{\circ}$ Brix) & 8,0 & 8,1 & 8,2 & 8,0 & 8,0 & 8,3 & 8,1 \\
pH & 2,2 & 2,3 & 2,3 & 2,1 & 2,0 & 2,2 & 2,0 \\
Acidez total (\%) & 6,4 & 6,6 & 6,4 & 6,5 & 6,2 & 6,5 & 6,4 \\
\hline
\end{tabular}

\subsection{Conclusões}

A supressão hídrica no período de setembro a março promoveu a diminuição do potencial matricial do solo, atingindo valores de $-80 \mathrm{kPa}$ no perfil de 0 a 0,9 $\mathrm{m}$. No entanto, apenas afetou significativamente o potencial de água na folha nas plantas nãoirrigadas, ainda que promovendo um estresse leve (-0,6 MPa). 
O desenvolvimento vegetativo, reprodutivo e a qualidade dos frutos de limeira ácida não foram afetados negativamente pela supressão da irrigação em qualquer período fenológico possibilitando a economia de água e energia no período. 


\section{CONCLUSÕES GERAIS}

Com base nos resultados obtidos pode-se concluir que:

Verificou-se um efeito sazonal na evapotranspiração $(E T c)$ das plantas de limeira ácida 'Tahiti', com uma redução superior a 50\% para o verão-inverno, possibilitando a economia da irrigação no período;

A evaporação do solo no período noturno deve ser considerada nos cálculos da evapotranspiração, representando 17,4 \% e 13,4\% para o período de inverno e verão respectivamente.

A evapotranspiração, trocas gasosas e potencial da água na folha ao amanhecer foram diminuídos pelo esgotamento de $40 \%$ da água disponível do solo por ocasião do final do período de inverno para as condições climáticas do estado de São Paulo.

A supressão hídrica no período de setembro a março promoveu a diminuição do potencial matricial do solo porém, apenas afetou significativamente o potencial de água na folha nas plantas não-irrigadas, ainda que promovendo um estresse leve (-0,6 MPa) não se observando efeitos negativos no desenvolvimento vegetativo, produtivo e na qualidade dos frutos formados.

Uma vez que o potencial da água na planta depende, principalmente, do status da água no solo, extensão do sistema radicular além da taxa que a água flui através da planta, recomenda-se o potencial da água no folha ao amanhecer para manejo de irrigação, mantendo-o até o limite inferior de -0,6 MPa, para evitar o estresse hídrico em plantas de limeira ácida 'Tahiti'. 


\section{REFERÊNCIAS BIBLIOGRÁFICAS}

ABBOTT, C.E. Blossom-bud differentiation in citrus trees. American Journal of Botany, v.22, p.476-485, 1935.

ALBRIGO, L.G. Effects of foliar applications of urea or nutriphite on flowering and yields of 'Valencia' oranges trees. Proceedings of the Florida State for Horticultural Society, v.112, p1-4, 1999.

ALBRIGO, L.G. Influências ambientais no desenvolvimento dos frutos cítricos. In: SEMINÁRIO INTERNACIONAL DE CITROS, 2., Campinas, 1994. Anais. Campinas: Fundação Cargill, 1994. p.101-105.

ALBRIGO, L.G.; VALIENTE, J.I.; BECK, H.W. Flowering expert system development for a phenology based citrus decision support system. Acta Horticulturae, n.584, p.247-254, 2002.

ALLEN, R.G.; PEREIRA, L.S.; RAES, D. et al. Crop evapotranspiration: guidelines for computing crop water requirements. Rome: FAO, 1998. 300p. (Irrigation and Drainage Paper, 56).

ALVES JÚNIOR, J.; LOURENÇÃO, M.S; SILVA, T.J.A. et al. Distribuição do sistema radicular de plantas jovens de lima ácida 'Tahiti' sob diferentes níveis de irrigação. Irriga, v.9, n.3, p.270-281, 2004.

BERNARDO, S. Manual de irrigação. Viçosa: Imprensa Universitária, 1995. 657p. 
BERTONHA, A.; GONÇALVES, A.C.A.; FREITAS, P.S.L. et al. Resposta de laranjeira Pêra em níveis de irrigação. Acta Scientiarum, v.26, n.2, p.185-191, 2004.

BIELORAI, H. The effect of partial wetting of the root zone on yield and water use efficiently in a drip and sprinkler-irrigated mature grapefruit grove. Irrigation Science, v.3, n.2, p.89-100, 1982.

BOMAN, B.J. Evapotranspiration by young Florida Flatwoods citrus trees. Journal of Irrigation and Drainage, n.120, p.80-88, 1994.

BRAKKE, M.; ALLEN JÚNIOR, L.H. Gas exchange of Citrus seedlings at different temperatures, vapor-pressure deficits, and soil water contents. Journal of the American Society for Horticultural Science, v.120, n.3, p.497-504, 1995.

CAMPECHE, L.F.S.M. Construção, calibração e análise de funcionamento de lisímetros de pesagem para determinação da evapotranspiração da cultura da lima ácida 'Tahiti' (Citrus latifolia Tan.). Piracicaba, 2002. 62p. Tese (Doutorado) - Escola Superior de Agricultura “Luiz de Queiroz”, Universidade de São Paulo.

CASSIN, J.; BOURDEAUT, J.;FOUGUE, F. et al. The influence of climate upon the blooming of citrus in tropical areas. In: INTERNATIONAL CITRUS SYMPOSIUM, 1., Riverside, 1969. Proceedings. Riverside: University of California, 1969. p.315323.

CASTEL, J.R. Response of young clementine citrus trees to drip irrigation. I. Irrigation amount and number of drippers. Journal of Horticultural Science, v.69, n.3, p.481489, 1994.

CASTEL, J.R. Evapotranspiration of a drip-irrigated clementine citrus trees in a weighing lysimeter. Acta Horticulturae, n.449, p.91-98, 1997. 
CASTEL, J.R.; BUJ, A. Response of Salustiana oranges to high frequency deficit irrigation. Irrigation Science, v.11, p.121-127, 1990.

CASTRO, P.R.C; MARINHO, C.S; PAIVA, R. et al. Fisiologia de produção dos citros. Informe Agropecuário, v.22, n.209, p.26-38, 2001.

CHAIKIATTIYOS, S.; MENZEL, C.M.; RASMUSSEN, T.S. Floral induction in tropical fruit trees: effects of temperature and water supply. Journal of Horticultural Science, v.69, n.3, p.397-415, 1994.

CHALMERS, D.J.; MITCHELL, P.D.; VANHEEK, L. Control of peach tree growth and productivity by regulated water supply, tree density and summer pruning. Journal of the American Society for Horticultural Science, v.106, p.307-312, 1981.

CINTRA, F.L.D.; LIBARDI, P.L; SAAD, A.M. Balanço hídrico no solo para portaenxertos de citros em ecossistema de tabuleiro costeiro. Revista Brasileira de Engenharia Agrícola e Ambiental, v.4, n.1, p.23-38, 2000.

COELHO, E.F.; OLIVEIRA, F.C.; ARAÚJO, E.C.E. et al. Distribuição de raízes de laranja "Pêra" sob sequeiro e irrigação por microaspersão em solo arenoso. Pesquisa Agropecuária Brasileira, v.37, n.5, p.603-611, 2002.

CRUZ, A.C.R. Consumo de água por uma cultura de citros cultivada em latossolo vermelho amarelo. Piracicaba, 2003. 92p. Tese (Doutorado) - Escola Superior de Agricultura “Luiz de Queiroz”, Universidade de São Paulo.

DAVENPORT, T.L. Citrus flowering. Horticultural Reviews, v.12, p.249-408, 1990.

DAVIES, F.S.; ALBRIGO, L.G. Citrus. Wallingford: CAB International, 1994. 254 p

DAVIES F.S.; ZALMAN, G.R. Irrigation scheduling and growth of young 'Hamlin' orange trees. Proceedings of the Florida State for Horticultural Society, v.113, p.53-57, 2000. 
DAVIES, W.J.; ZHANG, J. Root signals and the regulation of growth and development of plants in drying soil. Annual Review of Plant Physiology and Plant Molecular Biology, v.42, p.55-76, 1991.

DENMEAD, O.T.; SHAW, R.H. Availability of soil water to plants as affected by soil moisture content and meteorological conditions. Agronomy Journal, v.45, p.385390, 1962.

DOMINGO, R.; RUIZ-SÁNCHEZ, M.C.; SÁNCHEZ-BLANCO, M.J. et al. Water relations, growth and yield of fino lemon trees under regulated deficit irrigation. Irrigation Science, v.16, p.115-123, 1996.

DOORENBOS, J.; KASSAM, A.H. Efeito da água no rendimento dos cultivos. Tradução de H.R. Ghevy et al. Campina Grande: UFPB, 1994. 306 p. (Estudos FAO: Irrigação e Drenagem, 33).

EHRLER, W.L.; BAVEL, C.H.M.Van Leaf difusion resistence, illuminance and transpiration. Plant Physiology, v.43, p.208-214, 1968.

ELFVING, D.C.; KAUFMANN, M.R.; HALL, A.E. Interpreting leaf water potential measurements with a model of soil-plant-atmosphere continuum. Physiologia Plantarum, v.27, p.161-168, 1972.

EMPRESA BRASILEIRA DE PESQUISA AGROPECUÁRIA. Sistema brasileiro de classificação de solos. Brasília: Embrapa Solos, 1999. 412 p.

ERICKSON, L.C.; BRANNAMAN, B.L. Abscission of reproductive structures and leaves of oranges trees. Proceedings of the American Society for Horticultural Science, n.75, p.222-229, 1960.

ERNER, Y.; SHOMER, I. Morphology and anatomy of stems and pedicels of spring flush shoots associated with fruit set. Annals of Botany, v.77, n.5, p.537-545, 1996. 
FARES, A.; ALVA, A. K. Estimation of citrus by soil water mass balance. Soil Science, v.164, n.5, p.302-310, 1999.

FOLEGATTI, M.V; SILVA, T.J.A.; CASARINI, E. O manejo da irrigação como elemento essencial na utilização racional dos recursos hídricos. In: THAME, L.C.M. (Ed.). A cobrança pelo uso da água na agricultura. Embu: IQUAL Editora, 2004. p.213-219.

GAYET, J.P.; BLEINROTH, E.W.; MATALLO, M. et al. Lima ácida 'Tahiti' para exportação: procedimentos de colheita e pós-colheita. Brasília: EMBRAPASPI/FRUPEX, 1995. 36p.

GENUCHTEN, M.van. A closed form equation for predicting the hydraulic conductivity of insaturated soils. Soil Science Society of America Journal, v.41, p.892898,1980 .

GINESTAR, C.; CASTEL, J.R. Responses of Young clementine citrus trees to water stress during different phenological periods. Journal of Horticultural Science, v.71, n.4, p.551-559, 1996.

GOLDSCHMIDT, E.E.; MONSELISE, S.P. Hormonal control of flowering in citrus and some other woody perennial. In: CARR, D.J. (Ed.). Plant growth substances. Berlin: Springler-Verlag, p.758-765, 1970.

GONZÁLEZ-ALTOZANO, P.; CASTEL, J.R. Effects of regulated deficit irrigation on 'Clementina de Nules' citrus trees growth, yield and fruit quality. Acta Horticulturae, n.537, p 749-758, 2000a.

GONZÁLEZ-ALTOZANO, P.; CASTEL, J.R. Regulated deficit irrigation in 'Clementina de Nules' citrus trees. II: Vegetative growth. Journal of Horticultural Science and Biotechnology, v.75 , n.4, p.388-392, 2000b. 
GOREN, R. Anatomical, physiological and hormonal aspects of abscission in citrus. Horticultural Reviews, v.15, p.145-82, 1993.

GREEN, G.C.; BRUWER, W. An improved weighing lysimeter facility for citrus evapotranspiration studies. Water SA, v.5, n.4, p.189-195, 1979.

GREEN, G.C.; CLOTHIER, B.E.; KERR, J.P et al. Evapotranspiration from pasture: a comparation of lysimeter and Bowen ratio measurements with Priestley-Taylor estimates. New Zealand Journal of Agricultural Research, n.27, p.321-327, 1984.

HILGEMAN, R.H. Response of citrus trees to water stress in Arizona. Proceedings of the International Society of Citriculture, v.1, p.70-74, 1977.

HOWELL, T.A.; SCHNEIDER, A.D.; JENSEN, M.E. History of lysimeter design and use for evapotranspiration measurements. In: ALLEN, R.G.; HOWELL, T.A.; PRUITT, W.O. et al. (Ed.). Lysimeter for evapotranspiration and environmental measurements. New York: American Society of Civil Engineers, 1991. p.1-9.

HSIAO, T.C. Growth and productivity of crops in relations to water status. Acta Horticulturae, n.335, p.137-148, 1993.

HUTCHINSON, D.J. Influence of rootstock on the performance of 'Valencia' sweet orange. Procedings of the International Society of Citriculture, n.2, p.523-525, 1977.

INSTITUTO ADOLFO LUTZ. Normas analíticas: métodos químicos e físicos para análise de alimentos. 4. ed. São Paulo: IAL, 1985. 426p.

JACKSON, R.D.; REGINATO, R.J.; IDSO, S.B. Wheat canopy temperature: a pratical tool for evaluating water requirements. Water Resources Research, v.13, p.651656, 1977.

JAHN, O.L. Inflorescence types and fruiting patterns in Hamilin and Valencia oranges and Marsh grapefruit. American Journal of Botany, v.60, p.663-670, 1973. 
JENSEN, M.E. Consumptive use of water and irrigation water requirements. New York: American Society of Civil Engineers, 1973. 215 p.

JONES, H.G. Irrigation scheduling: advantages and pitfalls of plant-based methods. Journal of Experimental Botany, v.55, n.407, p.2427-2436, 2004.

JONES, W.W.; CREE, C.B. Environmental factors related to fruiting of Washington Navel oranges over a 28-year period. Proceedings of the American Society for Horticultural Science, v.85, p.267-281, 1964.

KLEPPER, B. Origin, branching and distribution of root systems. In: GREGORY, P. J.; LAKE, J. V.; ROSE, D. A. Root development and function. New York: Cambridge University Press, 1987. p. 103-123.

KOLLER, O.C. Citricultura: laranja, limão, tangerina. Porto Alegre: Editora Rígel, 1994. 446p.

KRAJEWSKI, A.J.; RABE, E. Citrus flowering: a critical evaluation. Journal of Horticultural Science, v.70, n.3, p.357-374, 1995.

KRIEDEMANN, P.E.; BARRS, H.D. Citrus orchards. In: KOZLOWSKI, T.T. (Ed.). Water deficits and plant growth. New York: Academic press, 1981. v.7, 325-417p.

LEVY, Y.; BIELORAI, H.; SHALHEVET, J. Long-term effects of different irrigation regimes on grapefruit tree development and yield. Journal of the American Society for Horticultural Science. v.103, p.680-683, 1978.

LIU, F.; JENSEN, C.R.; ANDERSEN, M.N. Hydraulic and chemical signals in the control of leaf expansion and stomatal conductance in soybean exposed to drought stress. Functional Plant Biology, v.30, p.65-73, 2003.

LOVATT, C.J. ZHENG, Y.; HAKE, S.D. Demostration of a change in nitrogen metabolism influencing flower initiation in citrus. Israel Journal of Botany, n.37, p.181-188, 1988. 
MACHADO, C.E.; MEDINA, C.L.; GOMES, M.M.A. et al. Variação sazonal da fotossíntese, condutância estomática e potencial da água na folha de laranjeira 'Valência’. Scientia Agricola, v.59, n.1, p.53-58, 2002.

MACHADO, E.C.; MEDINA, C.L.; GOMES, M.M.A. Teor de água no substrato de crescimento e fotossíntese em laranjeira 'Valência'. Bragantia, v.58, n.2, p.217-226, 1999.

MARCONDES, P.T.S.; COELHO, S.Y. Crescimento de fruto de limão 'Tahiti'. Revista Brasileira de Fruticultura, v. 13, n.2, p.203-207, 1991.

MARLER, T.E.; DAVIES, F. Microsprinkler irrigation and growth of young 'Hamlin' orange trees. Journal of the American Society for Horticultural Science, v.115, n.1, p.45-51, 1990.

MEDINA, C.L. Fisiologia da produção. In: MATTOS JÚNIOR, D.; DE NEGRI, J.D.; FIGUEIREDO, J.O (Ed.). Lima ácida Tahiti. Campinas: Instituto Agronômico, 2003. p.13-30.

MEDINA, C.L.; MACHADO, E.C. Trocas gasosas e relações hídricas em laranjeira 'Valência' enxertada sobre limoeiro 'Cravo' e Trifoliata e submetida à deficiência hídrica. Bragantia, v.57, n.1, p.15-22, 1998.

MEDINA, C.L.; MACHADO, E.C.; GOMES, M.M.A. Condutância estomática, transpiração e fotossíntese em laranjeira 'Valência' sob deficiência hídrica. Revista Brasileira de Fisiologia Vegetal, v.11 n.1, p.29-34, 1999.

MEDINA, C.L.; MACHADO, E.C.; PINTO, J.M. Fotossíntese de laranjeira 'Valência' enxertada sobre quatro porta-enxertos e submetida à deficiência hídrica. Bragantia, v.57, n.1, p.1-14, 1998.

MONSELISE, S.P. Citrus and related species. In: HALEVY, A.H. (Ed.). Handbook of flowering. Boca Raton: CRC Press, 1985. v.2, p.275-294. 
MONSELISE, S.P. Citrus. In: MONSELISE, S.P (Ed.). Handbook of fruit set and development. Boca Raton: CRC Press, 1986. p.87-108.

MONSELISE, S.P.; GOLDSCHMIDT, E.E. Alternate bearing in fruit trees. Horticultural Reviews, v.4, p.128-173, 1982.

MONTENEGRO, H.W.S. Contribuição ao estudo do sistema radicular das plantas cítricas. Piracicaba, 1960. 147p. Tese (Cátedra) - Escola Superior de Agricultura “Luiz de Queiroz”, Universidade de São Paulo.

MOREIRA, C.S. Estudo da distribuição do sistema radicular da laranjeira "Pêra" (Citrus sinensis, OSBECK) com diferentes manejos de solo. Piracicaba, 1983. 97p. (Tese Livre-Docência) - Escola Superior de Agricultura “Luiz de Queiroz”, Universidade de São Paulo.

MOSS, G.I. Influence of temperature and photoperiod on flower induction and inflorescence development in sweet orange (Citrus sinensis (L). Osbeck). Journal of Horticultural Science, v.44, p.311-320, 1969.

MOSS, G.I. chemical control of flower development in sweet oranges (Citrus sinensis). Australian Journal of Agricultural Research, v.21, p.233-242, 1970.

MOSS, G.I. Effect of fruit on flowering in relation to biennial bearing in sweet orange (Citrus sinensis). Journal of Horticultural Science, v.46, p177-184, 1971.

MOSS, G.I. Temperature effects on flower initiation in sweet orange (Citrus sinensis). Australian Journal of Agricultural Research, v.27, p.399-407, 1976.

MOSS, G.I.; STEER, B.T.; KRIEDEMANN, P.E. The regulatory role of inflorescences leaves in fruit-setting by sweet orange (Citrus sinensis). Physiologia Plantarum, v.27, p.432-438, 1972. 
MULLIS, M.G.; PLUMMER, J.A.; SNOWBALL, A.M. Flower initiation: new approaches to the study of flowering perennial fruits plants. In: WRIGHT, C.J.(Ed.). Manipulation of fruiting. London: Butterworths, 1989. p.65-77.

NIR, I.; GOREN, R.; LESHEM, B. Effects of water stress, gibberellic acid and CCC on flower differentation in 'Eureka'lemon trees. Journal of the American Society for Horticultural Science. v.97, n.6. p.774-778, 1972.

PARAMASIVAM, S.; ALVA, A.K.; FARES, A. An evaluation of soil water status using tensiometers in a sandy soil profile under citrus production. Soil Science, v.165, n.4, 2000.

PEREIRA, A.R.; ANGELOCCI, L.R.; SENTELHAS, P.C. Agrometeorologia: fundamentos e práticas. Guaíba: Agropecuária, 2002. 478p.

PEREIRA, F.A.C. Desempenho do modelo de Penman-Monteith e de dois evaporímetros na estimativa da evapotranspiração de referência (ETo) em relação a um lisímetro de pesagem. Piracicaba, 1998. 87p. Tese (Doutorado) - Escola Superior de Agricultura “Luiz de Queiroz”, Universidade de são Paulo.

PIRE, R.; ROJAS, E. Effects of drought stress and urea sprays on production of flower and vegetative buds of Tahiti lime. Fruits, v.54, n.3 p.177-182, 1999.

PIRE, R.; BAUTISTA, D.; ROJAS, E. The influence of soil moisture on the vegetative and reproductive growth of orange trees under tropical conditions. Acta Horticulturae, n.335, p.527-534, 1993.

PIRES, R.C.M. Manejo da água na irrigação dos citros. Laranja, v.1, n.13, p.237-260, 1992.

RAIJ, B.van; SILVA, N.M.; BATAGLIA, O.C. et al. Recomendações de adubação e calagem para o Estado de São Paulo. Campinas: Instituto Agronômico, 1992. 107p. (Boletim Técnico 100). 
REICHARDT, K. A água em sistemas agrícolas. São Paulo: Editora Manole, 1990. 188p.

REUTHER, W. Climate and citrus behavior. In: REUTHER, W. (Ed.). Citrus industry. Berkeley: University of California, 1973. v.3, p.280-337.

RODRIGUEZ, O.; INFORZATO, R.; TEÓFILO SOBRINO, J. Estudo do sistema radicular de três porta-enxertos para citros em viveiro. Revista Brasileira de Fruticultura, v.1, n.1, p.23-30,1978.

RUIZ, R.; GUARDIOLA, J.L. Carbohydrate and mineral nutrition of orange fruitlets in relation to growth and abscission. Physiologia Plantarum, v.90, p.27-36, 1994.

RUIZ, R.; GARCÍA-LUIS, A.; MONERRI, C. et al. Carbohydrate availability in relation to fruitlet abscission in citrus. Annals of Botany, v.87, p.805-812, 2001.

SANTOS, D.B; COELHO, E.F; SILVA, T.S.M. et al. Distribuição espacial do sistema radicular do limão ‘Tahiti' enxertado com citrumelo ‘Swingle’ sob microaspersão no semi árido Baiano (compact disc). In: CONGRESSO BRASILEIRO DE ENGENHARIA RURAL, 31., Salvador, 2002. Anais. Jaboticabal: SBEA, 2002.

SAUER, M.R. The growth of orange shoots. Australian Journal of Agricultural Research, v.2 p.105-117, 1951.

SCHOLANDER, P.F.; HAMMEL, H.T.; BRADSTREET, E.D; HEMMINGSEN, E.A. Sap pressure in vascular plants. Science, v.148, p.339-346, 1965.

SEPASKHAH, A.R.; KASHEFIPOUR, S.M. Evapotranspiration and crop coefficient of sweet lime under drip irrigation. Agricultural Water Management, v.27, p.331340, 1995.

SHALHEVET, J.; LEVY, Y. Citrus trees. In: STEWART, B.A.; NIELSEN, D.R. (Ed.). Irrigation of agricultural crops. Madison: American Society of Agronomy, 1990. p.951-986. (Agronomy, 30). 
SHIRGURE, P.S.; MARATHE, R.A.; LALLAN, R.A.M. et al. Irrigation scheduling in acid lime (Citrus aurantifolia) as affected by different soil moisture regimes. Indian Journal of Agricultural Sciences, v.70, n.3, p.173-176, 2000.

SILVA, F.C.; FOLEGATTI, M.V.; MAGIOTTO, S.R. Análise do funcionamento de um lisímetro de pesagem com célula de carga. Revista Brasileira de Agrometeorologia, v. 7, n. 1, p.53-58, 1999.

SMAJSTRLA, A.G; KOO, R.C.J. Effects of trickle irrigation methods and amounts of water applied on citrus yields. Proceedings of the Florida State for Horticultural Society, v.97, p.3-7, 1984.

SMAJSTRLA, A.G.; PARSONS, L.R.; ARIBI, K. et al. Response of Young citrus trees to irrigation. Proceedings of the Florida State for Horticultural Society, v.98, p.25-28, 1985.

SOUTHWICK, S.M.; DAVENPORT, T.L. Modification of water stress-induced floral response in 'Tahiti' lime. Journal of the American Society for Horticultural Science, v.112, n.2, p.231-236, 1987.

SOUZA, C.F.; MATSURA, E.E. Avaliação de sondas de TDR multi-haste segmentadas para estimativa da umidade do solo. Revista Brasileira de Engenharia Agrícola e Ambiental, v.6, n.1, p.63-68, 2002

SOUZA, M.J.H.; RAMOS, M.M.; SIQUEIRA, D.L. et al. Produção e qualidade dos frutos de limeira ácida 'Tahiti’ submetida a diferentes porcentagens de área molhada. Revista Brasileira de Engenharia Agrícola e Ambiental, v.7, p.245-250, 2003.

SOUZA, M.J.H.; RAMOS, M.M.; SIQUEIRA, D.L. et al. Estresse esse hídrico e época de produção da lima ácida 'Tahiti'. Revista Brasileira de Engenharia Agrícola e Ambiental, v.8, n.1, p.31-38, 2004. 
SPIGEL-ROY, P.; GOLDSCHMIDT, E.E. Biology of citrus. London: Cambridge University Press, 1996. 230p.

STRECK, N.A. Do we know how plants sense a drying soil? Ciência Rural, v.34, p.581-584, 2004.

SYVERTSEN, J.P. Minimum leaf water potential and stomatal closure in citrus leaves of different ages. Annals of Botany, v.49, n.6, p.827-834, 1982.

SYVERTSEN, J.P.; ALBRIGO, L.G. Seasonal and diurnal citrus leaf and fruit water relations. Botanical Gazette, v.141, p.440-446, 1980.

SYVERTSEN, J.P.; LLOYD, J.J. Citrus. In: SCHAFFER, B.; ANDERSON, P.C. (Ed.). Handbook of environmental physiology of fruit crops: sub-tropical and tropical crops. Boca Raton: CRC Press,1994. v.2, p.65-99.

SYVERTSEN, J.P.; SMITH JUNIOR, M.L.; ALLEN, J.C. Growth rate and water relations of citrus leaf flushes. Annals of Botany, v.47, p.97-105, 1981.

TAIZ, L.; ZEIGER, E. Fisiologia vegetal. 3.ed. Trad. de E. R. Santarém et al. Porto Alegre: Artmed, 2004. 719p.

TALÓN, M.; TADEO, F.R.; BEN-CHEIKH, W. et al. Hormonal regulation of fruit set and abscission in citrus: classical concepts and new evidence. Acta Horticulturae, n.463, p.209-217, 1997.

TAMIN, M.; ALTMAN, R.G.; GOLDSCHMIDT, E.E. Modification of time and intensity of flowering in citrus cultivars by water stress, light, low temperature and growth regulators. In: INTERNATIONAL CITRUS CONGRESS, 8., Sun City, 1996. Nelspruit: International Society of Citriculture, 1997. v.2, p.845-848.

TOMMASELLI, J.T.G; BACCHI, O.O.S. Calibração de um equipamento de TDR para medida de umidade dos solos. Pesquisa Agropecuária Brasileira, v.36, n.9, p.1145-1154, 2001. 
TORRECILLAS, A.; RUIZ-SÁNCHEZ, M.C; DOMINGO, R. et al. Regulated deficit irrigation on fino lemon trees. Acta Horticulturae, n.335, p.205-212, 1993.

URRIBARRÍ, L.L.; FRANCISCO ARAUJO, B.; VILLALOBOS, R. Una metodología para la estimación del estrés hídrico en plantas de lima 'tahití' (citrus x 'tahití'). Revista de la Faculdad de Agronomía, v.13, n.1, p.49-60, 1996.

VALIENTE, J.I.; ALBRIGO, G. Flower bud induction of sweet orange trees [Citrus sinensis (L) Osbeck]: effect of low temperatures, crop load, and bud age. Journal of the American Society for Horticultural Science, v.129, n.2, p.158-164, 2004.

VERMEIREN, L.; JOBLING, G.A. Irrigação localizada. Trad. de H.R Gheyi et al. Campina Grande: UFPB, 1997, 184p. (Estudos FAO: Irrigação e Drenagem, 36).

VIEIRA, D.B.; RIBEIRO, T.A.P. Estudo de parâmetros básicos de irrigação do limão Tahiti (Citrus limonia OSBECK) sob micro-aspersão. In: CONGRESSO BRASILEIRO DE ENGENHARIA AGRÍCOLA,19., Ilhéus, 1993. Anais. Jaboticabal: SBEA, 1993. v.4, p.2328-2339.

VOLPE, C.A. Fenologia dos citros. In: SEMINÁRIO INTERNACIONAL DE CITROS: FISIOLOGIA, 2., Bebedouro, 1992. Anais. Campinas: Fundação Cargill. 1992. p.107-121.

VU, J.C.V.; YELENOSKY, G. Water deficit and associated changes in some photosynthetic parameters in leaves of 'Valencia' orange (Citrus sinensis [L.] Osbeck). Plant Physiology, v.88, p.375-378, 1988.

WONG, S.C.; COWAN, I.R.; FARQUHAR, G.D. Stomatal conductance correlates with photosynthetic capacity. Nature, v.282, p.424-426, 1979.

YANG, L. S.; YANO, T.M.A; LI, X. Evapotranspiration of orange trees in greenhouse lysimeters. Irrigation Science, n.21, p.145-149, 2003. 
ZANINI, J.R.; PAVANI, L.C. Irrigação em citros. In: SEMINÁRIO INTERNACIONAL DE CITROS: TRATOS CULTURAIS. Campinas: Fundação Cargill, 1998. p.409-442.

ZOCOLER, J.L. Avaliação de desempenho de sistemas de irrigação. http://www.agr.feis.unesp.br/curso5.htm. (20 ago. 2003). 